\title{
AFEHANLSTAN FDRUM
}

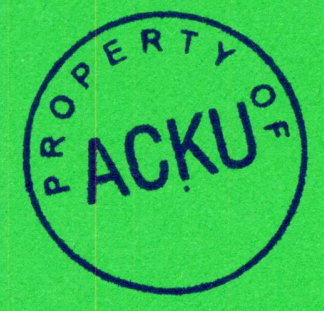

EDNTENTS

VQL. $\times \times V$

NE. 2

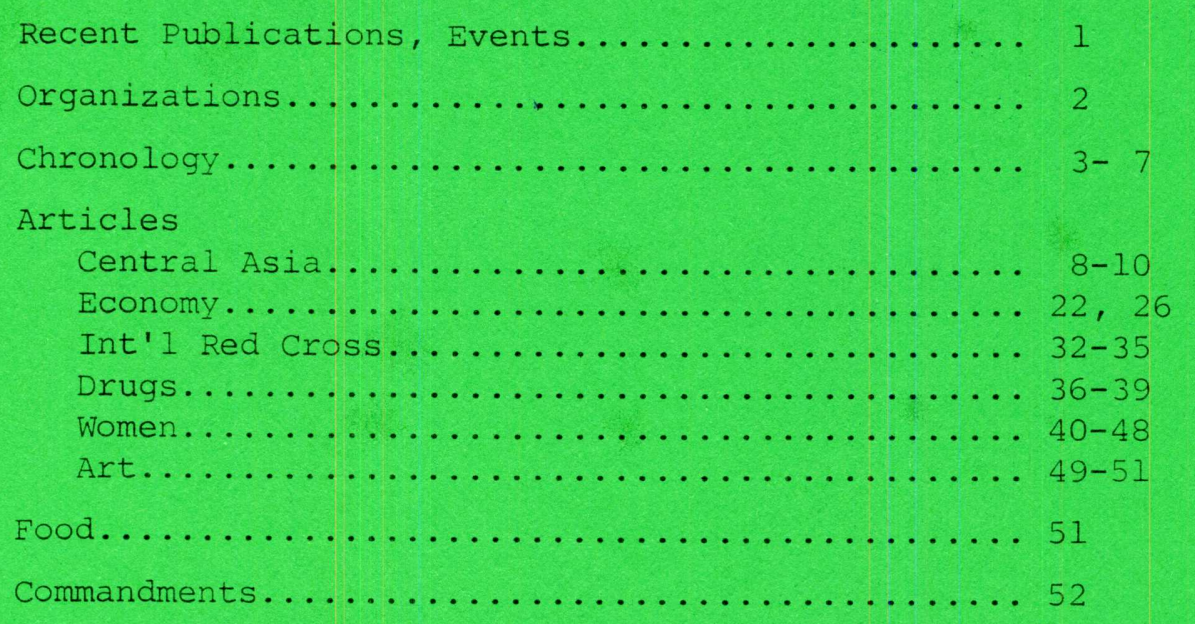

THE AFGHANISTAN FORUM, INC.

19 Fanning Avenue East Hampton, NY 11937 


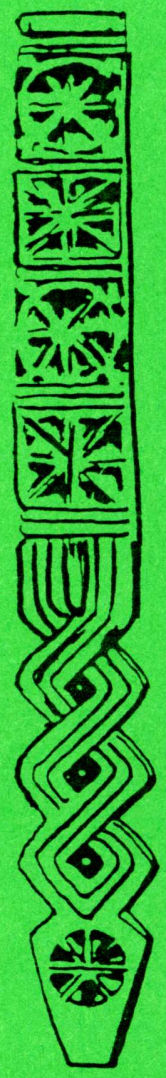

ACBAR - Agency Coordinating Bureau for Afghan Relief

AFP - Agence France Presse

ARIC - Afghan Resource \& Information Center

BIA - Bakhtar Information Agency

CSM - Christian Science Monitor

FBIS - Foreign Broadcast Information Service

FRG - Federal Republic of Germany

ICRC - Int'1 Committee of the Red Cross

LAT - Los Angeles Times

NGO - Non-Governmental Organization

NWFP - Northwest Frontier Province

NYT - New York Times

OIC - Organization of Islamic Conference

PCV - Peace Corps Volunteer

PT - Pakistan Times

PVO - Private Voluntary Organization

UNGA - United Nations General Assembly

UNOCA - United Nations Office of the Commissioner for Afghanistan (sometimes UNOCHA)

UNHCR - United Nations High Commission for Refugees

USAID - United States Agency for Int'1 Development

WP - Washington Post

WSJ - Wa11 Street Journal

Please send items for the AFGHANISTAN FORUM to The Afghanistan Forum

19 Fanning Avenue

East Hampton, NY 11937

The opinions expressed in the FORUM are those of the parties \& publications involved \& are not necessarily those of the Afghanistan FORUM. Listing of organizations does not necessarily imply endorsement.

Mary Ann Siegfried

Editor \& Typist
Leonard Oppenheim

Treasurer \& Proofreader

Book Review Editors

Rosanne Klass

Rhea Talley Stewart

Subscription rates:

4 . issues/year

$\$ 25$ per year (US \& Canada)

$\$ 25$ per year (US \& Canada) (Add \$5 for FORUM PAPERS)

$\$ 25$ per year (foreign); airmai

$\$ 35$ per year (institutions)

(includes FORUM PAPERS)

$\$ 45$

$\$ 40$

$\$ 50$

ISSN : $0889-2148$ 
From the Editor:

Even though the editor is a computer illiterate, she knows that out there in the Web World there is lots of information about Afghanistan. Thanks to many of you, samples from it are squeezed into the pages of this issue \& there are some treasures left over for the next one. We hope in the near future to have some sort of annotated guide to web sites that have information about Afghanistan. We would appreciate receiving information that our surfer readers have...in non-technical language so that the editor can understand it!

At long last, the Taliban Occasional Paper is ready \& will be sent to everyone who ordered it with last year's subscription. If you didn't order it but would like it, copies are $\$ 8$ each, including postage.

Speaking of Taliban, the proofreader wishes to remind you that we spell names as they appear in the article cited. Inconsistencies are not his fault.

Again, our thanks to everyone who sent us information. Because of your support we have an issue full of all kinds of material on all kinds of subjects. Please keep sending. The deadline for the next issue is JuIy 31.

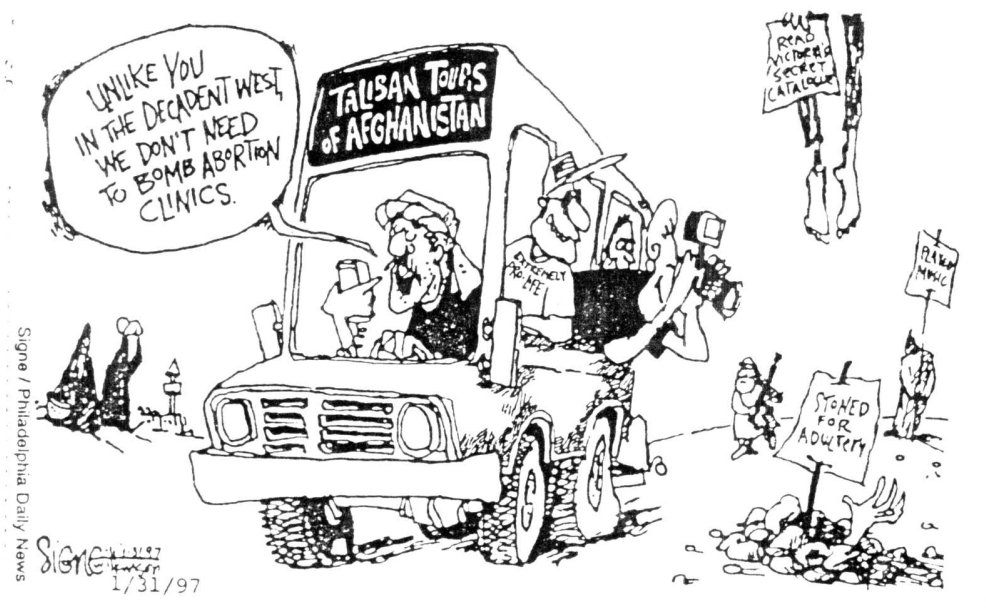

\section{REEENT PUBLIEATIONS}

TRADITIONAL TEXTILES OF CENTRAL ASIA bY Janet Harvey, Thames \& Hudson, 1996. Paperback edition, 1997. \$24.95. 262 illus. 2 maps.

IMAGERIES POPULAIRES EN ISLAM by Pierre Centlivres \& Micheline Centlivres-Demont, Georg Editeur SA, 46, Chemin de la Mousse, CH-1225, Chene-Bourg, Switzerland.

108 pp., 100 color illus. 39 Swiss fr. + postage.

LA NOUVELIE ASIA CENTRALE ou La Fabrication des nations by Olivier Roy, Editions du Seuil, 27, rue Jacob, Paris VIe, France. 332 pp. Paper. 140 Fr. fr. 1997

HISTOIRE DE LA GUERRE D'AFGHANISTAN bY Assem Akram, Editions Balland, Paris, 1996. 636 pp., maps, glossary, chronology. $240 \mathrm{Ff}$.

Not new, but nice - HORSEMEN OF AFGHANISTAN by Roland \& Sabrina Michaud, Thames \& Hudson, 1988. 103 color photos of buzkashi. (Copies were available at The Asia Society bookstore, 725 Park Ave., New York, NY 10021 for $\$ 35$. )

\section{EOENTS}

The University of Pennsylvania's Museum of Anthropology will display Luke Powell's photographs of Afghanistan from April

26 to August 23. The Museum is at $33 \mathrm{rd}$ \& Spruce Streets in Philadelphia. Notecards made from the photographs are available and might make good fund raising items. For information, contact Luke Powell at 230 Battery Block, Middlebury, VT 05753 or email: luke@ sover.net. His internet site is: http://www. lukepowell. com, .

\section{F」LII}

A DREAM OF KABUL, a documentary by Wilma Kiener \& Dieter Matzka (Betacam SP/80 minutes) about the 100,000 flower-children who came to Kabul to make love not war. The film team went back to Kabul 20 years later to find the city in ruins. "The Kabul of the flower children lives only in their memories." VHS cassette, DM 39.95 + postage from Matzka-kienerFilmproduction, Bereitranger 3, D-81541 Munich. email: Matzkakiener acompuserve. com 


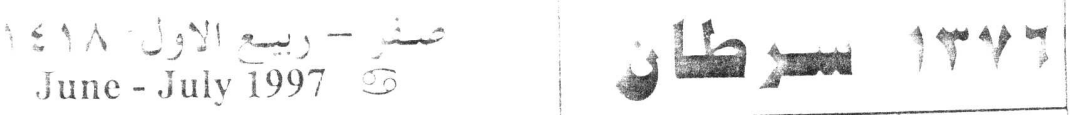

\begin{tabular}{|c|c|c|c|c|c|c|}
\hline & Funtrata & 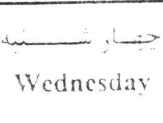 & Evater & Vonaulis & $\overline{z i m a x}$ & \\
\hline 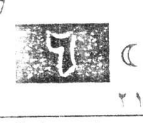 & 다요 & 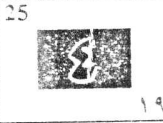 & 䤈 & 国 & 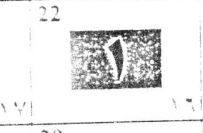 & \\
\hline |15il: & (1) & 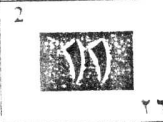 & 10 & 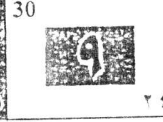 & 盛目 & Y \\
\hline 港倦 & 西虺 & Dis & , & 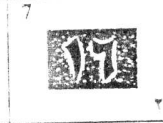 & .100 & 国造 \\
\hline \multirow[t]{2}{*}{ 通 } & 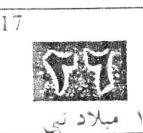 & "1 & (1) & "四通 & 道通 & "熥 \\
\hline & & & "湢 & "ris & [Fal & 四 \\
\hline
\end{tabular}

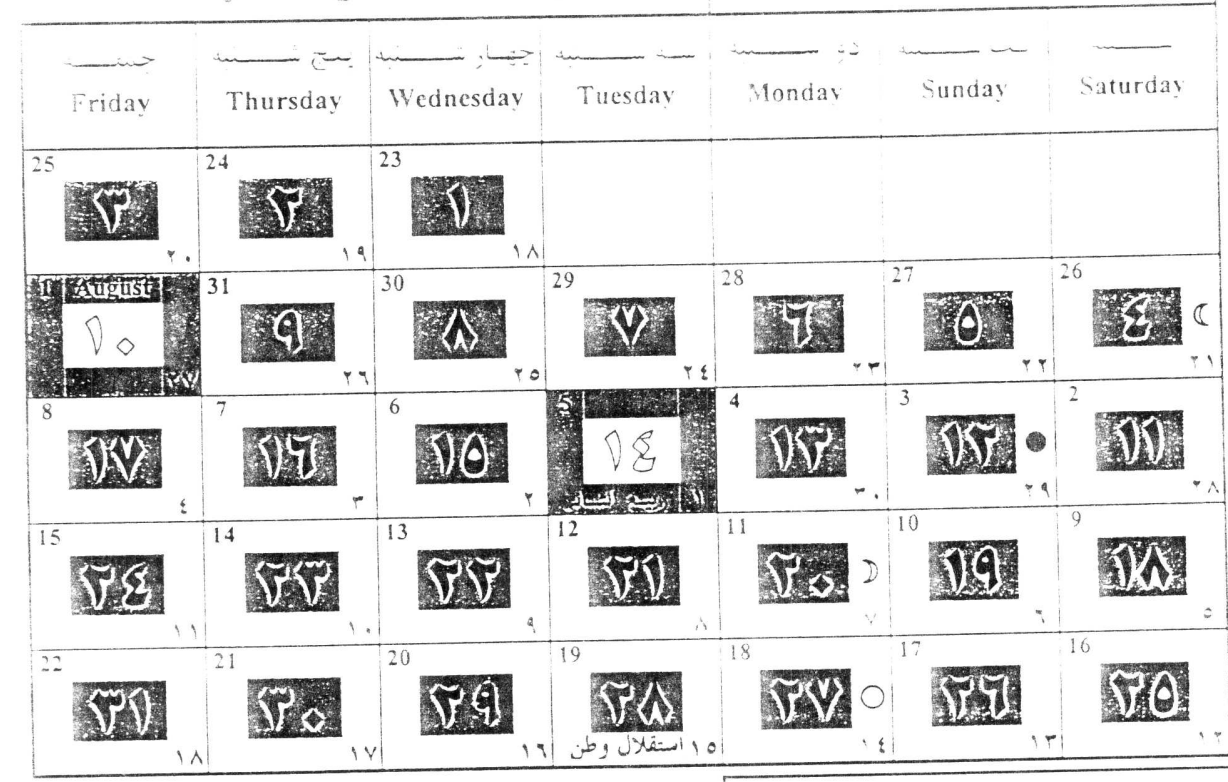

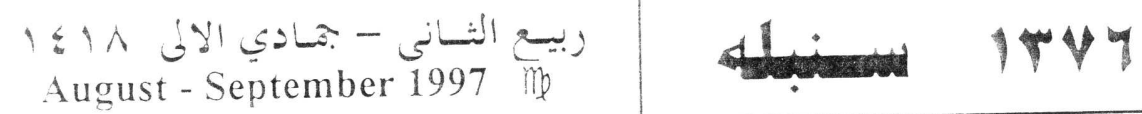

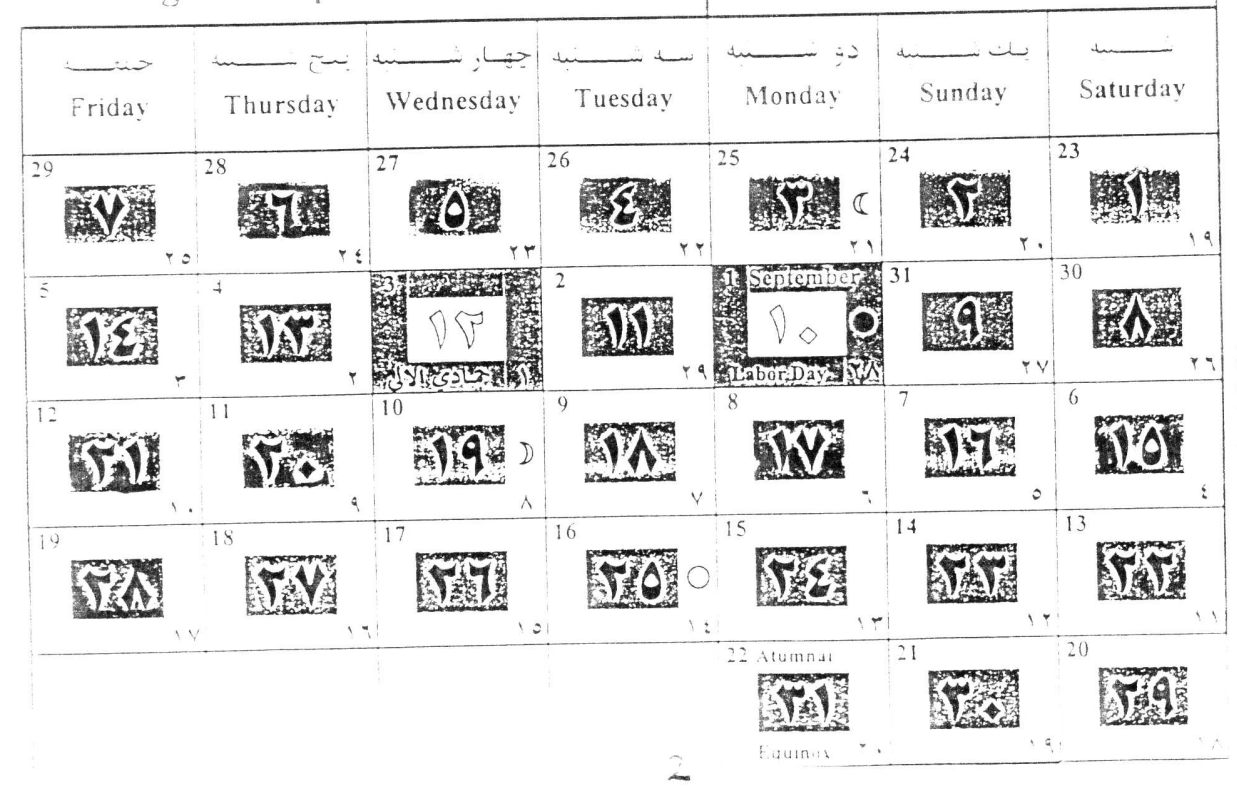

\section{DRERUIZATIDNS}

\section{AFGHAN YOUTH ASSOCIATION \\ The Afghan Youth Association is a non-}

rofit organization that was established on May 20.1994. The purpose of the Afchan Youth Association is to unite, organize, and guide ail of our Afghan youth to a better future, however the main goal of the AYA is the longterm development of the afghan youth and their heritage. A strong effort from AYA will be on the community. The AYA is not affiliated with any type of political or religious groups or organization. The AYA strives 10 teach nowledge in profound faith, Afghan culture. history, language and humanity. The guiding principle will be to help the Afghan Youth to succeed, and to become a better member of our society, by keeping away from drugs, gangs, and all illegal and criminal participation. Furthermore, to see the Afghan youth achieve much more honorable rank in the American society. The AYA will strive for improvement of responsibilities, beliefs, morals, and principles of young Afghans community as a wole. In order for AYA to accompish all the goals and efforts desired, we need the heip of our Afghan families. We as a community must realize that if we don't help our children,

no-one else will.

Mirwais Motawakel, President

10121 Jordan Avenue

Chatsworth, CA 91311

(from SABAWOON 2/20/97)

SABAWOON is a cultural, social a political journal in Pushto, with a few pages in English.

sabawoon

P.O. Box 8297

Eountain Valley, CA 92728 


\begin{abstract}
An zecognizing the Taliban as the
legitimate gov't in Afghanistan.

speaking to newsmen here. A.

mon Fischer of the Hliance Golgreens party in the Geminn PasLament sate that he was borred about the fate of the intelidencia ir. Aghancan "This is close lo a roiltous police state. In the rural prownces, the Taliban have prough: secumy. That is an advantage and the hives of the peopie thas not changed much. But we are amwons doout he fate of city cuiture ... adoul the onif real chy h Aghatrar te nave moved woynd deolory the rognt: It is the couny asung the city A nation whom an intelugensia is a dead place. ioses its political and culiural copacity." he added.

However, the German parianonwitian advised contnuing disogue with the Taibar. "I would line to contule to coperate with this oro:cmment until the sivation is sortert ati. But we would we the hajosto wory tah abou rovang their mencla for women. we woud also Whe them to do sometrung about it." ne side
\end{abstract}

- A - News (Rakistan) - A visitina

Jerman parliamentarian accused Taliban running "a religious police state," viding that the West should be cautious

-118 - NYT - Vawaz Sharif was sworn in as Prime Minister of Pakistan. ABP ceported several days ago that Taliban expected to "have better relations with the new Pakistani gov't.")

2/20 - Reuters - Taleban's acting deputy Foreign Minister said that if Pakistan supported any party against the Taleban, the Taleban would "be forced to strengthen their relations with India..." The new Pakistani Prime Minister said he was going to review his gov't's policy on Afghanistan.

- 25 - NYT - Taleban seized the Shibar Zass, the gateway to northern \& central Afghanistan, according to shariat Radio (formerly Kabul Radio).

$2 / 27$ - NYT - Two Erench aid workers were arrested in Kabul for fraternizing with Afghan women.
L/28 - Philadelphia Inquirer - Mart Nauman reported from thost that over 30 coed schools wre perating there \& that man. the teachers are female (see p. 41

$3 / 2$ - Reuters - A number of NGOS in Wabul have reduced their prourams until ther have a clearer idea of the position of their Eemale employees. Taleban says Afghan women can work in the medical sector but the Taleban militia is still preventind the women from going to work. - APP - "Photography \& Eilming of living objects is forbidaen in Afghanistan" according to the Taliban foreign ministry. However, Westerners living in Kabul can import zoreign publications for their own use, but the publications were banned from general aistribution. Acting Culture Minister Wulah Amir Khan Muttaqi said there were z daily newspapers \& two weeklies published in kabul \& that a monthly children's magazine had just been published.

3/5 - Associated Press - Taliban's religious police announced that gov't employees must wear turbans or face "severe punishment." - Reuters adas that the militia will punish men who trim their bearas. For trimmers, the punishment is 1 day in jail \& 2 lashes. Taleban says it is an Islamic obligation of all Moslem men to grow a beard long enough "to extend beyond a fist gripping the beard at the chin."

- AFP adds that foreign nationals as Afchans are banned - nom taking video ute machines out of Afghanistan.

3/6 - AFP - The Arab newspaper Al-Hayat saia that Saudi billionaire ossama bin Laden will bankroll development projects in southern Afghanistan; i.e., development of the

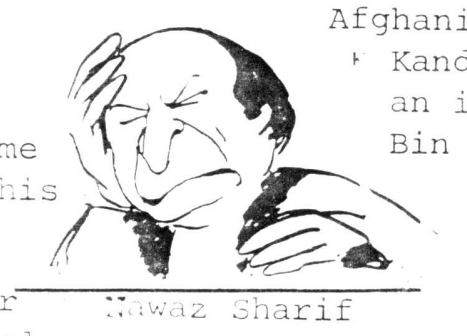
an irrigation system near Kandahar. Bin Laden, with his wife \& children are reportedly livina in Nanqarhar. The same report claims that Saudi Arabia is "the main provider of financial backing, through religious foundations, for the Taliban."

$3 / 9$ - Frontier Post (Peshawar) - Both Rabbani \& Hekmatyar have asked Nawaz Sharif for support against the Taliban. So zar there has been no response. 


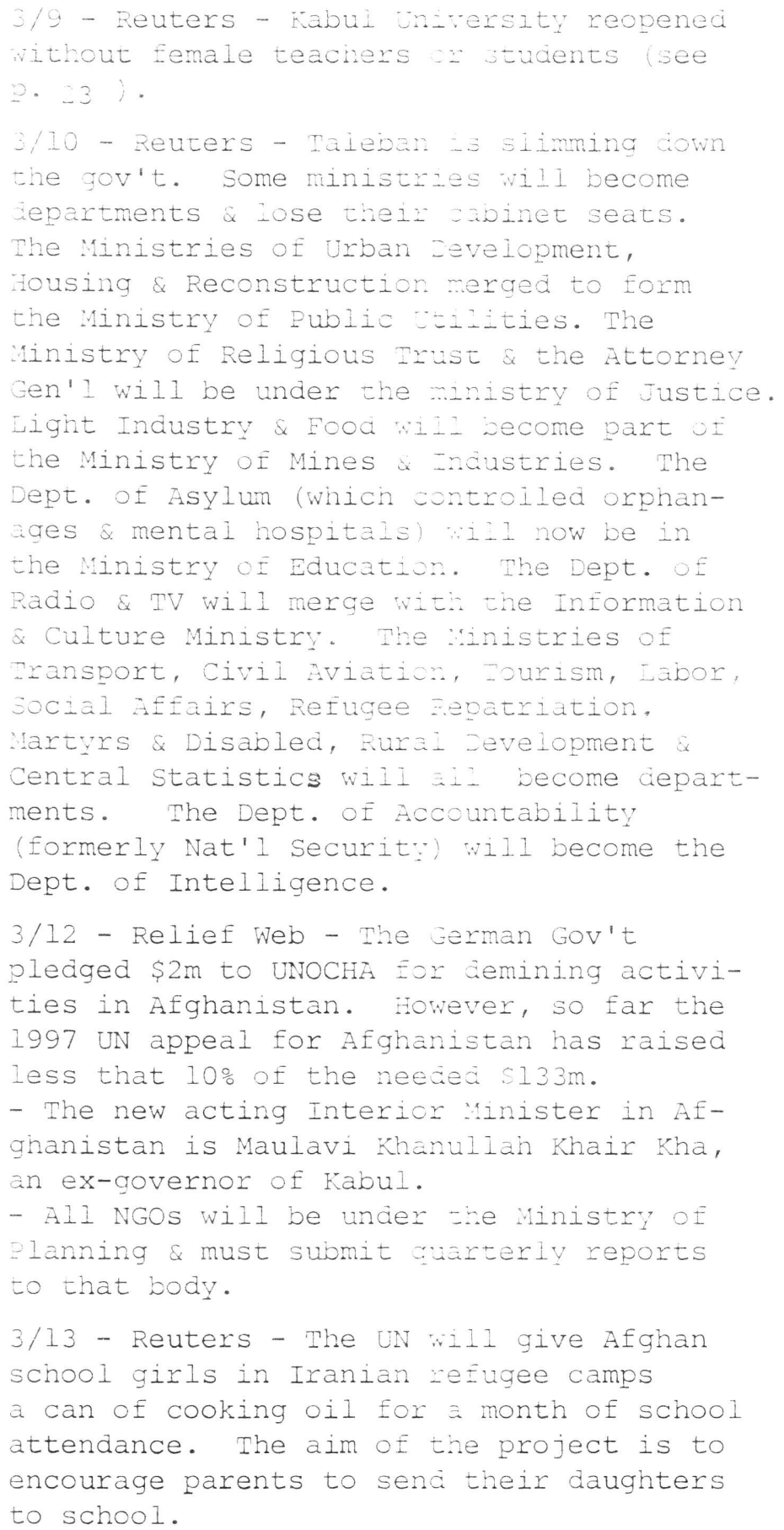

my plastic colis or pictures used as dornments on their tehicles. The orders came Erom the Dept. for Promoting Yirtue x Preventing Vice.

Taleban Jeader Wullah Moh'd omar ifered amnesty to all opposition fighters on the occasion of the Afghan New Year which, according to Taleban, will not be celebrated. (see p.2. ).

3/20 - WSJ - An ammunition dump exploded near Jalalabad killing at least $b$ \& wounding 300 . Reuters said the Dlast scattered debris over a radius of about a mile. The Dep. Gov. of Nangarhar said the explosion was an accident.

\section{3/22 - Afghan News Service - Thousands} of Afghans defied the Taliban ban on New Year celebrations \& gathered in Whair Thana to celebrate, perplexing some Ialiban solaiers who later, however, joined the festivities.

- Khalili's Hizb-e-wahdat will not let reinforcements from other anti-Taliban groups enter its territory, according to Asia Week. Speculation is that the group may be on the verge of collapse. - AFP - In quetta, over 2,000 Taliban supporters staged a rally demanding recognition by the OIC.

\section{$3 / 25$ - WP - In Pakistan, the State Department contributed funds to a volunteer group running a school for Afghan refugee girls, who otherwise would go without education.}

$3 / 28$ - NYT - An avalanche buried at least 100 people near the Salang Tunnel. Vehicular traffic has been halted by fighting but many travelers walk the 10 miles to catch a bus to go north.

\section{3/29 - Washington Times:}

Pakistani troops stormed an "Arab village" inside an Afghan refugee camp east of Peshawar in Pakistan's Northwest Frontier Province two days ago in search of the killers of an Algerian there. At least seven persons were killed in the operation. The walled village was occupied mainly by Egyptian, Syrian, Libyan and Lebanese who fought as Muslim "holy warriors" in Afghanistan's civil war. ... the Afghan Taleban militia, Mullah Umar, has asked Osama bin Laden to drop his opposition to the Saudi monarchy and adopt a friendly attitude, the Afghan Islamic Press news agency reports. 


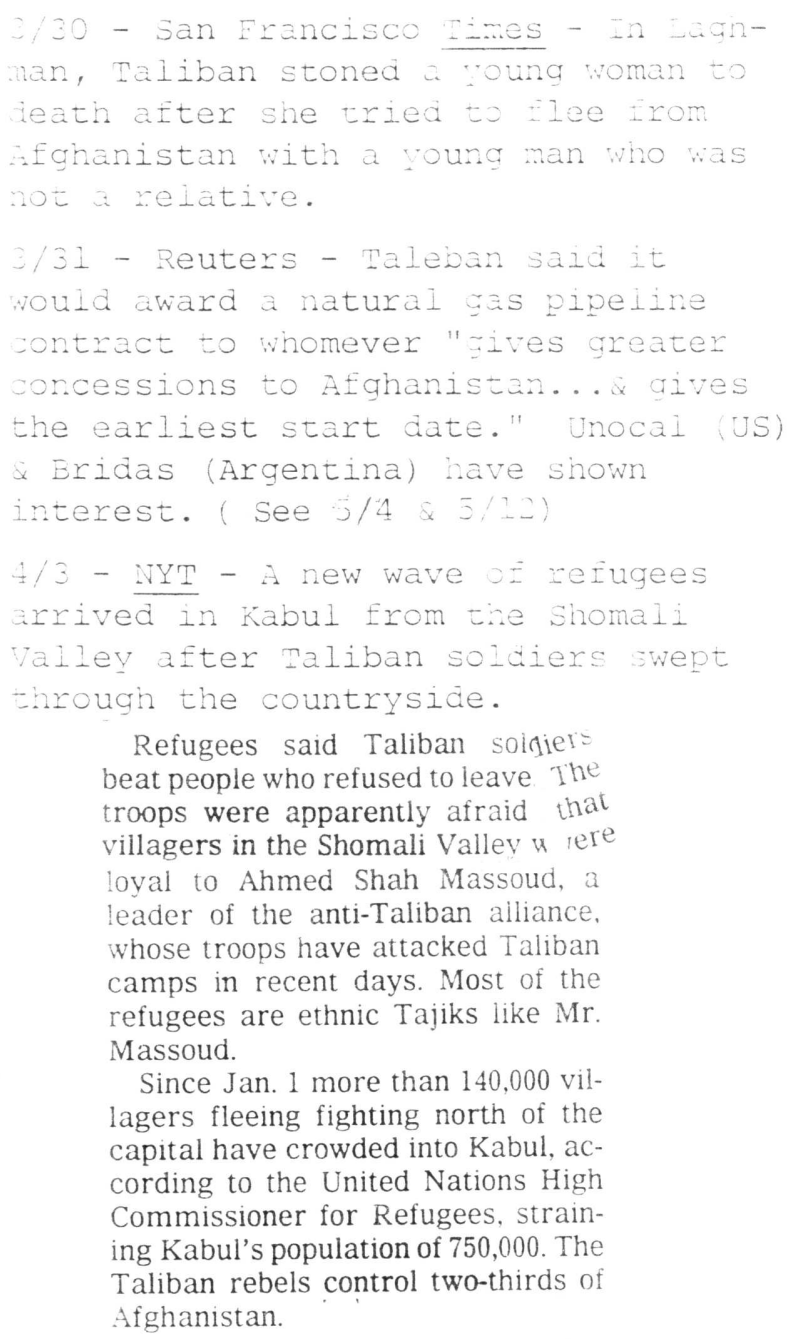

Since Jan. 1 more than 140,000 villagers fleeing fighting north of the capital have crowded into Kabul, according to the United Nations High Commissioner for Refugees, straining Kabul's population of 750,000 . The Taliban rebels control two-thirds of Afghanistan.

$4 / 4$ - Reuters - Pakistan closed its border on $3 / 27$ to check wheat smugging \& this has causea serious shortages in Afghanistan. The Horla Food Program is rushing zlour to Nabul where the price has risen to Afs. 10,400/kilo.

$4 / 6$ - Reuters - Taleban agreed to maintain a ceasefire while the UN tries to vaccinate $3.6 \mathrm{~m}$ Afghan children under 5 against polio. - Taliban officials say they have no desire to spread Taleban values beyond the borders of Afghanistan.

$4 / 7$ - The Afghan Islamic Press reported Ighting in Laghman between Taliban \& the forces of ousted Gov. Abdullah Jan. Taliban is also having problems with Jalaludain Haqqani who has been asked to witharaw his forces from kabul. Recert guerrilla attacks in Kunar, Laghman \& Nangarhar have been "neutralizea" accoraing to

\begin{abstract}
Zaliban, wut a spokesman admitted that oroblems in the area were not over.
\end{abstract} $\because \beta-\frac{\text { NYT }}{\text { weporting: }}$

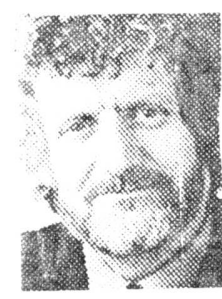
campfires with Afghan rebels and survived a stoning by rebel youths, using the same finely honed insticts for survival that helped him win his first Pulitzer Prize for international reporting in 1993 for his coverage of the strife and destruction in Bosnia. $\div / 10$ - Reuters - Taleban said Osama bin -aden has moved to Kandahar. He is wanted Wy US a Saudi authorities in connection ith terrorist bombings. Taleban said -e is a quest in Afghanistan a will be treated as such, but they will not let him carry out terrorist activities from Afghan soil. (See 3/6)

- Taleban's Mullah Moh'd Rabbani will meet with King Fahd of Saudi Arabia next week. - Taleban asked the UN to move its Afghan aid operations from Islamabad to Kabul saying it would save the UN money \& time. - Taleban claimed that Laghman \& Nangarhar are totally under its control; however, it denied making gains in Badghis a blamed the opposition for violating the vaccination ceasefire (see 4/6).

$\because 13$ - Reuters - Taleban asked for int' inancial help to promote sports since "sports is the only recreation for Afghans. The head of the Afghan Olympic Committee ilso called on all Afghan athletes abroad to come home to help their country compete. - Associated Press - Taliban jailed a shopkeeper who sold bread to a woman who was not a relative. His shop was closed a he was jailed for a week.

$4 / 15$ - AFP - Taliban claimed to have captured Car. Zahir (son of former Nanarhar Gov. Haji Abdul gadeer) in fighting southeast of Jalalabaa (see 5/12).

- Hizb-e-Wahdat claimed it captured Talisan edr. Abdul Wahid âter 3 days of ighting in the Ghorband Valley.

- At the UN, Pakistan asked the security council to listen to Taliban in order to get a more balanced picture of the sitution in Afghanistan. 


\begin{abstract}
- 15 - AEP - Two men were zalea zn
abul for shaving iff then beards.

$4 / 17$ - AFP - Taisban threatened

iemolish the oid Buadha statue

Bamian as it represents in "inziciel

-eligion.

- A1 6,000 Afghan nationais wno

made the hajj this year were reported

safe atter the huge Bire in Mina.

$\because / 21$ - AEP - Iranian-supplied mines

ceportediy are part of a growing rums

stock pile in nor.thwestern afghanis-

tan. The same report claims that che

number of Russian-made tanks a rocket-

launchers in the Bala Morahab distuict

f Badghis has doubled in the past

reek. A Dostam spokesman denied re-

ceiving any military aid Erom Iran.
\end{abstract}

YAI - AFP - Taliban saia it had re-

ceived a message of support from saudi

King Fahd; however, legal recognition

was not yet forthcoming.

- NYT - India's new Prime Minister, Kumar Gujral, who was Inaia's Amb. to Moscow when the USSR invaded Afghanistan, persuaded Mrs. Gandhi, then Prime Minister, to express opposition to the Soviet invasion \& to tell Brezhnev that he had blundered in Afghanistan.

4/23 - AFP - A military parade in

Mazar-i-sharif was held in anticipation

of the 5th anniversary of the overthrow

of the communist Afghan regime on $4 / 28 / 92$.

- Heavy Eighting in Badghis has sent at

least 25,000 people to safer areas.

- Dawn (Pakistan) reported that the US

state Dept. would continue to talk with

Taleban representatives even though the

Us does not recognize Taleban as the

legal gov't of Afghanistan.

$4 / 24$ - United Press Int'I - The UN asked

Taleban not to destroy the Bamiyan

Buadha (see 4/17) as it has "purely

historical \& cultural significance."

$4 / 26$ - AFP - Masood's Eorces claim to have surrounded Asadabad, the capital of Kunar, but the actual attack has been postponed because of bad weather.

$5 / 4$ - AFP - Argentina's Bridas Int'l will begin construction of a multi-biliion $\$$ gas pipeline crossing war-torn Afghani- ztan in 1998. The company hopes to sign the

Anal agreement within 30 days. The pipe-

ine wil run whough western \& southern

lEghanistan in areas controlled by Taliban.

The pipeine snould be completed in it vears,

rovide over 3,000 jobs will be the ist

major investment in Afghanistan for vears.

company oficial saia that Eridas was

'here to to business... roblems of hum

ciants \& women's rights are not our problems..

A consortium, incluaing a Saudi Arabian, a

us a European companies would put up the

capita1. (See 5/12)

$5 / 8$ - APP - J. Special envoy Norbert 4011.

Is back in Afghanistan searching for zresh

initiatives to halt the Eighting. In spite

f a lack progress he said that "there is

no sense of Eustration" in his mission.

:19 - Prontier Post - The Pakistani Foreign

Jilce denied any allegations that Pakistan

vas trying to create a 3rd force to rule in

Afghanistan in the event of a Taliban failure.

Masood had charged that the ISI was trying

to reactivate a union between Hekmatyar \&

Gen'I Tanai. And a representative of

Dostam accused Pakistan of interfering in

Afghanistan's internal affairs in order to

keep it weak, as a united \& powerful Afghanistan would threaten Pakistan. He said Af-

ghanistan was superior to Pakistan as Daki-

stan is only 50 years old while Afghanistan

has a history of over 5,000 years.

\section{$5 / 11$ - NYT - The Bag Ban of the Taliban}

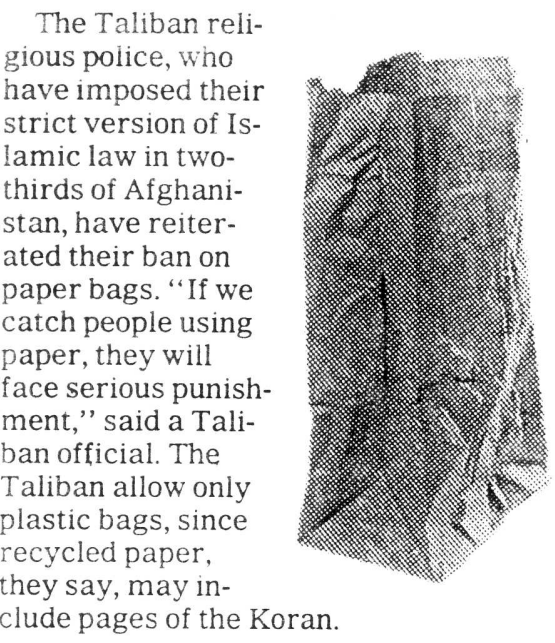

$5 / 12$ - NYT - The earthquake in eastern Iran also caused damage in western Afghanistan. Aia workers in Kabul said so far only 5 people had been reported killed but that reliei teams were still en route to assess the damage. 


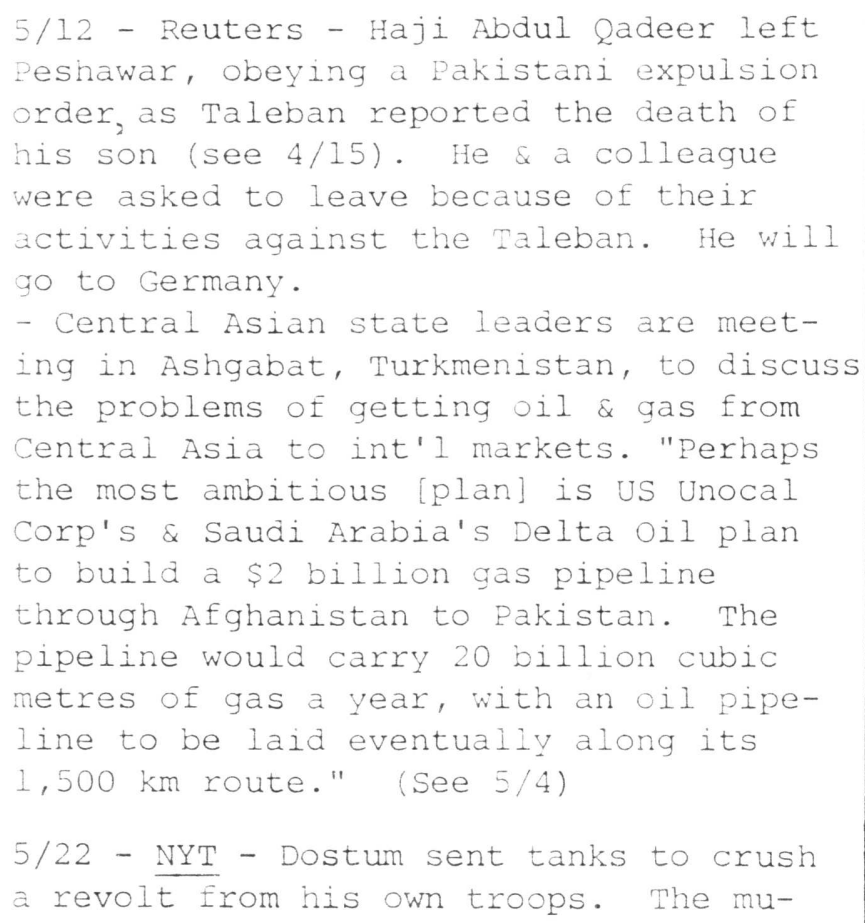

Ghafourzi is here to attend the seventh ministerial meeting of the Economic Cooperation Organization (ECO). He briefed Velayati on the latest developments in his country and called on Iran to continue its humanitarlan efforts and assisting the oppressed Afghan citizens.

Condemning foreign interventions in Afghanistan's internal affairs, Ghafourzi outlined blatant violations of human rights by the Taliban, IRNA reported. " "

Iran is ready to continue its peace efforts as before with an aim of settling Afghan crisis in an honorable and fair manner.

\section{BV RON KAMPEAS}

Associated Press Writer intervened." she said

December 1979) back.

\section{War Means Further Breeding of Haitred Among Muslims}

TEHRAN - The visiting Iranian Deputy Foreign Minister for AsiaPacific Affairs Alaeddin Boroujerdi met the head of the central council of Afghanistan's Harakat-i Islami, Hojjatoleslam Mohammad Ali Javid Friday in northern Afghanistan and figured the situation in strife-torn Afghanistan

Hojjatoleslam said A fghanistan was in need of peace and tranquillity more than at any other time.

He said, quoted by IRNA, the Afghan nation had lost many facilities over the preceding years and needed long years and huge
IRAN NEWS POLITICAL DESK

capital to emerge from its ruins.

He underlined the need for unity and solidarity between the Afghan people.

Boroujerdi for his part, underlined immediate end of hostilities in Afghanistan and said war meant further hatred among the Afghan people, because continuation of clashes resuits in more loss of life.

He underlined the need for holding of peace talks by all Afghan groups and wings.

\section{IRAN NEWS}

Quake rocks region: A strong
earthquake shook Afghanistan
and neighboring countries on
Tuesday, frightening Kabul resi-
dents during Islamic evening
prayers. Tri-vallev

Wednesday, February 5, 1997 4:09 am EST

washingtonpost.cem

KABUL. Afghanistan (AP) -- Shafika Habibi's nightly newscasts in firm. precise tones once soothed the frayed nerves of many Afghans in this war-shattered tapital.

But today, like so many other women in Afghanistan, Habibi has "disappeared."

Once held up as a symbol of women's emancipation in Afghanistan. Habibi's 35 -year career came to an abrupt end when the Taliban religious militia captured Kabul on Sept. 27. Imposing their strict version of Islam. Taliban leaders banned women from schools and most work places. saying the mixing of men and women leads to immorality

Habibi has left her apartment just once since then. to collect wages that the Taliban government continues to pay all women employees.

Women are just waiting," Habibi said. "It's boring."

Habibi's low profile made tracking her down a bit like ghost hunting.

She was not recognizable outside her home, dressed in the compulsory burqa -- a head-to-toe garment that allows only a mesh over the eyes.

"I used to wear the burqa out of choice, not to be recognized." she recalled wistfully.

She debuted in 1961, at age 16, as the country's first woman broadcaster. two years after emancipation for women. Her father, a doctor. was outraged. especially after she appeared on the front of a national magazine, head adorned with earphones, a symbol of the new Afghanistan

'He didn't want to see my face for six months ... and then. only after my brothers and mothers

When Afghan television was being set up in 1978. President Mohammed Daoud sought a woman newscaster to emphasize his commitment to equality. Habibi was a natural.

She feels her finest hour was the night Soviet invaders took over the broadcast building in

"The Russians moved into the station. They shot the guard in the forehead. They lined up all the workers and took us to a room." she said. "I was sure we were going to be shot."

Instead. they were kept hostage the whole night.

I begged them to let me broadcast. to reassure and calm people saying. The situation is calm

In the mornng. the Soviets agreed. Then. ther sent her home Six davs later. ther summoned he: 


\section{Tailk Rebels Said to Kill}

U.Y. Aide in Hosiage

Deal Gone Awry

By MICHAEL R. GORDON

IOSCOW. Feb. 13 - Tajik rebeis nave killed a United Nations observor thev had been holding hostage in a ampargn to secure the release of dlow insurgents, Russian news orranizations reported today.

the gunmen. who are under the ommand of Bakhrom Sodirov, have een holding 14 hostages, including nired Vations military observers. nited Nations refugee officials and everal Russian iournalists.

nited Nations officials sald they ad not been able to confirm the port and suggested that it might be

ruse. But Russian Government onil'als' response was to hint at miliary action against the rebels.

Prime Minister Viktor S. Chernomyrdin said tonight that the Russian military had been alerted to prepare for " all necessary measures."

The reported death underscores the growing danger for international ad workers, who have increasingly been targets of rebels, terrorists and warlords seeking world attention.

Six workers for the International committee of the Red Cross were shot and killed in Chechnya in December. The crime, which stunned the international aid community, has

et to be solved.

Tailikistan, a mountainous former oviet Central Asian republic. has been caught in a downward spiral of violence and hostage-taking.

About 25,000 Russian soldiers are stationed there to help keep Islamic fundamentalists in neighboring Afghanistan at bay. The United Nations has sent 44 military observers to Taijkistan to monitor the frequently violated cease-fire between the Government and rebel fighters.

In recent months, the United $\mathrm{Na}$ tions observers have been harassed. abducted and traded by rebels for comrades stranded in Afghanistan.

In the latest episode, Taiik rebels demanded that 40 of their fellows be transported from Afghanistan to $\mathrm{Ta}$ jikistan and released.

Although the Tajik Government flew most of the fighters to Tajikistan, their final release was delaved by disputes over how to exchange them for the hostages, said Aman Tuleyev, a senior Russian official.

\section{Hopes for Peace Pact Gain in Tajikistan}

BISHKEK, Kyrgyzstan, May 14 (Reuters) - In a a big sten tovard cementing peace atter four ears of (avil war. Taikistan areed todav to legalize maior slamic parties and ther news rganizations

The accord, part of a plan for : comprehensive peace settement. vas signed by President Imomal! Rakhmonov and the mam opposition leader. Sayid Abdullo Nuri. after two davs of talks in Bishkek. the capital of Kyrgyzstan.

They also agreed on an amnesty and an exchange of prisoners. Today's accord removed a big bstacle to the peace effort begun with a cease-fire signed last Desmber by Mr. Rakhmonov's secular Government and its Islamic opponents. That ended four vears of fighting that killed tens of thouands in Tailistan, a former soiet repubile.

Military terms for the accord and a power-sharing agreement had already been settled. But tocalization of the opposition and its press, as well as the amnesty, had stalled the talks, which were mediated by the United Vations. Russia and Iran.

The accord provides for legaiization of Tajikistan's three mam parties and of the opposition press after most of the oppos:tion's armed units are disbanded. The two sides have yet to agree on how many opposition representatives will be brought into the covernment.

YYT $5 / 19$

\section{Tajik Rebels Free U.N. Workers, Ending 2-Week Hostage Crisis}

DUSHANBE, Tajikistan, Feb. 17, (Reuters) - Islamic rebels in Tajikistan freed five United Nations workers and a Tajik official today, ending a two-week hostage crisis in the volatile former Soviet republic.

Taiik official said that President Imomail Rakhmonov, who had negotiated the release of the United $\mathrm{Na}$ tions workers, greeted them at the village of Obigarm, some 50 miles to the east of the capital, Dushanbe.

The United Nations workers, two military observers and three workers with the United Nations refugee agency, were on their way to $\mathrm{Du}$ shanbe, the official said.

Mr. Rakhmonov, who traveled to Obigarm to meet the rebels, said the talks had been aimed at reaching a final and peaceful solution to the standoff, which had dimmed hopes for peace in Tajikistan after a fouryear civil war.

The rebels brought the Tajik Security Minister, Saidamir Zukhurov, to the talks and freed him. He had been captured during earlier negotiations.

The crisis began on Feb. 4 , when a rebel group led by Bakhran Sadirov seized the first of 15 hostages and demanded that the Government allow his brother and 40 other supporters to join him from neighboring Afghanistan.

After several days of fruitless negotiations, Russia, which views Taiikistan as a barrier against the spread of Islamic fundamentalism. stepped in and demanded that all necessary means be used to free the hostages.

The Tajik authorities allowed more than 30 armed fighters to reach Mr. Sadirov's base on Saturday on the understanding that he would then free all his captives. But six were not released.

Last week the rebels said one of the United Nations observers had been shot, but the report turned out to be false. NYT $2 / 18$

\section{Tajikistan Rebel Group Agrees on Power Sharing}

DUSHANBE, Taiikistan, Feb. 22 (Reuters) - The Government and Islamic rebels fighting a civil war in Tajikistan have agreed to share power, officials said today.

Imomali Rakhmonov, President of the former Soviet republic, and Sayid Abdullo Nuri, the opposition leader, signed the agreement in the Iranian city of Meshed on Friday.

Zafar Saidov, Mr. Rakhmonov's spokesman, said here in the capital that the accord gave 13 seats of the new 26-member National Commission for Reconciliation to each side. The spokesman also said that $\mathrm{Mr}$. Nuri would be chairman of the commission and would return to Dushanbe from exile in Afghanistan two weeks after peace talks that are to start in Moscow Wednesday.

But sorne diplomats saw flaws in the agreement. since other groups 


\section{A Central Asian Web of Lies}

2. NAW DEWOLF SMITH

or the past two weeks, a masty mate stage situation lras been playing out $\mathrm{m}$ he fomer Soviet republic of Tajikistan. ou ve been following the news, you now oly think a sroun of Islamic rptoels ton we United Nations emnloyees and Russ. m journalists prisoner. And that then re rase marks another ugly chanter in a civi ar against the government of Tajikistan nd the 25,000 Russian moons allegediv ationed there to fend off botn Tayli amo ffghan fundamentalists. Trouble is. ... most none of that is true.

One key point emerges from my own reearch and that of other experts on Centr. Asia, most notably the veteran specialists n the post-Soviet states at the Jamestown Foundation in Washington: The hostant takers are not rebels, but Tajik governrent agents who have spent the past yent unting and killing the government s onents on both sides of the Afghan boy er. Even more disturbing is how many rom Moscow to the U.N. to Wasingtonre complicit in concealing the truth. F... me, the hostages have been spared. . . ns of thousanos have areadv nertsher. ne web of lies around Tajkistan.

\section{Fhuggish Brothers}

At the center of the current obfuscation tre the thuggish brothers Rizvon and Bakhrom Sodirov. Bakhrom's criminal specialty is hostage taking. Rizvon once fought against the government and even served briefly as commander in chief of opposition forces. But he was expelled from the opposition in 1995 for executing some of his own commanders and tortur ing civilians. It has not been proved. but the opposition also accused Rizvon of being a "KGB spy" who aimed to destros their cause from within. Both Sodirovs lasi vear joined the government's crack Prest dential Guard. Rizvon later met with Taih tificials and their Russian advisers to te reive the family's new assignment: H as returned to Afohanistan with a smat but heavily armed detachment of speciall: mined fighters to wreak havoc amon. Tajik upposition groups based. there. Brother Bakhrom was given the same ask, in the Tajik region of Garm.

Despite Bahhrom's best efforts, Gam Fell to the opposition late last vear. The Tajik government-unnerved by the spectacle of its demoralized soldiers sumen cering in droves-sued for peace. Since December cease-fire, negotlators have inched toward a power-sharing agreement. But the opposition says it won't sign unless the government fires the Sodirov brothers. The government has ample incentive of its own to do this, since the Sodirovs are desperate to link up in Tajikistan again so they can function as a "third sorce" in any future government-oppositon setup. This month, when the Dushanbe authorities took the first step and refused to let Rizvon come back from Ifrhamistan, Bakhrom kidnapped 16 U.N. military observers, refugee officials and journalists.

Considering their role in creating the Sodirov monsters, Russian and Tajik officials showed a lot of gall portraying themselves as white knights ready to ride to the ascue the noor hostages. Yet the Dushanbe regime had good reason to beteve the worid would swallow the most n- rectible disinformation.

the tale sninnme began in 1991, when aikistan's first democritic elections prouced a coatition government of Islamic matmentalsts and secular hoerals. This rouping was shaky, but also civersemething extremely useful in a country

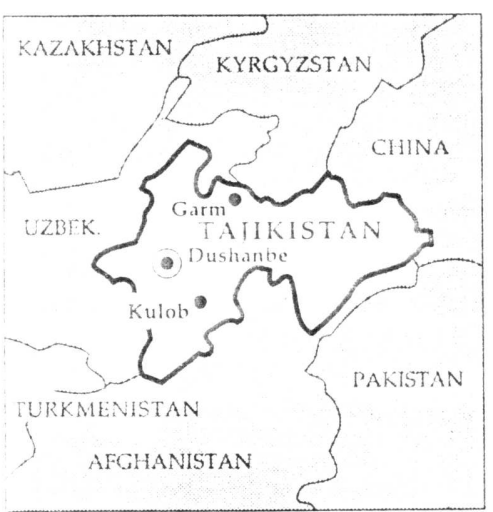

were the Tajik language (a dialect of isi) masks the wide variety of ethnic rotus. The presence of fundamentalists, nd a new government that owed nothing Moscow and was determined to break ith the past, drove the Russians wild.

What happened next is a textbook exumple of the Russian meddling that has opened rivers of blood across the former Soviet Union. Moscow's first task was to dentify fresh local puppet material. The bvious source was no longer viable. Durng Soviet times, Tajikistan was ruled with in iron fist from the northwestern region foninabad, the most developed and industrial vart of the country. By 1991 it was vear that the Leninabad clique was too iscreated at home and abroad to be oassed off as the Tajik neople's choice, so

Woscow went looking further afield.

it found a solution in the southern enlave of Kulob, where the Kulob clan was urning with resentment after decades of mpotence. Starting with a nucieus of forwer shecuve cotton-farm managers Hoscow established a paramilitary force, staffed with Russian officers. In a stroke of renius, the force was dubbed the Popular Front, its creators having guessed correctly that the West would be fooled by the name, or at least look the other way while the front battled Islamic meanies.

Moscow was richt. When the front finally overthrew Tajikistan's elected gov ernment in 1993, and Russia poured addi tional soldiers and materiel back into Tajikistan to support the new government, bardly a neep of protest came from the in ternational community. When Russia announced that it was sending 6,000 or so "neacekeeping" troops in addition to an es imated 15,00 to 20,000 borcier gruards, no one at the U.N. pointed out that the ruling Kulob clan had alienated virtualiy the entire country. The U.N. didn't even com plain when Russian planes bombed vilhages withn Tajikistan and refugee camps across the Afghan border.

The $U \mathrm{y}$ 's silence is one of the most sinister elements in this saga. Between hast summer and December, when Garm Ell to the mosition. U.N. cease-fire observers ana refugee worhers went through hell. The $\mathrm{C} . \mathrm{x}$. chief of mission, Gerd-Dietmen I.men. went out of his way to vilify the rebels. The U.N. was blatantly partin o the Tajik government in Dushanbe. 15 gining virtually every cease-fire volition , the opposition side.

What the U.N. tried to conceal was the at that its omployees were being ha-

assed and attacked repeatedly by un. comed soldiers of the Tajik army. White ir. Nerrem praised his hosts a Jushanbe, international workers were abjected to mock executions, robbed of ommunications equipment and denied acess to reported atrocity sites-all at the hands of government soldiers. The Tajik govermment probably hoped to scare the U.N. away and to conceal the extent of its ower loss to the opposition.

But why did the U.N. keep silent in the ace of these humiliating assaults? No one an know for sure. It's worth notung though, that the attacks came last summer and early fall, when U.N. chief Boutros Boutros-Ghali was still trying to hold onto this job and had Moscow on his side. By muffling criticism of Moscow's allies in Tajikistan, Mr. Boutros-Ghali may have hoped to solidify Russian support.

\section{1)ubious Distinction}

So much for the U.N. What's Wasing on's excuse? Tajikistan has the dubious fistinction of being the only former soviet epubiic where the U.S. made no attemmt o check Russian medding or even critiuze its military intervention. There may have been an explanation a few years back, when the Islamic angle had everyhe spooked. But now we know better. If Islamic fundamentalism is such a threat. why are Tajikistan's ex-Soviet neighbors-whose rulers are strongly commit ted to secularism-refusing to make any significant contribution to Tajikistan's defense? And why have the Uzbeks, the Kazakhs and the Kyrgyz spurned Moscow's offer to join a Commonwealth of Independent States defense grouping and onted instead to train their own Centra Asian force, under NATO's Partnership for Peace program?

After five vears spent trying to crush everything in their path, the Russians and their Taik wroteges anpear to have reat ized that there are worse things in life that accommodating opponents in a mains structure. Had anyone on the outside tried hard to point that out sooner, tens of thou sands of people would be alive today. Sitting the record straight now won't bring them back. Telling the truth from now of is the only way to help Tajikistan achieve a lasting peace.

Us. Smith is celtor of The Asim with

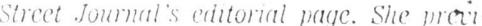
unsly covered Central Asia for Ratio Free Europe.

\section{THE WALL STREET JOURNAL} FEBRUARY 19, 1997

The Muslim World Monitor of $2 / 11$ reported that Massoud played a key role in mediating the weeklong crisis in Tajikistan. 
By David Rieff

TASHKENT, Uzbekistan $2^{\text {fter f }}$ ve years of fighting, the Afghan civil war finally seems on the verge of ending. Nothing is ever sure in Central Asia, where alliances are fluid and the balance of power precarious. But foreign diplomats, Government officials in Uzbekistan and aid agency workers seem persuaded that the victory of the Pakistani-backed fundamentalist Taliban militia may be only a few months away.

From a post-cold-war American perspective, this conflict and others in. Central Asia seem very far off. Yet a Taliban victory could further destabilize the Central Asian regions north of Afghanistan, in the territory of the former Soviet Union. That is a danger that American and European policy makers ignore at their own neril.

The Taliban has two principal opponents in Afghanistan: the largely ethnic Tajik forces of the military commander Ahmad Shah Massoud and the ethnic Uzbek army of Gen. Abdul Rashid Dostum.

The Massoud troops, driven out of Kabul by the Taliban, still control much of northeastern Afghanistan. General Dostum's troops are grouped around the city of Mazar-iSharif in the north-central part of the country.

These two groups cannot mount an effective resistance on their own, nor are they willing to pool their forces. And ordinary Afghan citizens are so sick of war that even a peace on the brutal terms offered by the Taliban has come to seem preferable to continued anarchy.

Meanwhile, the prospect of a Taliban victory has terrified Central Asian governments.

Such a victory would end the Tajik and Uzbek mini-states in northern Afghanistan, causing a refugee exodus of up to a half-million people, including tens of thousands of seasoned fighters. The arrival of these refugees in Uzbekistan and Tajikistan would exacerbate the conflicts already enveloping these two Central Asian republics.

Tajikistan, for example, has its own civil war, and the presence of Mr. Massoud would bring a new and far more militarily accomplished combatant to the conflict. In Uzbekistan, Islamic fundamentalism al- ready poses a grave threat to the Government, one that would be greatly bolstered by the presence of a Taliban state just across Uzbekistan's border.

Other Central Asian hostilities, too, are likely to be revived with a Taliban victory. The most dangerous of these are the Uzbekistan-Tajikistan tensions that date back to preSoviet times. Mr. Massoud has spoken of his dream of a "Greater Tajikistan," which would include a good part of what is now Uzbekistan. If he cannot rule in Afghanistan, Uzbek officials say privately, he may begin pursuing this goal. Uzbekistan invaded and briefly occupied Tajikistan in 1992; if it felt threatened, it could do so again.

If the Afghan war is effectively transposed north in this way, the effects would be stark and wideranging. Almost certainly, the smail steps this Central Asian region has taken toward stability would be undone, virtually guaranteeing a major Russian involvement in an area where Russia already has military forces.

A Taliban victory would also greatly facilitate the penetration of this group's particularly barbarous variant of militant Islamic fundamentalism into countries that, whatever their faults, have so far resisted its advance.

Yet American policy has been curiously ambivalent with regard to the Taliban, whose battlefield successes could never have taken place without considerable support from Pakistan, an American ally.

The United States seems to have done little to oppose Pakistan's sponsorship of the Taliban. Indeed, a common view in Central Asia is that the United States is backing the Taliban. Paradoxically, in the last several years, Iran has supported the more moderate Mr. Massoud.

The Afghan crisis has the possibility of destabilizing the entire region from Xinjiang in China's extreme northwest to the Black Sea. The need for engaged United States diplomacy is urgent. At this late date, however, the only effective action America can take will have to be in concert with other regional powers, including - whether Washington likes it or not - Iran.

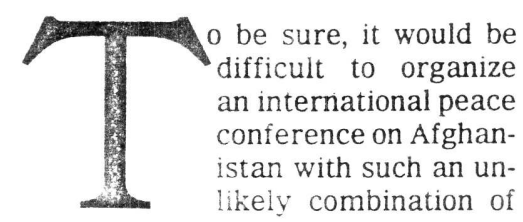

ontain/Lighan contlic

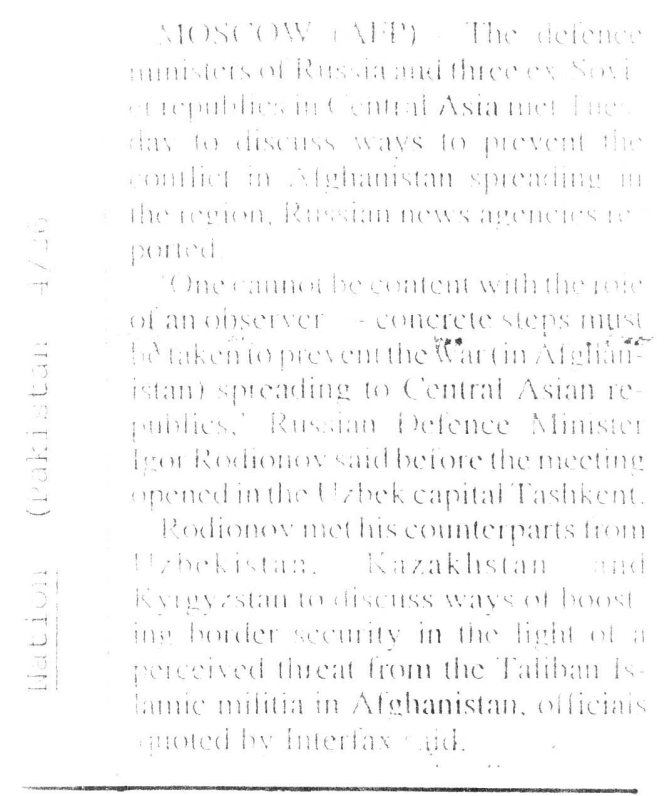

Taliban may destroy 2,000-year-old statues

GHORBAND VALLEY,
Afghanistan - Afghanistan's Taliban
rulers are threatening to destroy two
2,000 -year-old Buddhist statues they
regard as an insult to Islam.
The statues are in Bamyan
province in central Afghanistan, an
area controlled by Afghanistan's mi-
nority Shiite Muslims, led by Karim
Khalili.
But the Taliban, who like most
Afghans belong to the Sunni sect of
Islam, have amassed 3,500 soldiers
in neighboring Ghorband Valley in
a bid to take Bamyan.
Should they Succeed, the north-
ern one-third of the country, currently
controlled by an anti-Taliban alliance.
would be wide open to an attack.
-

participants - the United States, the front-line Central Asian states, Iran, India (which has actively backed $\mathrm{Mr}$. Massoud), Pakistan, Russia and the three main Afghan militias.

A successful outcome would be anything but assured. But standing by while the disaster unfolds is the height of irresponsibility.

David Rieff is the author of "Slaughterhouse: Bosnia and the Failure of the West."

THE NEW YORK TIMES OP-ED

MARCH 1, 1997 


\section{By JOHN F. BURNS}

KHINJAN, Afghanistan - The troubles of Pvt. Aleksei Ivanovich Olenin began on a snowy day in November 1982. On the morning of that dav, commanders summoned Soviet troops in Afghanistan to tell them that Leonid I. Brezhnev, the Soviet leader, had died at the age of 75 .

For many the news was not unwelcome, since Brezhnev had committed Soviet troops to their Afghan venture three winters earlier, with results that were already creating disaster. But for Private Olenin, the news from Moscow proved a false dawn on a day that was to change his life in more fundamental ways.

By dusk, he had driven his fuel tanker north from Kabul, the capital, over the Salang Pass through the Hindu Kush, and down the northern slopes of the mountains on the last leg of the run to a vast Soviet military camp. But the truck motor had been misfiring, and he had fallen behind the military convoy. Alone on a deserted road, he was ambushed.

His captors were members of one of the many Muslim guerrilla groups that had tied down the Soviet occupation force of 110,000 , drawing Moscow ever deeper into a morass that was hastening the demise of the Soviet Union, which finally occurred in 1991. The guerrillas fired rockets into Private Olenin's truck, then led him off, hands roped, into the mountains that were to be his home for the next 10 years.

After a few weeks, hungry and frightened, he made a deal. In return for better treatment, he followed other young Russians captured by the guerrilla groups and agreed to convert to the Muslim faith of his captors. For months he took instructions from a muilah, who was the son of the guerrilla group's commander Soon he was treated as a member of the group. He was assigned to work às a paramedic.

When the guerrillas arranged prisoner exchanges with Soviet commanders, or accepted Soviet bounties for releasing their prisoners, the former private chosi not to go back. After one of the other young Russians who had converted to Islam was exchanged, Mr. Olenin heard he had been taken to a Soviet camp, paraded before the troops, then run over by a tank. He decided he was safer with the guerrillas, and anyway, he felt comfortable as a Muslim.

"I saw something sacred in Islam that I had not found in Communism, or for that matter, in Orthodoxy," said Mr. Olenin, now 34, on a recent afternoon. He was referring to the Russian Orthodox faith of his forebears in Kuibyshev, the Volga River city, now renamed Samara, where was reared.

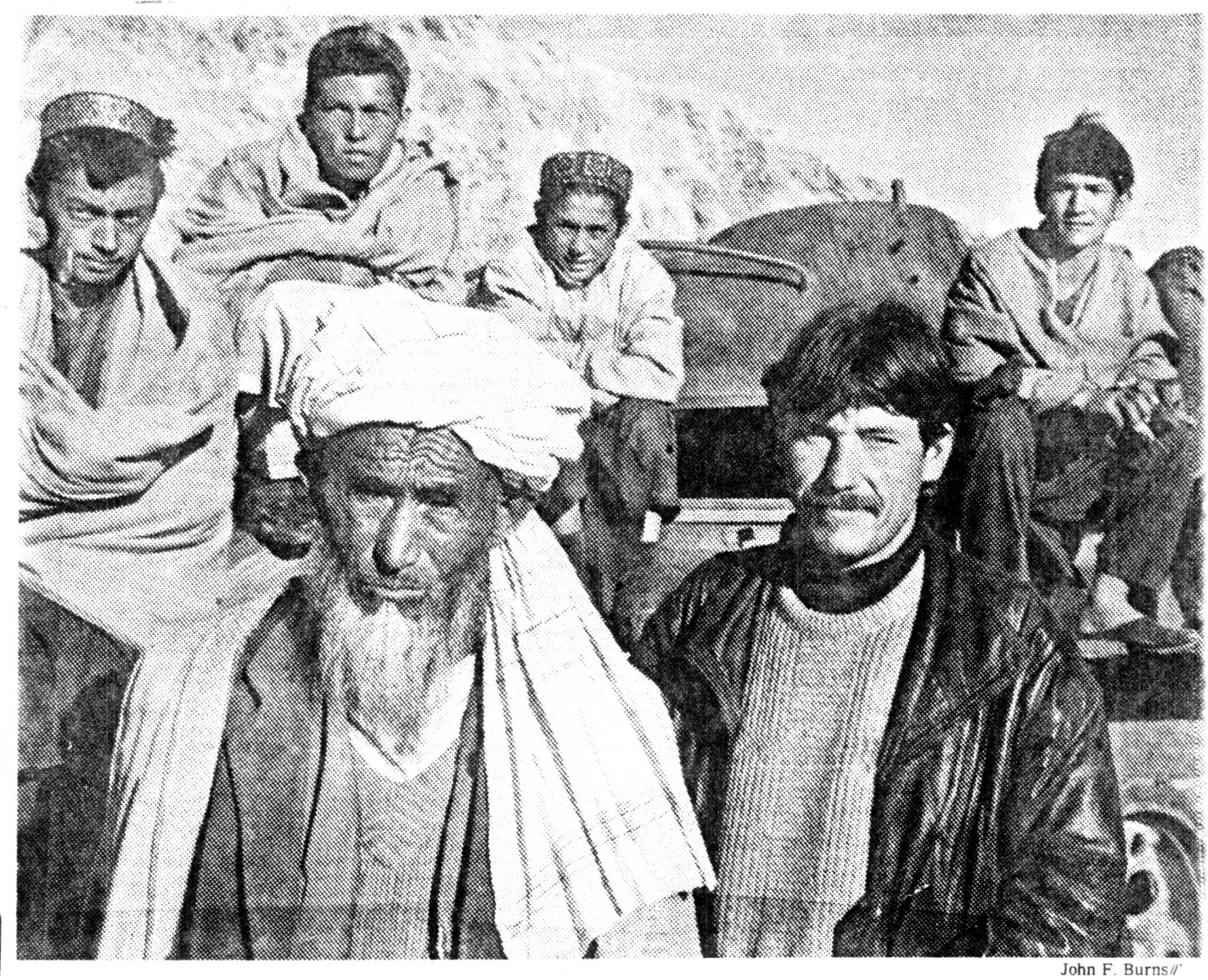

In the back seat of a car rolling northward from the Hindu Kush, Mr Olenin fell silent, then said: "Besides, the Soviet forces never took care of 'me. They treated me as if I was worthless, as though they didn't care if I lived or died.'

A few hours earlier, two Western reporters were relaxing in a mudwalled kebab house in the small town of Khinjan, a few miles from where Mr. Olenin had been captured 15 years earlier. They were talking with Afghans about the latest shift in the country's seemingly unending conflict, the rise of the militantly Islamic force known as the Taliban. Little noticed by any in the kebab house, a Slavic-looking man, Mr. Olenin, entered off the street, sat down in the dim light and listened.

After capturing Kabul in September, then stalling in their advance against the remnants of the anti-Soviet guerrilla groups, the Taliban have broken the impasse in recent weeks. They have swept northward to the Hindu Kush and are threatening to break through the mountains to the north. If they sweep through a narrow gateway west of Khinjan, as many northerners expect, the Taliban will be on the northern plains, and in a position to fight for the 11 Afghan provinces, out of 32 , that they do not already control.

Mr. Olenin said nothing as the Afhans voiced their thoughts.
First, they spoke dismissively of the Taliban, as fanatics who would suppress the freedoms enjoyed under the former guerrilla commanders who now rule. Then, as they relaxed, the men offered different opinions, saying the Taliban could not be worse than the northern warlords, who have taken arms and money from Iran, Russia and India to sustain their cause, while allowing large numbers of people to go hungry.

"Look around you here," said a former guerrilla fighter named $\mathrm{Na}$ dir Khan. "What do you see? All we know is destruction and darkness. Could the Taliban be worse?'

Mr. Olenin waited until the foreigners bade their farewells, then followed them out of the kebab house. Introducing himself by his Afghan name, Rahmatullah, loosely translated as God's grace, he asked if he could hitch a ride an hour nor thward to Pul-i-Khümri, where he had married an Afghan woman.

His only luggage, he said, would be what he held in his hands: a clothwrapped copy of the Koran, the Muslim holy book, and a plastic bag of oranges.

The journey placed Mr. Olenin on the road of his capture. Every few hundred yards were reminders of the fate of the Soviet occupation, in the form of wrecked tanks and armored carriers.

The car stopped once, for a photo- 
graph of Mr. Olenin beside a tank. Quickly, he was surrounded by Afghan children and villagers. "Shuravi!" they called, laughing, using the word Afghans use for Russians.

"No," he said, "Not Russian. Afghan."

When the Soviet Union coliapsed. Mr. Olenin went home. In 1993, with

an Afghan passport, he obtained a Russian visa and made an overland journey to Samara. Within weeks, an article appeared in a local newspaper describing him as a deserter.

Friends with contacts in the local police force told him, he said, that if he applied for Russian documents he would be arrested, despite an amnes. ty proclamation during Mikhail S. Gorbachev's tenure as leader.

Mr. Olenin headed back to Afghanistan, where he opened a small grocery store in Pul-i-Khumri. After it was robbed he took to the road, buying and seiling commodities like oranges in the towns that dot the northern plains, earning the equivalent of a dollar or two a day.

Now his marriage is failing, and he faces the possibility that the Taliban will sweep north, perhaps unfriendly toward any remnant of the Soviet occupation.

His solution, Mr. Olenin said, might be to head west to Iran, which although a Muslim state with a militant government might still give hir. a home. The Muslim-ruled country he has taken as his own has proved a place of violence and disorder, but he offers a rationale like the one that many Russians offered about Communism just before it collapsed.

"The fault in Afghanistan is not with Islam," he said. "The fauit is in the way that Islam has been corrupted here."

Asked if he thought matters wouid be better in Iran, he laughed mirthlessly. "I can hope so," he said.

And what of the choice he had made to turn his back on his homeland and embrace Afghanistan?

"Russia is my country," he said, "and my family is there. But God has put something in my heart, something that makes me want to go on searching, searching for honesty and justice and humanity. I haven't found it here, but God has given me an ocean of patience. Perhaps, in Iran, my luck will change.'

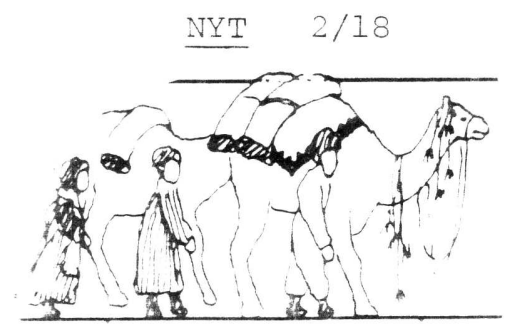

\section{As Foes Spinter. Afghan Islamic Victors}

BV JOHN F. BURNS

SALANG PASS, Afghanistan, Feb. - After being stalled for months on he plateau north of Kabul, the forces of. the militantiy Islamic Taliban movement are once more on the march across Afghanistan. Their objective this time is a breakthrough into northern flatlands beyond the peaks of the Hindu Kush mountains.

With the white flags that symbolize their brand of Islam fluttering from their tanks, the Taliban have broken the impasse that settled in after they captured Kabul, the capital, in September. Now they are close to a gateway through the mountains that would open the northern plains to their advance.

The challenges ahead are formidable, including a 12,500-foot mountain pass and a precipitous gorge that have been obstacles for armies crossing the Hindu Kush for at least 2.000 years. But the prize is great. too, since a breakthrough to the north would put the Taliban, who already control 21 of Afghanistan's 32 provinces, in a position to fight for the remaining 11 .

The situation has put new strains on the coalition known as the Northern Alliance, which was hurriedly formed in October, when the Taliban's last big offensive carried them on a rapid conquest of eastern Afghanistan, culminating in their seizure of Kabul. Three disparate fighting groups opposed to the Taliban met urgently in a small town on the northern slopes of the Hindu Kush.

But the pact they signed has been undermined by personal, political and tribal enmities. The three partners - Ahmad Shah Massoud, leading the Tajiks; Gen. Abdul Rashid Dostum, a former Communist who leads the Uzbek minority; and Abdul Karim Khalily, leader of the Hazara people - have not pooled their forces. This has plaved into the hands of the Taliban, whose units, mainly from the nation's largest ethnic group, the Pathans, have been increasingly effective in battle.

The commanders in northern Afghanistan, reeling from setbacks sustained in a Taliban offensive that began in mid-January, have been trying to steady their troops. Although the Taliban have paused while emissaries try to persuade front-line units of the northern armies to switch sides, many Afghans believe the Taliban could be fighting on the northern side of the mountains in a few weeks.

Some northern commanders have started evacuating their families and packing their household belongings. Others have said thev will fight. Mr.

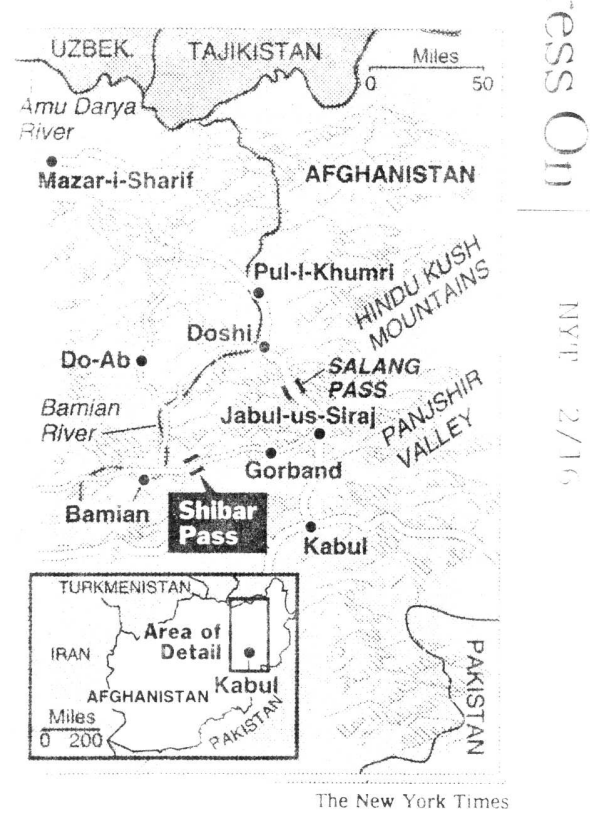

The 12,500-foot Shibar Pass stands in the Taliban's path.

Massoud told his commanders last week that they should prepare for the most difficult period in neariy 20 years of war.

"I told them, "If you stay with me, consider yourselves to be as good as dead," "Mr. Massoud told visitors to his stronghold in the Panjshir Valley. Mr. Massoud added: "The commanders talked it over with their camilies. Then they all came back.

A new test seems likely soon. since the weakest alliance partner. Mr. Khalily, controls the 12,500-foot Shibar Pass, which stands immediately in the Taliban's path. The route they are following, a 150-mile loop through the mountains, was forced on them when one of Mr. Massoud's commanders halted their advance in January by blasting a key bridge on the main north-south route.

From front-line positions barely five miles east of the pass, Taliban commanders have opened talks with Mr. Khalily, urging him not to fight. If he agrees, the Taliban could sweep forward rapidly. Beyond the pass, a local leader with nominal loyalties to Mr. Massoud, with forces controlling a gorge along the Bamian River, has told reporters that he will "run up the white flag.'

The 5 million Afghans who live in the northern provinces, out of a population of perhaps 16 million, enjoy freedoms that have been extinguished by the Taliban. In contrast to restrictions on women in Kabul and other cities under Taliban control, in the north women can work and dress as they please. Giris' schools remain open, and mosque attendance is voluntary. Alcohol, though officially 
roscribed, is freely available.

But alliance forces have

reakened by corruption and plung

ng morale. And there has been litt ign of support from Russia and the

Tusim countries on Afghanistan iorthern border, formerly part of the oviet Union, which met in Octobe nd branded the Taliban a threat heir own security.

What assistance there has as gone to General Dostum.

nander of the alliance's most power. ul military force. But even this avears to have been minimal.

"We have had no military support. ecause we don't need it," said Gen Yohammed Yusuf, an aide to Genral Dostum, who retains large num bers of Soviet-made tanks and artil ery pieces, as well as an asmg quadron of jet fighters and attach elicopters.

General Dostum has concentrated most of his firepower in the region round Mazar-i-Sharif, the northem uty that serves as his headquarte eaving more vulnerable areas to the suth to fend for themseives.

But military strategies are not the only problem. Popular feeling, too has shifted against the northern leaders. In Mazar-i-Sharif, and in towns and villages all the way to the Hindu Kush, people in bazaars and alleyways lower their voices when asked about the Taliban. Then, many say they would welcome the Islamic militants. "Under the white flag, we will have peace," they say.
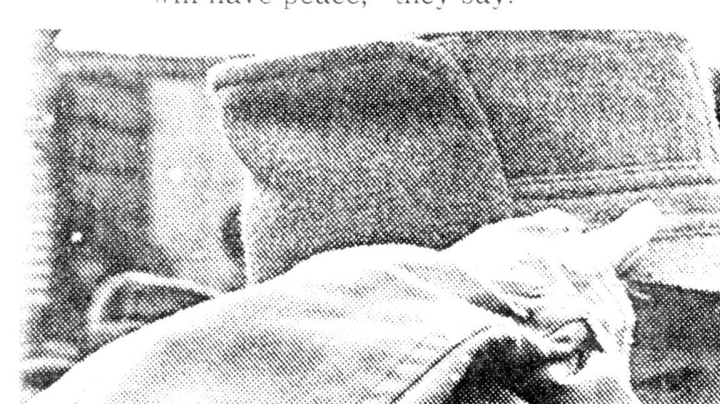

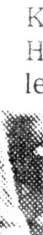

These people say the northern pops, especiaily Generai Dostum'

ave hoarded food staples and raided cal markets to take grain to sell in

he Muslim states to the north, short i food themselves as a result of poor arvests last vear. Bv dumning car. ads of Afghan currency into curbide exchange markets to buy up merican dollars. General Dostum? ommanders have aiso worsened an nlationary spiral that has caused hanv tamilies to go hungry.

The afghani, worth roughly the ame against the dollar in Kabul and Mazar-i-Sharif in October, has been evalued in northern markets by nore than 500 percent in four nonths. haif of that in the last three veeks. A unversity dean's monthly alarv. \$10 in October, is less than $\$ 2$ ow, nough to buy a few days' supiv of the flat, unleavened bread that the staple of the Afghan diet.

aced with large numbers of peole who want to flee, General Dosim has asked consulates of neighormg Muslim countries in Mazar-1harif not to issue visas to would-be efugees. A tightening of patrols has irtually sealed the border along the mu Darya River to northbound ravel by all except General Dostum's loyalists, who shuttle north to Uzbekistan and Tajikistan with famly members, household goods and briefcases stuffed with dollars.

The problems facing the northern coalition seem clearer still in Pul-iKhumri, a town on the slopes of the Hindu Kush. The area's defenses are led by Said Jaffer Nadiri, best known fghanistan as a plavbov wno ropped out of a Pennsylvania hict chool to become a teen-age general his lather's pro-Soviet militia orce. Now 32, Mr. Nadiri offered ncouragement last weekend to hunreds of men sitting cross-legged on he lloor of a locai mosque. "I will efend vou and vour homes to the ast drop of my blood." he sald.

th his heavily guarded compou $n$ the outskirts of town, a differen attitude was evident. With his wit and children saiely in Mazar-1-Sha if, Mr. Nadiri had unpiugged appiinces, ready for packing. In a build ng housing a swimming pool and ar, even the pinup calendars were one. Over a bottle of whiskv, Mr vadiri confessed to doubts.

"Nobody knows what's going happen," he said. "Anybody who ells you anything differint is lying.

Afghan Rulers' Troops

\section{duance in North}

\section{LAMABAD, Pakistan, May}

uters) - Afghanistan's rulin.

aliban movement said today that

forces were advancing to take

orthwestern province of Faryab

the northern Uzbek chief

bdul Rashid Dostum, lost cont

efore today's action, dissidt

rees led by Gen. Abdul Malik began

pro-Taliban revolt in four prov-

nces held by General Dostum: Far-

yab. Samangan, Jowzjan and Balkh.

the Afghan Islamic Press reported.

The press agency said General Malik had publicly announced support for the Taliban today. The general aiso said he had captured 3,000 of Generai Dostum's soldiers.

hting for control of Afghanistan's north is expected to begin soon. In Pul-i-Khumri, a northern town, Said Jaffer Nadiri saluted his troops 


\section{Afghanistan's Intoxication with Violence}

Mostafa Danesch
Aflowing the downtall of the Socialists,
telligence service which now plays an
mportant role in Kabul, the capitai.
Even after two decades of war, there
seems little prospect of a peacefui set-
tement. An entire generation of Af-
ghanis has learned nothing but armed
ombat.

In April 1992. when the mujahedin marched victorious in the Afghan capttai or Kabul, the head of the Khad secret service, Farooq Jakubi, commited suicide. Since then, though the fay rs have changed, the game has remaned the same. The mujanedin toos ver the structures of the Khad apparaus and founded a new secret service. the "National Security." In addition to prison camps in the Panjir Valley isee box), they maintain a secret-service prison in Kabul, where they torture pris oners under investigative arrest Situated in the middle of Kabul, it is known as the Rijasate Tahgig (Office of Investigation). Since former rebel leader Shan Massoud and his president Rabbant restored order to Kabul something over a year ago, driving all other mulahedin factions from the city, the National Security service has grown prodiglousty. Rumor has it that 5,000 agents and soes are now active on the streets of the Afghan capital.

A yourn man named Gholam languished in "investigative arrest" for 60 days, crammed with 30 other prisoners into a tiny underground cell, without water or sanitary facilities, before he was transferred to a labor camp in the Panjir. He was blindfolded for weeks, he says, beater, hicked and tortured with thumb-screws. His right ear has gone deaf from the beatings he endured.

"Massoud is essentially the government, says Navid Fereydon, a prominent Afghan journalist, "his secret service rules and the army is totally infiltrated with his people." In Fereydon's view, neither President Rabbani nor Prime Minister Hekmatyar, a once-feared fundamentalist leader, now has much influence.

When the Communists were in power are Frevdon was ior severai yeu head of the cultural program of Kabul Th. Later, under the watchful eyes of he victorious mujahedin, he anchored the $\mathrm{T}$ news broadcast. But arter $10 u r$ vears he gave up. In 1994 more than 400 intellectuals were abducted and mur tered - - achers, protecenrs actors $\mathrm{Hm}$ makers - acrused by Massoua of colahorating with the enemv. Univ three Herevdon's 90 torme: IV colleagus - main. The 30 women who once served is announcers on Afghan TV have disuppeared. Not long ago, when the mujahedin were looking for a female spokesperson on TV, they could find no women willing to take the job.

Fereydon notes bitterly that, at age

he is a member of a lost generation. The spirit has been extinguished from his country. Whoever is not dead, abducted or in exile, he says, has been bearing arms for almost 20 years and is no longer good for anything but wat For militiamen, war has become the natural state of things. For the militar: commanders, peace would mean the loss of their power and wealth; for the ordinary soldiers, who have learned nothing but combat, it would mean starvation. And so, the journalist contudes, the spiral of violence will con inue indefinitely.

Vuruilah, a heavyset and crude an anment troop commander, is an exam. ple of the generation that has lived its lite in the trenches. He proudly tells of his fourth wife, who is 10 years old. He has a preference tor "young women," he says, and launches into the story of one of his former wives, a 9-year-old: During the jibad, the holy war against the Soviet occupation of Afghanistan, Nurullah came to a village one day with his militia, and saw a pretty little girl playing in front of a house. He wanted the girl and approached her parents, who gave their consent. The village mullah was quickly called, he read the appropriate passages of the Koran, and Nurullah and the girl were married. A few days later, Nurullah ends his impassively recounted tale, the girl was dead. Who could blame him for anything? The marriage was legal according to the Sharia.

The Kabul regime also legitimizes its

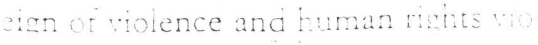

ations by calling on the Shari a. Atghan ourts have degenerated into a system of Islamic kangaroo courts doling out nhuman punishment. This is how the zovernment retains its control over the poor, sulfering souls who still live in Cabul. The graveyard peace that premed linere at the time of this wrting oukl not mask the tact that whe lires of war continued to smolder beneatin the ndless ruins.

For centuries, Kabul was the residence of Afghan kings, integrating tigures who functioned as mediators between the country's various tribes and the local khans, or warlords. With the coppling of King Zahir in 1973 the seed was sown for a line of development that was to lead to a dead end. The prociamation of the republic, the election of a president and a parliament as the high est legislative authority - these things added up to an unmistakable deciaration of war against the tribal chiertains. When the Socialists under President Taraki took power in April 1978, and Soviet troops invaded in December 1979, the conflict intensified. With its reforms of the school system and agriculture, and its proclamation of women's liberation, the radical Socialist program called all Afghan traditions into question. The Soviet Union's intervention mobilized another traditional element of Afghan resistance: the will to independence. So instead of retorms. Afghanistan experienced a grisiy war.

When mutually hostile mulahedin groups took power in April 1992, any traditional or modern structures that vere still functioning collapsed. Instead of the oid khans, today's local rulers are hundreds of military commanders and drug barons; instead of sabers and rusty old rifles, they now impose their medieval ideas with Stinger missiles and Kalashnikov automatic weapons. There is no dialogue, only the language of bombs.

Afghanistan's petty rulers do not even consider subordinating themselves to the central government. Journalist Fereydon therefore believes that war will continue for years to come. The chief political actors are not honest, he says; every coalition they form is based on ulterior motives. They always carry a dagger hidden in their robes.

\footnotetext{
Swiss Review of World Affairs Octover 1996
} 


\section{A Visit From the Men (Oniy) Who Now Rule Afghanistal}

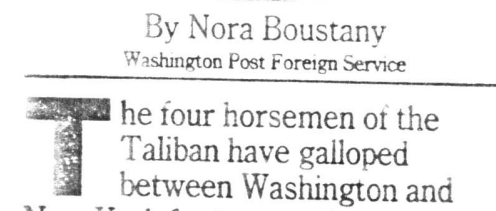

New York for two weeks, meeting officials and giving interviews in a bid for recognition of Afghanistan's Taliban government. They came with green diplomatic passports issued by the new Islamic fundamentalist rulers in Kabul, the Afghan capital, and U.S. visas granted in Pakistan.

They sat as far away as possible from the bar at Alexandria's Afghan Restaurant during a meeting last Wednesday. But the Taliban quartet seemed merry enough with their kebabs and mountains of rice.

Under a 30 -foot mural of a sand-blown scene of horse carts and women in full-length veils in faraway Afghanistan sat Mawlawi Wakil Ahmed, senior adviser to Mullah Omar, the one-eyed supreme leader of the Taliban Islamic movement; Abdel Hakim Mujahed, ambassador-designate to the United Nations; Mawlawi Abdel Wahab, a former Afghan diplomat in Islamabad, and Refugee Minister Mawlawi Abdel Raqib, a wiry Uzbek from northern Afghanistan.

Wakil Ahmed said the visit had four aims: to talk to Afghan Americans, to seek transfer of the Afghan seat at the United Nations from the old government to the Taliban rulers, to continue a dialogue begun with U.S. envoys in Pakistan, and lastly, "There is a lot of propaganda. ... We wanted to explain ourselves, who we are."

The four wore traditional tunics and pantaloons. Two also wore pakuls, puffy tweed-brim hats, while the two clerics went for the mystical look of twisted white turbans with tails.

The Taliban-imposed segregation of the sexes has led to the shutdown of schools and public bathhouses and denied medical care to female patients, drawing an international outcry. One goal of the trip, Wakil Ahmed explained, is to recruit Afghan women with medical skills for service in Afghanistan.

In response to concern over hygiene after the bathhouse closures, Wakil Ahmed stressed that "some bathhouses were shut to women only.

Why?

"Nothing personal," interjected Mujahed, behind thick glasses.

"The measure was administrative. Intelligence services of the ousted government used taxicabs and bathhouses to exchange secret messages," he said, his eyes widening.

"In some bathhouses, the problem was bigger, people were killed," continued Abdel Raqib.

The victims? "A woman," added Wakil Ahmed. Who dunnit? "The: one who killed the woman was a man." the mullah asserted.
Confused? Never mind, it was also the only case. In pre-Taliban days, the bathhouses were used by men and women, using one entrance leading to separate chambers. "This does not mean that only women used the bathhouses for espionage," he elaborated. Even to Sam Spade, this shall remain a slippery mystery.

But state-building is on their mind. The group said it is hoping for a pariiament that will monitor conduct according to sharia, or Islamic law. "Laws inconsistent with the sharia will be changed," said Wakil Anmed, returning to more familiar ground.

Economics? Expenditures are low, since no salaries are paid. Revenue? No problem, since the Taliban seized customs and border posts. Drug policy? Hashish and alcohol are illegal and their production, sale and consumption are forbidden. And opium? "We have been active in banning its transfer into heroin, but we have not done anything against its cultivation," Wakil Ahmed said. "If we ban opium, people will say, 'How can we buy food?' We have to provide alternatives," he argued.

Februarr 26.1997

\section{NOTES FROM HEIRE AND THEIRE}

\section{A Close Encounter With Taliban}

Feeling maligned and misunderstood, the Taliban came to the East Bay over the weekend. On their bad list are the New York Times (graphic stories about Islam. ic punishments) and the Russians, who they fear will lobby against them at the ClintonYeltsin summit. Taliban objectives on their U.S. visit are the Afghanistan seat at the United Nations and U.S. recognition of their government. Surprisingly, they like what they've seen of this country; they consider us advanced, even though we have such a short history.

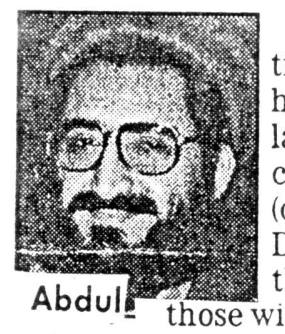

that for a time, it wasn't safe for females to be out of the house.

Mowlawi Wakil Ahmad, a member of the High Shora (ruling council), said that America has been a friend to the Afghan people and that the Taliban have come to explain themselves. Asked what they need beyond status as a legitimate government, he said aid in eliminating drug cultivation and trafficking. (Keep saying that; Washington likes to hear it.)

Hakeem wisdom. You know them when
Mujahid you see them. (This is not a concept
that is easily translated.)

Abdul Hakeem Mujahid, one of four Taliban leaders meeting Bay Area Afghans, said he is optimistic about gaining recognition but must overcome "bad propaganda and disinformation" about human rights, and women's rights. Mujanid, who will be the Taliban's U.N. ambassador if there is one, says women have worked and will work (as nurses, doctors, teachers, police officers); girls have been and will be educated. (The Koran demands that, and to the same levclas men.) The Taliban's position is
The democracy question is stickier. They shall have it. he said. but an Islamic version. No political parties, no one man (or one person), one vote. Decisions will be made through consensus by The Taliban leaders speak with they are out of step with a world whose help they desperately need to reconstruct a nation from rubble. They may pose no threat to their northern neighbors, but they have not made that clear. These are not masters of PR. They lost points when former Afghan President Najibullah (no saint, he) and his brother, the onetime security chief, were lynched in Kabul and unpleasant things done to their bodies before they expired. care. They are not wild-eyed. But
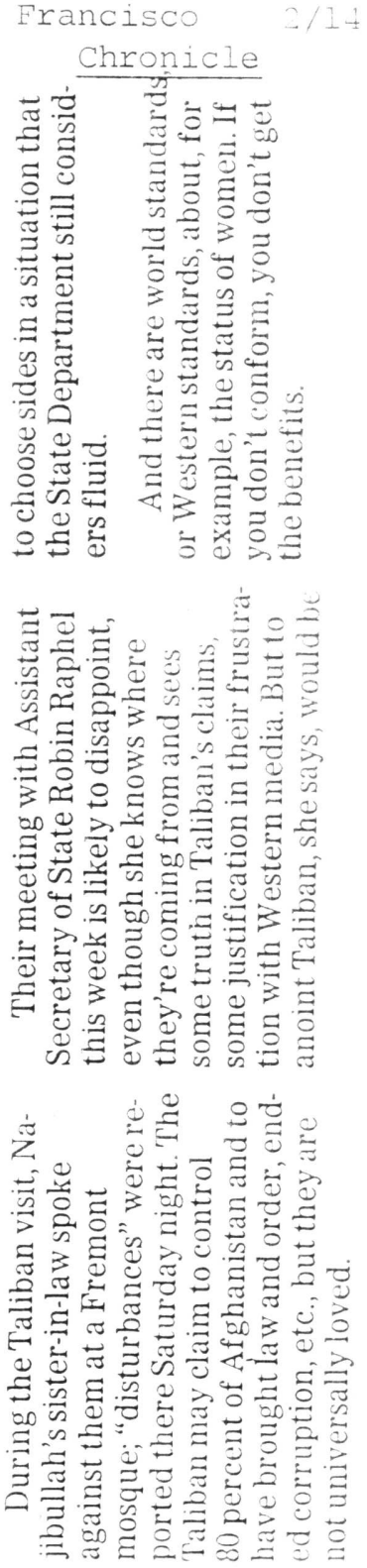


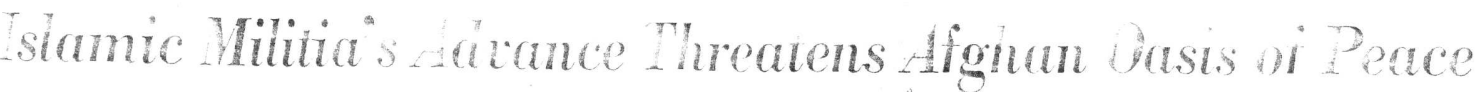

\begin{tabular}{l} 
By Kenneth J. Cooper \\
Washungton Post Foreign Service \\
\hline
\end{tabular}

MAZAR-E-SHARIF, Afghanistan 韋 eariy two decades of war in 3. Afghanistan have hardy touched this city on the dusty northern plains, making it a popular refuge for families fleeing Kabul, the capital, and other war-torn areas. Thousands of refugees from fighting in neighboring Tajikistan also have come here to find safety.

But the northward advance of the Taliban Islamic militia now threatens this refuge. In a surprise winter offensive, the Taliban last month recaptured erritory north of Kabui from the guerrilla forces that constitute the government that the Taliban cnased out of $\mathrm{Ka}$ sui last September. The Islamic force oushed into the snow-capped Hindu Kush mountains, which heiped protect the north during a decade of war against the Soviet army and another eight years of factional fighting.

There is much to be coveted in the north, including oil and natural gas fields, as well as industry developed during the Soviet occupation. Abdurrashid Dostum, an ethnic Uzbek who is one of the leaders of the anti-Taliban alliance, has relied partly on those economic assets in six northern provinces to sustain a virtual ministate that boasts its own army, flag, airline and currency.

But more is at stake than control of the north's resources. The threatened expansion of the civil war has heightened fears in Russia and several other former Soviet states that the Taliban will attempt to export its brand of Isamic fundamentalism-perhaps the strictest in the worid-to neighboring Muslim states. In areas under their control, Taliban leaders have banned women from work and school and prohibited diversions ranging from television to kite-flying.

The threat also has intensified competition between Iran and Pakistan for dominance of routes through Afghanistan for potentially lucrative trade with Central Ásia.

Russian officiais have renewed warnings they first made after the Taliban captured Kabul that unspecified countermeasures will be taken if the militia seeks to expand into former Soviet territory. The top fussian diplomat here in Mazar-e-Sharif has said if the Taliban seizes the city of 200,000, which lies about 40 miles from Afghanistan's torder with Uabekistan. the conques mould be regarded as a security threat

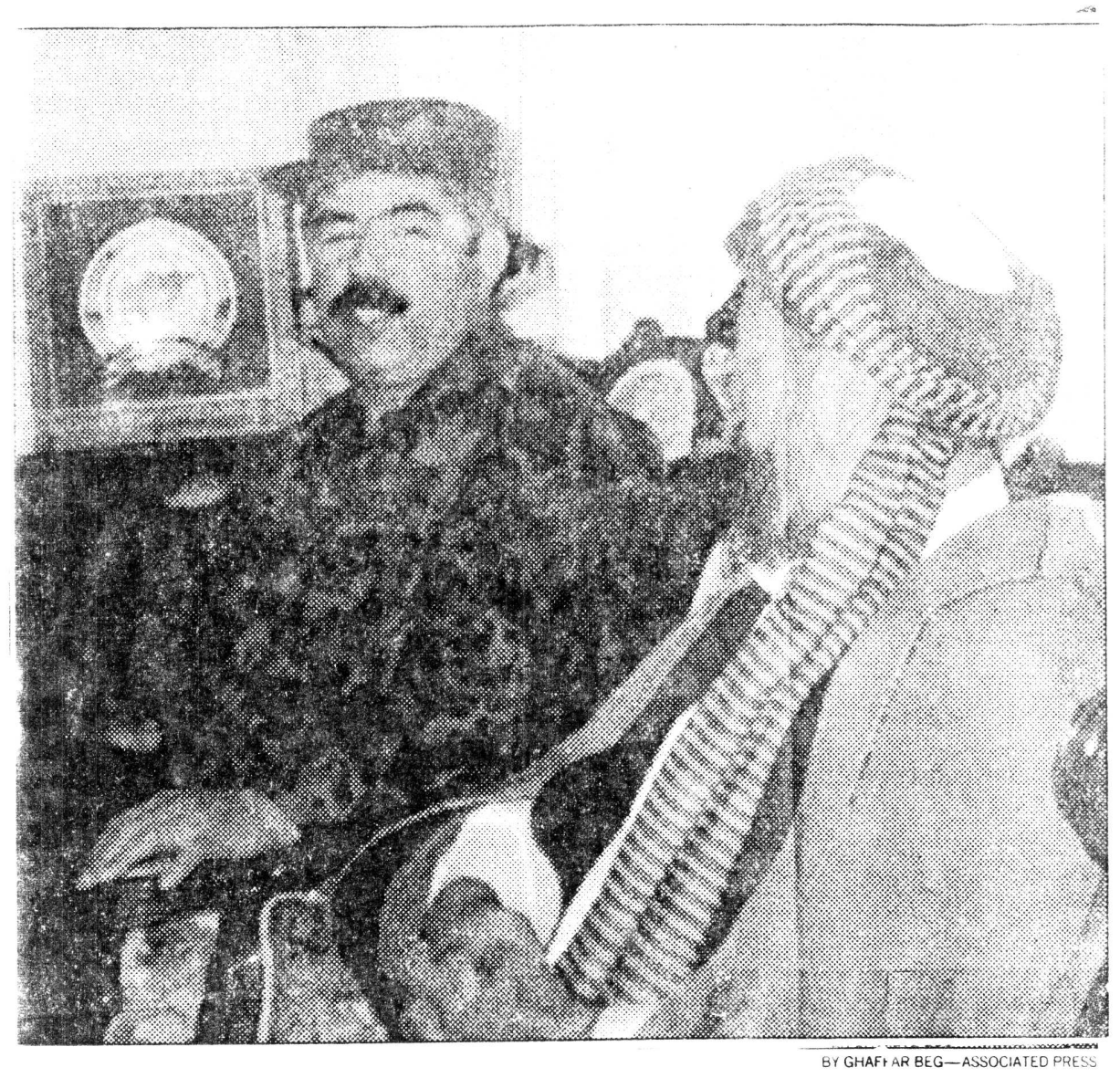

Abdurrashid Dostum, left, is shown here last October with the leader of the Shiite faction Hezb-i-Wahadat, with which his troops joined forces to fight the Taliban rebels.

to the Commonwealth of Independent itates (CIS), which comprises 12 of the 5 former Soviet states.

Russia has a commitment to defend the borders of the former Soviet Union under a CIS pact. Since November, Russia has stationed about 3,000 soldiers from several mechanized brigades in Termez, Uzbekistan, just across the Amu Darya River from Afghanistan.

Given the humiliating end to its occupation of Afghanistan and its own economic problems, Russia has not shown an eagerness to redeploy its troops in Afghanistan but appears to have supported Dostum with materiel and military adrice, according to diplomats based here.

"I don't think any of the Central Asian countries will allow the infiltration of Taliban into their region," said Turkish Consul Mehmet Samsar.

Dostum commands the most disciplined fighting force among Afghanisian's various factions. His cleanshaven soidiers dress neady in Russian unurms did louk the a regular army. His troops. errmated to number between 0006 and 609.000. have 600 to 1.500 tanks, two dozen bombers and a few Scud missile launchers.

"We are not worried about the Taliban. We're not afraid of them." said Nohammad Yusuf, Dostum's spokesman. "If the fighting begins, we are ready to defend up to our last soldier."

But the civil war has been more about money than military might. In two years, the Taliban has captured more than two-thirds of Afghanistan without fighting a major battle. It has largely succeeded by winning over militia leaders-whom it is widely believed to have bribed-and also noncombatants who have hoped Taliban rule would end economic turmoil.

In most years. fighting against the Soviet occupiers or among the factions was suspended during the harsh winter months. But relatively mild weather this year has enabled the Taliban to keep military pressure on its enemies.

The January offensive that flushed the soldiers of Ahmed Shah Massoud, who is the other major leader of the antr-Taliban alliance and was defense mirsier of the ousted government, from hal os Saral and other towns north of ibul created economic pancic Mazd 


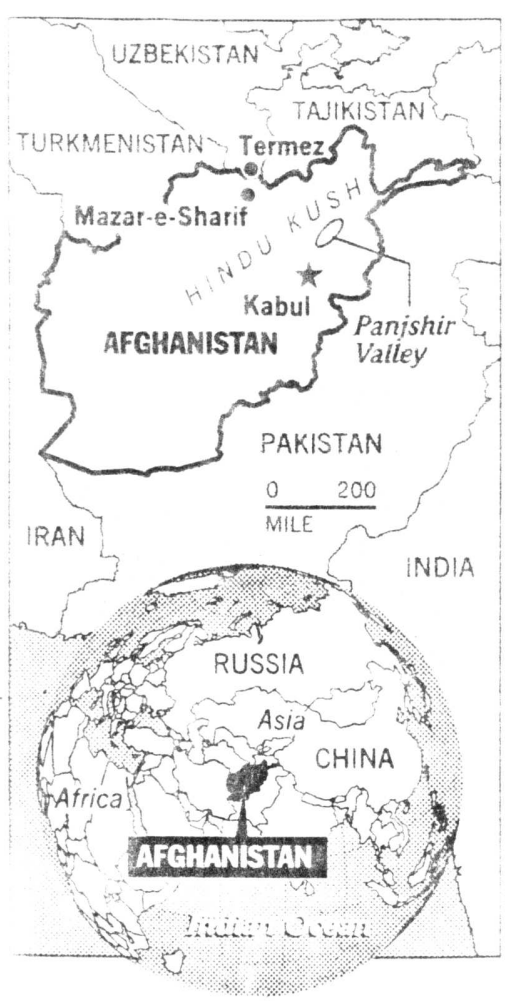

BY LARRY FOGEL - THE WASHINGTON POST

e-Sharif. The value of Dostum's curren$\mathrm{cy}$, which is slightly different from the centrai government's afghani, piummeted in the local money market. Basic lood prices jumped dramatically.

The economic squeeze has softened what last October sounded like locai residents' hard-line opposition to the aliban. "We just want reace. We like the party that will bring peace," sald Yohammad Hakim, a fertilizer factory vorker. Many Kabul residents made similar comments in the weeks before the Taliban arrived.

In the past week, the sense of economic panic in Mazar has eased. The local currency has regained most of its value, though it continues to thuctuate. Prices have come down but remain unstable. The Taliban offensive has stalled in the Hindu Kush mountains, about 30 miles east of the 10,000-foot Shebar Pass. where it confronts a Shite MusIim militia allied with Dostum's and Massoud's troops.

The return of relative economic stability may be artificial and difficult to maintain. Hohammad Arif Rahman, a maior money-changer, said that Dostum o regional government has soid
$\$ 100.000$ in the market ach day to prop up the local currency's vaiue and discourage panic buving of dollars. The nfusion of foreign currency reportediy has come from iran, which wants Dostum to help secure another trade route througn northern Afghanistan to Centrai Asia.

Anaiysts have said the other regional competitor for Central Asian trade, $\mathrm{Pa}$ kistan. has provided the Taliban with military advice through its Inter-Services intelligence agency. Among the first acts undertaken by the Taliban's leaders aiter emerging from Islamic schools in Pakistan was to escort a convoy of Pakistani trucks through western Afghanistan into Central Asia.

In recent months, the Taliban has solicited donations through advertisements in Urdu-language newspapers in Pakistan. Analysts sav that most of the militia's inancial support comes from sources in Saudi Arabia, where a similar version of Islam is practiced.

The Taliban's strict interpretation of slam wouid aiter some aspects of life in a freewheeling city where men bet lustiIy on cockfights, camel fights, donkey races and a cross between polo and rugby in which muscular horsemen carry a headless calf or goat like a ball. Alcohol, from which many devout Muslims abstain, is widely available, mostly imported beer and vodka. About 25 percent of women waik the streets without wearing a buraa, a full-length garment that the Taliban has mandated in its territory.

"If you want to drink, if you want to make fun, there are no prohibitions here," said Mohammad Hashim, who sells alconolic drinks at his small shop.

ts the Taliban marched into Kabul ast September, Massoud and his troops retreated to the safety of the northern Panisnir Valley. Because they may not have anywhere else to go, Dostum's army may have little choice but to stand and fight if faced with similar circumstances when spring arrives in April.

Travel across northern borders with Uzbekistan, Tajikistan and Turkmenistan has been tightened, although it is unclear whether new restrictions were imposed because Dostum wanted to keep anxious northern Afghans in or the Central Asian nations sought to keep any refugees out.

"We don't have any pros for anybody-not for foreigners, a t br local people. Co away." Abedian Imang the Uzbekstan consul u Mazar mequely told several men gathered out an office one moming hast weet. Washington Post 2/23
Masood shifts base as Taleban advance

ISLAMABAD, Pakistan - Ahmed Shah Masood, military chie: if Afghanistan's ousted government, moved his headquarters this week out of his Panisner valley stronghold at the approach or the rival Taleban militia, the Pakistan-based Afghan Islamic Press reports.

The AIP said Gen. Masood withdrew his headquarters to Anlarab, between the valley and the Salang Pass cutting through the Hindu Kush, so he could defend the valley and attack the Taleban.

In the past two weeks, the

Taleban have made a rapid push to the foothills of the Hindu Kush. some 60 miles north of Kabul, reoccupying positions they held in October shortly after taking the Afghan capital.

washinaton

\section{Taliban success not to create instablitity. in Sinkiang:}

ISLAMABAD (PPI) - The Ambassador of the Islamic State of AFghanistan. Mr Mufti Mohammad Masoom, has strongly contradicted an analysis in which it was clamed that the success of Taliban will create instability in the area of Sinkyang (1) Behr-e-Swadi.

In a statement issued here on Wednesday he said, the Islamic movement of Taliban is trying in create peaceful conditions and en forcing the Islamic Shatiah in $\mathrm{Af}$ ghanistan.

He said, the Taliban government will not permit any country to interfere in Afghanistan affairs.

He said nobody can prove the interference of Taliban in any other country's affairs.

He said we have a boundary line with Turkmenistan and we are living in a peaceful atmosphere.

Mufti Mohammad Masoom said that some elements want to ritch the neighbouring countries against the Talihans, but they will fail in their designs

The Afghan Ambassador ofiserved that the success of Taliban wili bring more stability and peace in war-torn Afghanistan.

$$
\text { Nation (Pakistan) }
$$




\section{Afghanistan Bracing For A New Round Of War}

By: Amir Taheri,

Arab News

As spring approaches, the snows of the Hindu Kush begin to melt, and the rival factions in Afghanistan prepare to resume their civil war. Battle lines are already being drawn in three parts of the war-torn country. In the east, a fight is expected over the control of the provinces which have changed hands several times in the past few months. At the center, the Taleban militia are bringing in heavy weapons and gunships for what they say will be "the final assault" on the Hazara Shiite stronghold of Bamiyan. In the west, forces loyal to the government of Burhanuddin Rabbani, driven from Kabul by the Taleban last September, are expected to attack Herat while also trying to gain a foothold in neighboring Badghis.

The Taleban strategy is to tighten the noose around the four northern provinces controlled by the Uzbek warlord, Abdul Rashid Dostum. There are signs, however, that Dostum's military machine may be running out of steam. In fact, some of his principal commanders are already changing their afghanis into US dollars and sending their families into next-door Uzbekistan. A recent visitor to Mazar Sharif, Dostum's capital, reports a rising mood of "anxiety and panic". She says she saw lorries carrying the belongings of senior military commanders toward the Uzbekistan frontier.

If Dostum's military machine were broken, the Taleban could then turn their energies against the forces of former Defense Minister Ahmad Shah Massoud in the Panjsher Valley, his home province north-east of Kabul. Massoud's forces were recently involved in actions against the remnants of Hekmatyar's Hizb-e-Islami. This confirms that though Hekmatyar remains nominally the prime minister in Rabbani's government, he is deeply distrusted by Massoud. The possibility that Hekmatyar might switch to his own ethnic Pushtun camp, now led by the Taleban, cannot be dismissed out of hand.

The anti-Taleban group now appears at its weakest since it lost control of Kabul. Can the Taleban therefore achieve their declared aim and seize control of the nine provinces still outside their control?

Their strategy, upon close inspection, fails to take certain facts into consideration. Both Dostum and Massoud, for instance, could be supplied and supported by their respective ethnic brethren in neighboring Uzbekistan and Tajikistan and thus continue fighting indefinitely. Their allies, based inside the Iranian border close to Herat, could receive aid from Iran and threaten the Taleban's own stronghold at Kandahar.

Norbert Hull, the German diplomat representing the United Nations in the stalled peace talks in Afghanistan, says that the war could go on for many more years. This is, unfortunately, not the prediction of a pessimist. War has been Afghanistan's main "industry" and single biggest source of employment for the past 20 years. Even if the leaders of the two rival factions agree to make a deal, scores of lesser guerrilla leaders will make sure that fighting continues. In fact, talking of "two factions" is itself a mistake. There are more than 100 armed groups who put their services up for sale to the highest bidder. When one leader has more money than another, the local warlords rally to him. When another appears with larger greenback-filled suitcases, they then rally to him. In the past two years, the biggest dollar-filled suitcases have belonged to the Taleban who seem to control an endless flow of cash.

Where does the money come from? Some of course comes from a dozen or so countries which, for various reasons, are interested in having a foothold in Afghanistan. But a good part has 
always come from drug smugglers and other criminal organizations operating in both Pakistan and Afghanistan. "Unless the sources of cash are found and blocked, the war in Afghanistan will continue," says a former Afghan diplomat, "The United Nations alone cannot end the fighting. The major powers, especially the United States and Russia, must jointly sponsor a realistic peace effort."

In the meantime, the Taleban are trying to impose their vision of "the perfect society" on the areas of Afghanistan under their control. This especially affects the cities, notably Kabul, which includes among its inhabitants a strong, partly-Westernized middle class. The countryside is less affected simply because the Taleban lack the men to control each of Afghanistan's estimated 22,000 villages. In any case, most rural areas are controlled by local warlords who subcontract their services to the Taleban in exchange for autonomy in their own area.

The Taleban are therefore concentrating their attention on destroying the urban middle classes. This has already begun by excluding all women from employment. This week a new stage in "class purification" was launched by the Taleban who have decided to shut down large segments of the civil service. This move will deprive much of the middle class not only of a job but also of a status in society. To the Taleban, the middle classes are either former Communists or weaklings fascinated by the West and its values. Thus Taleban spokesmen make no secret of wishing these "corrupters of the earth" either physically eliminated or forced to quit Afghanistan. The war in Afghanistan then is not only about who controls how much territory. It is also about the kind of society that will emerge in that country after two decades of bloody war. AFGHAN NEWS SERVICE $3 / 26$

\section{Anti-Taliban forces reopen offices in Pakistan}

\section{From Behroz Knan}

PESHAWAR: Several Afghan muianiceen groups, including former president Burnanuddin Raboani-led Jamait-Islami, nave reopened ther offices in NTWP after the change of government in Pakistan.

Tnougn no major shift in isiam. abad s poin on the Afghan issus is in sight. the anti-Taliban forces have been encouraged to start their political activities in Pakistan. The lates: develooment is the reopening of Jamiat-i-isamis office at Chamkan refugee camp. The office nas aiready beer! used by the party during its more tran 15 years stay here

$\therefore$ local Pushto newspaper nas even pubiisned the statement of janiat s spokesmar Abdul Baseer. ciaming lo have contacted the deposed Afinan presidert Rabbani inside Afgnanistan througr: wreless froni its Chamkan offic. The crarge. Afgran sources said, came after Nawaz Sharif's address to the nation in when he briefiy touched the issie, sayng Fakistan has I" favounte among various Afghar zrouns
The other deveiopment is the tels phonic press conference in isiamabad by Hezb-i-Isiami chief and former prime minister Gulbaddin Hikmatyar from Tehran. Hikmatyar is trying to versuade Islamabad to weicome him. The Hezb chief is stated to bo not feeling easy in Tenran. However. no response nas been given by Islarr! abad so $\mathrm{fa}^{-}$due to the objections raised by Taliban. The Hezb-i-Islami has not closeci down the office and continue to rork in Peshawar.

The ousted Eastern Shura. led by for Governor Nangarhar Haii Abdul Qadeer, has aiso opened its office at the vorder town of Landi Kotal. It is to be recalled that Qadeer was summoned by officiais of the secret agercies in Pesnawar last month asing him not to issue statements in support of the Kunar rebellion

The dismembered tiangarnar Snura favoured Malik Zarn chatienging Tailibar: rue over the Afgnan border provune win Pakistar.

Interestingly: the small Snilit Hezt---Trandat group led by Muram. mad thing is also reported to have opened itis oflice in Peshawar. The vary dine nublish a newspaper from here as well. The maior Hezb-iWandat. led by Karim Knalili, is aiready naving its office in Peshawar and representatives in Islamabad.

Talibar have several offices in Pakistan pius the isiamabad Embassy and the consulates elsewnere in the country.

Professor Sayyaf, currently residing with commanders in Kunduz province, has reportedly given up the idea to shift into Kunar. Commanders belonged to Sayyaf's Ittihad-i-Islam in Kunar have reportedly expressed inability to provide sheiter and sectrity to their party chief in Kunar. It is also reported that Sayyaf was se. cretiy supporting the Kunar uprsing agains Taliban.

The rest of the muianideen ieaders, inciuding Pir Syed Ahmad Gillani, Munammad Nadi Muhartmadi and Sibgnatullar Muiaddaci. are stanng in Fakistan and never shifted tneir famiiles to Afgnanistan. Majonty of the Afghan leaders who were provided snelter in Pakistan soon after the Sonet occupation of Afghanistan chose to snift their families to their country when Kabul fel to muahideen in 1992 


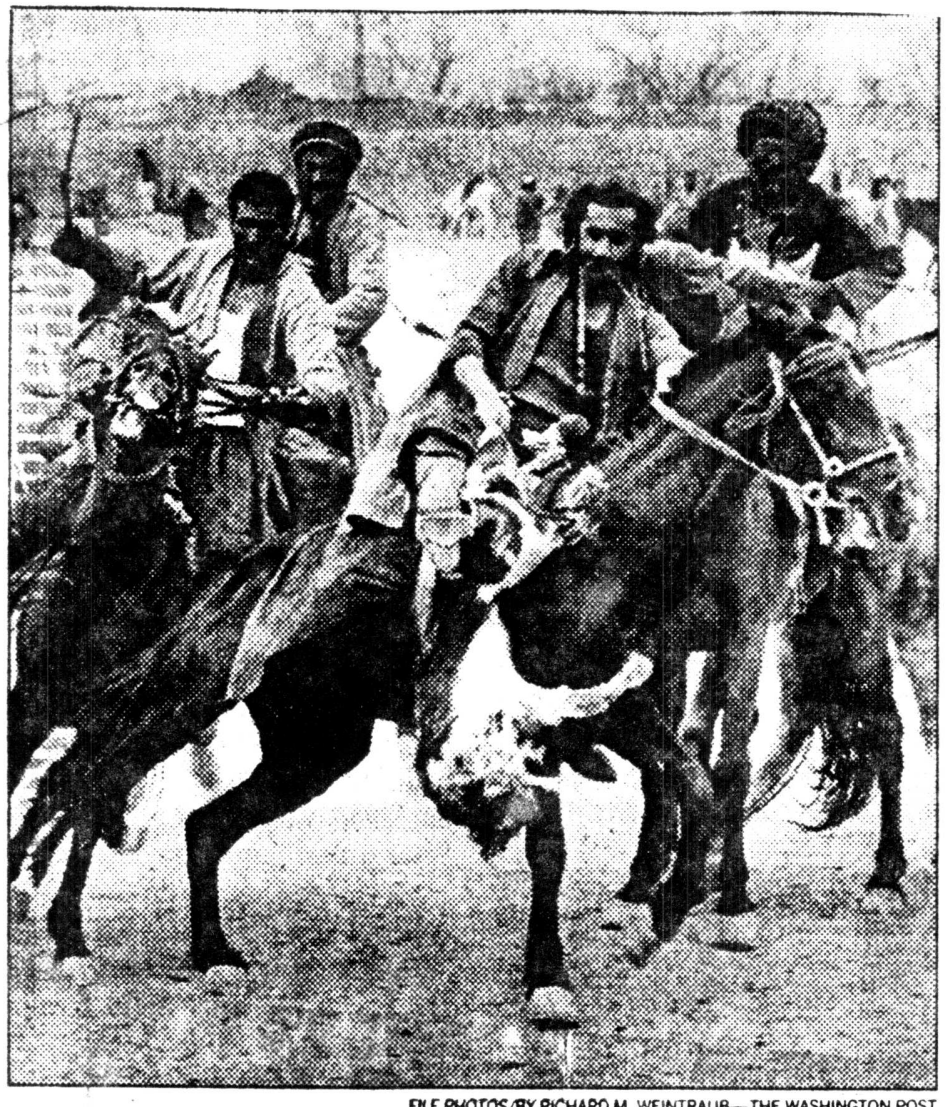

FLE PHOTOS/BY RECHARO M. WEINTRAUB - THE WASHINGTON POST The Afghan sport of buzkashi is a cross between polo and rugby, but with one major difference: A headless farm animal is used as a ball.

\section{Getting Their Goat}

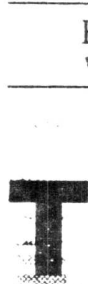

By Kenneth J. Cooper

Washington Post Foreign Service

\section{MAZAR-E-SHARIF,} Afghanistan

$\mathbf{T}$ game began with an unusual face-off. About 50 horses, rearing into the air and kicking up dust, converged.around a chalked spot at cha end of a dirt field. Their

zular riders leaned over and reached down in a rough scramble to grab the ball.

"But the ball was not made of leather, tanned and inflated. It tas the mother of all game balls - the headless carcass of a black calf

This was buzkashi, the nationl pastime of Afghanistan, a blood sport of strength and unbridled aggression that resembles a crude cross between polo and rugby. Oral tradition holds that buzkashi, which literally means "grabbirig the goat," originated centuries ago among nomadic tribesmen of Central Asia and Mongolia, who used the bodies of captured enemies instead of tarm animals.

These days, fewer buzkashi atches are held in Afghanistan, ut not because of anv moderniz.
Now the game is plaved only the northern provinces that remain outside the Taliban's reach, notably those controlled anti-Taliban faction leader Abdurrashid Dostum and the ousted Afghan government of former president Burhanuddin Rabbani. The burly Dostum, a general in the pre-Rabbani, Soviet-backed regime, has his military headquarters near Mazar-eSharif and occasionally rides in buzkashi matches in his home town, Sheberghan, near the border with Turkmenistan. Matches are also held across the southern border in Peshawar, Pakistan, where thousands of Afghan war refugees live

"This is the traditional play of Afghanistan. This is the national play. We enjoy it," said Bashir thmad, a tan who watched a recent match here.

After saying afternoon prayers in the mosques, local men streaned toward a windswept field on the plains that surept theld on the plains that sur- or riding in taxis, buses or military vehicles. Several hundred spectators, wrapped in woolen shawis, huddled on a small concrete grandstand. Others watched-like patrons at a drive-in movie theater-from vehicles parked atop dirt mounds on the sides of the rectangular field

Roaming vendors hawked popcorn, roasted lentils and circles of flat bread from woven baskets. Men kneit on a carpet behind the grandstand and laid down bets on a game of chance plaved with six oversize dice. In the grandstand, spectators made wagers on the various horsemen.

To win a buzkashi match, horseman must lift the headles. carcass from the chalked spot, lug it down the field to a flag post and then return it to the original spot while his mounted competitors try to snatch it from him. Riders and horses train for years to reach a competitive level in the sport-which requires strength as well as skill because the animal carcasses can weigh up to 100 pounds.

Ten minutes after the faceoff. the scramble of swarming horsemen had moved the calf laterally to one corner of the field. Suddenly, a rider spurted away from the pack, leaning precariously as

he dragged the carcass by its leg. Several horses galloped alongside as their riders unsuccessfully tried to snare the dangling animal.
Upon reaching the flag, the horseman dropped the carcass. raised his arm in celebration and rode to the grandstand to collect gifts of monev from appreciative fans.

The horsemen are

two teams, but in this only evidence ot team when several horsemen formed a line to block another rider from dropping the carcis

chalked spot. The reteree an derly man mounted moving donkey, make sure the carcass

Otherwise, the

match was a unruly game of grab and dash, with the horsemen try ing to out-muscle each other prevent a winning ride.

In some ways, the chaotic competition seemed a metaphor for the ongoing ciril war in Afghanistan between ethnic-based factions: They test each other strength in skirmishes and then ride off to fight again another time, making it hard for any militia ultimately to settle the eightyear-old conflict.

\section{THE WASHINGTON POST}

MARCH 10, 1997

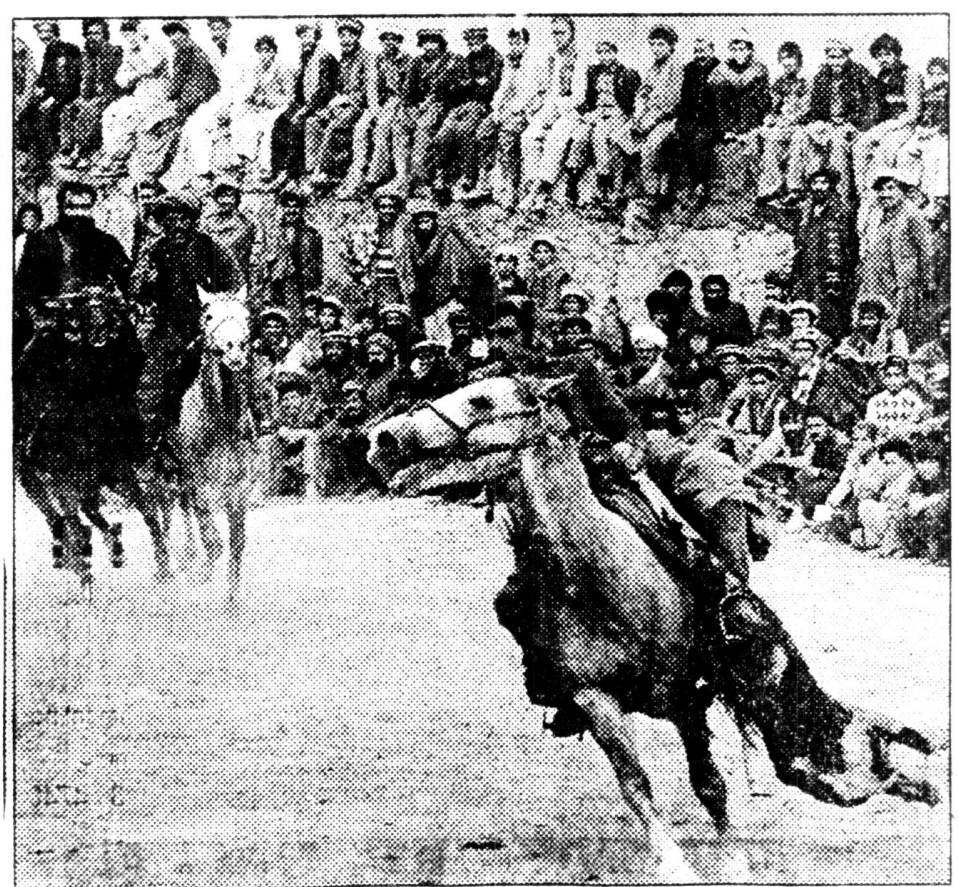

A rider breaks free from competirors, dragging the animal by its leg. 
PAYDAY FOR KABUL'S CIVIL SERVANTS

(From a Reuters report 11/3/96)

Throughout the Afghan capital civil servants were counting huge piles of 50 Af. banknotes. They had just received their lst pay in 2 months. 50 Afs. is worth a third of a US $\$$. The average monthly pay of a civil servant in Kabul is 102,000 Afs., or $\$ 6$.

Senior staff members earn the equivalent of between $\$ 12 \& \$ 15$ a month.

Analysts say the suspected cause of the late payment \& the small denominations is that Rabbani's gov't took most of the contents of the central bank with them when its members fled Kabul. The currency is not printed in Afghanistan $\&$ analysts suggest that until the Taleban are recognized as the rightful gov't, they will have difficulty persuading the printers to provide them with more currency. Many shopkeepers will not accept the notes for anything but the smallest purchases. Money changers charge $20 \%$ to change the small notes into $5,000 \& 10,000 \mathrm{Af}$. notes.

\section{NO NEW YEAR CELEBRATIONS}

(From a Reuters report 3/20/97)

Taleban cancelled the Afghan New Year public holiday \& banned all New Year festivities, saying celebrations of any kind are against Islamic law. The Taleban Supreme Court said: "As all days are the same \& there is no difference between the lst \& the last day of the month, \& also because Nowruz day has no particular significance except celebration, Nowruz has been prohibited according to Sharia law. Therefore, organizing special ceremonies on this day, picnics, arranging special food or declaring the lst day of the New Year a public holiday are against sharia rulings."

\section{AFGHAN WINDOWS}

(From Reuters 3/19/97)

Kabul residents must screen windows in their homes so that women cannot be seen from the street. Householders have until $4 / 9$ to comply with the rules which require them to paint any clear glass or replace it with opaque glass up to a height of 6 feet from the floor, especially on the 2 nd floor where the windows pose a threat to the neighbors. "The face of a woman is a source of corruption for men who are not related to them," said a Taleban official.

TALIBAN BANS FOREIGN BOOKS

(From an Associated Press report 2/27/97)

Taliban banned the sale of books \& magazines published outside Afghanistan because they might contain information repugnant to Islam, according to Information Minister Amir Khan Muttaqi. This is in addition to the ban on using paper products which might be made from recycled pages of the Koran.

IRAN ACCUSES TALIBAN OF SMUGGLING AFGHANS (From an AFP report 2/18/97)

Iran accused Taliban of smuggling Afghans into Iran, for a reported $\$ 200$ a head. Iran is trying to repatriate 300,000 Afghan refugees and accused Taliban of "preventing" these efforts. An Iranian immigration official revealed plans to return 200,000 Afghan refugees through Turkmenistan \& some of the southern border regions. About 1.5 million Afghans are in Iran. But because of high unemployment in Iran, the Labor Ministry recently banned the hiring of foreigners, a measure mainly affecting Afghan manual laborers.

\section{TALEBAN TARGET HAIR \& CIGARETTES}

(From Reuters 2/15/97)

The Taleban are expelling people with untidy hair, without beards or smoking cigarettes from the army \& gov't ministries. A special commission has been set up to purify the army \& ministries \& bring them in line with the Taleban interpretation of the Sharia. It is also expelling under-age fighters from the armed forces \& sending them to religious schools for further education. The "clean-up" was necessary because undesirable elements joined the Taleban as they took over the country.

\section{WOMEN'S FACES "SOURCE OF CORRUPTION" (From Reuters 3/18/97)}

An official in the Atty Gen'l's office of the Taleban said: "We consider that a woman should have her face covered when she goes outside, because the face is the point of attraction. If you read books, poets are always talking about the attractiveness of eyes, noses \& lips."

\section{TRAFFIC TICKETS (from the NYT 4/19/97)}

In the lst 3 months of this year. cars of UN diplomats representing Afghanistan have received 46 tickets \& owe New York city $\$ 2,820$. 


\section{Iranian Support Lends Increase To Afghan Currency Value In North}

KABUL, Feb 17 (AFP) - Financial support from Iran has spectacularly increased the value of Afghan currency used by northern opposition leader General Abdul Rashid Dostam, travellers reaching Kabul said Monday.

"The afghani, which had decreased in value to over 120.000 to the dollar, is now worth around $18,000, "$ a Western traveller told AFP.

The dramatic increase in value of the afghani over the past two days has been attributed to a huge buying operation by a bank in Dostam's northern capital of Mazar-i-Sharif.

The massive influx of United States dollars -- which unconfirmed reports from both Kabul and Mazar-i-Sharif say comes from Iran -- have been used to stem the nose-dive of Dostam's rapidly In Taliban-controlled Kabul, the afghani is currently traded at around 22,000 to the dollar. The depreciation of the afghani in Dostam's northern fiefdom was the cause of much financial hardship for the civilian population. It also weakened the morale of Dostam' fighting force.

"There is a much more confident mood in Mazar now," the traveller said.

The expected drop in food prices following this meteoric increase in the value of the afghani should help to stabilise Dostam's administration which now faces a looming military threat from the
Taliban.

Iran has also reportedly airlifted large amounts of food supplies to Mazar-i-Sharif and donated arms and ammunition to Dostam's ally, Ahmad Shah Masood.

There are also unconfirmed reports that military support from Russia in the form of heavy armour has reached Dostam and Masood.

"Fifty tanks are said to have been given by the Russians and more are promised, but no Westerner has actually seen them," the traveller added.

Masood, military strongman to ex-president Burhanuddin Rabbani, who was ousted from Kabul by the Taliban September 27 last year, has recently suffered massive territory losses to the religious militia.

Russia, which still considers its strategic borders to be those of the now independent central Asian republics of the former USSR, does not view the northern advance of the Taliban with pleasure.

The Afghan Daily News - AFP

\section{Refugees must return to help Afghan economy- UNHCR}

KABUL, Feb 17 (Reuter) - Central Afghanistan's economy will be severely affected if more than 100,000 people displaced from the plains north of Kabul are not allowed to return to their farms, a U.N. refugee official warned on Monday.

'If these people are not allowed to return home and farm it will have a serious affect on (central) Afghanistan's economic situation, which is already disastrous," said Terry Pitzner of the United Nations High Commissioner for Refugees (UNHCR).

He told journalists that more than 105,000 people had come to Kabul from the fertile Shomali valley north of the city.

Some were fleeing fighting between the purist Islamic Taleban and opposition forces but many more were forced to move when the Taleban completed their conquest of the valley three weeks ago.

The Taleban have cited security concerns for a policy of moving civilians from the villages and towns of the Shomali valley and not allowing them to return.

The Shomali valley is an important supplier of food to Kabul's hard-pressed population and parts of central Afghanistan.

Food prices in the city have already moved beyond the reach of many residents. The United Nations estimates that almost half of Kabul's inhabitants receive some sort of food relief from international aid agencies. 
Pitzner said he had asked Mullah Mohammad Rabbani, the senior Taleban representative in Kabul, to allow the refugees to return.

We pointed out that these people need to start ploughing and pruning. He said that they would perhaps be allowed back within a month," Pitzner said.

The UNHCR says that of the displaced people from the Shomali valley sheltering in Kabul, some are living eight families to a room in unused schools.

Pitzner said the UNHCR had organised a relief distribution for 1,250 families -- approximately 7,500 people

-- who had been forced to flee to Kabul.

He said if residents of the Shomali valley were forced to leave their fields fallow it would exacerbate the situation. "It would further inflate food prices in Kabul and elsewhere," he said.

\section{A Prisoner of the Mujahedin}

Several thousand political prisoners are being held in labor camps in the Panjir Vaiiey. Under blazing heat in the summer and biting cold in winter, they mine precious stones. emeraids and lapis lazuli. The proceeds from the sale of the gemstones abroad, hundreds of millions of dollars, flow partiy into the central government's war chest and partly into the pockets of Shah Massoud, Kabul's strongman. The Panjir Valley is his strong. hold; it was there that he gained his reputation as the "Lion of the Panjir" in the struggle against the occupying Soviets.

Among the prisoners is a man named Hafiz. In 1992, when General Dostom, who rules a part of northern Afghanistan, pulled off a coup against President Najibullah and took two thirds of the air force with him back to his home territory, Hafiz joined him. In Dostom's service, as a daring pilot who flew the most dangerous missions, he rose to the rank of three-star general. Hafiz was driven largely by hatred of the Islamists. Shortly before he was taken prisoner about a year ago, he boldly stated that communism had coilapsed and that, at the controls of his bomber, he was helping insure that the fundamentalists would also fail to overrun his country. When flying missions against an enemy base, Hafiz would heap the worst curses on the heads of his opponents as the dove boldly earthward. Nearly all Afghan pilots have had the same training, and Hatiz generally knew exactly who was down there beneath him. With some of them he had trained in the Soviet Union, with others he had flown missions in Jalalabad in 1989 against the rebels, causing thousands of deaths among the mujahedin. Today Afghanistan's endless civil war has turned old air force buddies into enemies. Believing him to have remained a Communist, his former comrades hate Hatiz as intensely as he hates the mujahedin.

Hafiz's plane was reportedly hit by a Stinger missile. After parachuting to safety he was taken prisoner by Massoud's men with a bullet in his leg. Hafiz is a valuable hostage, a good prospect for a prisoner exchange. Meantime he languishes in the not-too-gentle hands of the National Secu $n y$, the intelligence arm of the mujahedin

The Afghan Daily News - AFP

\section{Kabul University officially opens, girls unlikely to attend}

KAPII: Kabul loniversity apened Smolas with a Taliban-sponsored of-

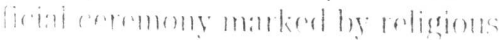

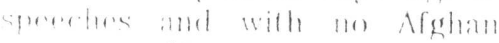
wnom in sight

"In the forme if we have enomgit resomeres we will have separate or uration for women," Manlavi Hamdullah Numani, acting Minister of Higher and Vocational Edmeation told enenters.

Women have apparently not been oflerially hamber from Kabul (haversity (Kl') he the Taliban. but their atfombance is anditional on segregat fimin.

The main problem is a lack of besemeres - wo need separate facultere and separate hostels," the higher enhoation ministor sairl.

flemple a Talihan ban on wement workings in molili. Numant satid, as in the rase of the medical sector. womm! would be allowed to be paciers as woll

KU Rector, Dr Amir Slath Hassalyat stated hat bo of his :360 teaching stall were women, int nome were seen at the thee-hour lomg opening ceremony presided over by several Taliban ministers.

We will lose 1,400 teaching homs per somestre without these fi() women," Hassanyar sairl.

The fremede ifenatement of the Fonenly of langsulgses would remain

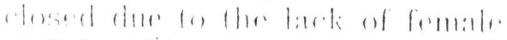
chall, he didedert

In ardition he said there was curwhlly a seat lark of facilities at KU heralse the campus suffered immense damage in the years when it was a fromtline botworell warring destam fartionse

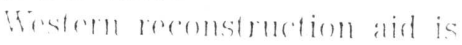

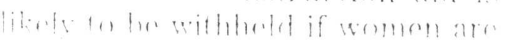

kept out of the mirersity aterending to the expatriate humanitan inn an (o)mmunily in Kabul.

It was not deat how the Talihan would reate a segregated redurathen system for women, but neen thon there were certain subjects fommins could mot study, Numani moterl.

"They are not allowerl lo stouls engineering, but they ran stuty medicine, education, moral ami other social subjects, "he sairl.

A special ruling has bern mate (o) allow faculties to sidestey the ham on illustrations on photonsumben living forms, he implied. ply.

"Il will be allowed," le and sint

The dissection of human engeses was another tricky question fietitod by the higher echuation ministe?

"In the past when this jontre a." referred to religions soholats, wh reived a negative answer," he sain

"But some of them have promised to re-examine the issm. he added.

Ilamelullati Numani said for 1 (n) the Taliban have allocated a butgent of around 700,000 US dollars for Ki] and other higher erlucational institntions, including Kabul Polstechnis.

With the absence of female students, mone of whom have resis tered so far. Hassanyar said he we pected 5.00() males to attond Kl

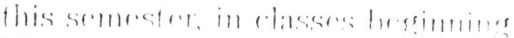
Mondiay.

Hassanyar, who has a lli ll in ecology from colotarto State Iniversity but eams a monthly salary of just 32 dollars, lamented the fart that so many highly oflucouten Afghans had left the (e)motrs in a brain-diath due to the incpesant Mghting- - 'T' NEWS (Pakistan 
Veariy two

decades of war in

Afghanistanhas

iardened the West

to the terrible

suffering and

human rights

abuse which still

continues. Amid

international

media fatigue

\section{MichaelKeating lackles the mammoth task of drawing attention to the plight of this war weary nation}

Dur argument was hat the people of Afghanistanshould
Surviving a media vacaum

But the odds against drawing attention to the needs of ordinary Afghans are ormidable. Why should anyone want to give money to a country whose authorities abuse human rights, impose purdah on women. and deny education to girls? And isn t aid just going to be wasted if the war goes on?

What s more, the UN has an uneven. often appalling record, in giving prioriy to communication. The UN's releance overall is lost on most people. and the funds and personnel available ior communication and PR work. even when the cause is indubitably worthv, is tten minimal.

In normal circumstances, one might

uppose that a place to start would be with the Afghans themselves - after all, they have most to gain, or lose. But most professionals, including academics, journalists and businessmen. have left the countrv. The media is defunct: local radio issues propaganda. and there are no newspapers. Forget TV. As for the Taliban themselves, perhaps. just maybe. one has to ask if they might see the merits of tempering their behaviour in the interests of getting international aid for the welfare of their people?

The Taliban are just the latest phenomenon in an ugly war that is now entering its 18 th year. The Soviets invaded Afghanistan at Christmas 1979; for 10 years. mujahedin of various shades battered them until Gorbachev pulled them out. The war against the Sovietinstalled government headed by $\mathrm{Na}$ jibullah (whose corpse was later strung up by the Taliban to advertise so effectively their accession to power) went on until 1992 when the mujahedin finally took control of the whole countrv. But instead of peace. this was the cue for the mujahedin to tear themselves - and what was left of the country - apart.

\section{The beginning of 'purification'}

Popular disgust at the behaviour of the mujahedin was the curtain raiser for the Taliban, young Islamic student zealots determined to 'purify' Afghanistan - if not the world - and rid it of rapacious. self-serving warlords. Two years after cur tirst anpearance on the scene. they simply because yet

another bunch of

ideologues have

takenpower now control three-quarters of the country and have brought. despite therr appalling human rights record. a degree of iecurity and order in their wake. But as anyone who has been in contact with them has discovered. thev are largely illiterate. oblivious to the wav the rest of the world sees them, and far more focused on fulfilling what they see as God's will than tending the welfare of their people. Negotiating with them is like grasping smoke. Hardly reliable as allies in attracting aid.

This is all the more frustrating as the need for aid is not in doubt. Perhaps a million have been killed. leaving millions of widows and orphans. Three million people are still refugees or internally displaced. The country has more landmines littered around it - 0 million - than any other country in the world. One in ten Afghans is disabled or emotionally impaired. The country has the highest infant mortality rate in Asia and the lowest literacy rates. Perhaps half a million people are dependent on food aid, and tens of thousands may be severely malnourished.

My hardened journalistic friends told me that the only way to raise sympathy levels for Afghanistan would be hy showing images of utter miserv, preferably starvation. Public immunity - or editor fatigue - towards humanitarian need is growing, and the competition from Zaire. Bosnia. Somalia and elsewhere left no other option.

But I faced at least two problems with this suggestion. The first is that the misery in Afghanistan is of a different order: it is protracted, endemic and relentless. not dramatic and mediagenic. There are no African-style 'biblical' scenes in Afghanistan. although as winter takes hold. something approaching them may occur. The second is that I couldn t do it. For decades. Afohanistan has enjoyed the reputation as being full of tough. proud. hardened people and promoting an image of Afghans as pathetic. begging and desperate would do them a long-term disservice, one which might take vears to reverse.

Neither image is fully accurate. but of the two the former is healthier both for the Afghans self-worth and as an ingrelient in rebuilding the country when.

snmail noace is achieved. 


\section{Reuters comes to the rescue}

My starting point was to find out what was going on. It was hard to get a seat on either of the two UN planes that crisscross the country, such was the competition from journalists. including seemingly every self-respecting war correspondent in the world (two weeks later. the whole lot had left for the Rwanda/Zaire border). Few were interested in the humanitarian or aid story the Taliban, their abuse of womens rights and the battles to the north of Kabul more than filled the horizon.

The head of the UN humanitarian office in Afghanistan turned out to be fully supportive of suggestions I made regarding PR. Using his authority, I convened a group of media oriented UN officials to work out what we should do. Everyone agreed: there was not the time. money or support for a full blown communication strategy before the launch of the appeal. Any thoughts of doing research into perceptions of Afghanistan, advertising, organising special events in key western capitals and other ideas were out.

Instead, our first priority would be to get images of humanneed out, plus a story to hang them on. The launch itself and the international meeting were the obvious candidates, particularly as the meeting was already seeping controversy.

A chance encounter with a Reuters TV journalist in Mazar-i-Sharif helped us get going with the images. She was covering the fighting but knew little about the humanitarian angle. I was soon in touch by sat-phone with her editor in Bangkok.

Working through their closest bureau chief in neighbouring Pakistan. Reuters agreed to shoot some footage for worldwide satellite distribution on the day of the launch and the international meeting on Afghanistan as well as to produce an edited eight-minute video for non broadcast use by the UN. This agreement was reached after painless negotiations with Steve Garvey. manager of Reuters Corporate TV in London, and with Tony Davenport. Asia editor. The UN would pay a modest fee to cover costs and help with logistics, but this was not going to be a VNR - now a dirty word. it seems. with some broadcasters. Rather. the UN would help make it possible for a news agency to cover a story which otherwise they would not be able to.

\section{Overcoming eleventh hour hitches}

With some help from UN colleiagues. I quickly drew up a script for the eightminute version which started 'Images of bang bang. Voiceover:"Afghanistan has been at war ..."' and went on to touch upon both the main problems facing ordinary people 'fighting a war for survival' and to address the obvious questions about human rights and the wisdom of providing aid to a country at war.

Our argument was that the people of Afghanistan - especially the women - should not be penalised at the hour of their greatest need simply because vet another bunch of ideologues have taken power, and that if anything. more aid funds, not less. are needed. We also showed images of aid projects which are working well despite the war, emphasising the amazing ability to maximise the impact of the paltry aid they receive.

The logistical problems getting the footage almost defeated us. Helping get the cameraman a visa, for example, was tough, not least because the Taliban have begun to take a tougher line with journalists. In one location. Herat. they refused to let him off the plane. I arranged a day of interviews in French. German. Spanish, Japanese as well as English with various people knowledgeable about the aid scene and at the last moment found myself cast as the off-camera interviewer.

While this was going on, disaster of sorts struck - the Pakistani government objected to the Indian government being asked to the meeting on Afghanistan - which was to be held in Peshawar, on the Afghan border, but on Pakistani soil. The meeting would have to be relocated and postponed. as the UN was not prepared to de-invite the Indians. This was a story, but the wrong one. Days of indecision and confusion followed, but we pressed on with our plans, judiciously so, as it turned out. UN HQ in New York decided to go ahead with the appeal and postpone the meeting until 1997 - a great pity for us. but we counted on the launch still being enough of a story.
We got the footage. rushed it to Londion on the last possible flight where it was edited by Tony at breakneck speed. The eight-minute version was then couriered to New York. Geneva and Pakistan for the UN launch ceremonies. and the longer. less structurec version with a $B$ roll was put out on the Reuters feed on the morning of the launch of the appeal, 3 December. It was picked up all over the world, in cluding by BBC World. Euronews. the Middle East Broadcasting Corporation and elsewhere.

\section{Awaiting an uncertain future}

Simultaneously, the logistics being impossible from Afghanistan, we issued press releases and an executive summary of the appeal document to ail prominent international journalists in the region, including the internationai radio and wire services.

In Afghanistan, we organised a number of launch ceremonies. including oneat a prosthetics workshop in Kabul. which were well covered in the wire services. The reports were widely used in Europe, Asia and elsewhere - though scarcely in the British media, which was disappointing. I am still not sure why.

Will this effort translate itself into money for aid programmes? It is too early to say. Certainly, at the appeal launch in New York. hosted by Yasushi Akashi. Under Secretary for Humanitarian Affairs, governmental representatives were said to be impressed by the footage and by the argument, which they probably had not heard before, that aid should not stop because of the Taliban. The Norwegian government pledged $\$ 1$ million $(£ 650,000)$ on the spot. which was a good opener.

Did our efforts amount to communication strategy for the people of Afghanistan? No, but it was a start. The hurdles to getting the world to respond fully to the needs of the Afghans are just too high. My hope is that the UN and others will nevertheless provide the resources and authority to allow us to develop a campaign on their behalf, and the success of our efforts so far look as if they might result in funding for a proper campaign being made available. And who knows, maybe some of the hurdles will be lowered - the Taliban may disappear as fast as they came.
PRWFEK (TONdOR) IO JANI:ARY 1097 


\section{One Step Forward, 2 Steps Back}

\section{Fiscal Fandango Damages an Emerging Uzbek Market}

By STEVE LeVIrJE

TASHKENT, Uzbekistan - Steve Shaulis is selling the last of his seedless raisins, settling his debts - and getting out of this central Asian country.

It isn't that the adventurous 33-yearold trader has soured on the whole rollicking fringe of the world's emerging economies. On the contrary, Mr. Shaulis, of Vero Beach, Fla., is headed to the nearby wilds of Afghanistan and western China, where he expects easier profits.

After a three-year effort to build United States or European markets for Uzbekistan's bountiful fruit, Mr. Shaulis says the problem here is not mere third world chaos and inefficiency. No, he says, it is the Government's gangland economic style, in which Western invest ors are lured with sparkling promises. then in effect rolled in the back alley.

"Until they free their economic policy," says a smarting Mr. Shaulis, sipping

\section{Roads in Afghanistan in deplorable condition}

ISLAMABAD (KPI) - Years of fighting has damaged roads in Afghanistan. Little work has so far been done to repair the dilapiciated roads in different parts of the war : attered country.

A BBC correspondent who visited some parts of Afghanistar reports that the 500 kilometre road between Kabul and Kandahar is in bad condition. In the past a vehicle had to reach Kabul from Kandahar in six and half hours but now it takes 26 hours.

The road between capital Kabul and Kandahar has almost been totally damaged and only a few portions of the road are in good condition. Taliban have repaired section of the road from Maina to Ghazni.

The residents of Zabul, Ghazni and Wardag areas complain that neither the relief agencies nor governments in the past paid attention to repair of the damaged roads. They say that Taliban, who control the ared have also did nothing for the reconstriction of the road. Despite dilapidated position of the road vehicles including buses, trucks and coaches are plying on the road and transport is available on routs between Kandahar-Kabul and (Shazni. Trucks, loaded with timber, come (0) Ghazni from Paktiya and unar and later enter Palistan. NATION coffee in a hotel lobby, "this is going to be a backwater.'

Just a few months ago, this conservative nation of 23 million people was a darling of Western investors. After years of continued restrictions after the 1991 Soviet breakup, President Islam Karimov at last opened up to a surge of Western products. Economic and human rights changes repaired a cool relationship with Washington, and in June $\mathrm{Mr}$. Karimov was rewarded with a longsought White House visit.

Today, however, there is scant evidence of the short-lived boom that $\mathrm{Mr}$. Karimov set in motion, one that had enlivened this sterile, Soviet-style capital of hulking concrete office buildings and apartment blocks.

Large Western multinationais, like British-American Tobacco and Newmont Mining of Nevada, are still doing well here, diplomats say. But the International Monetary Fund, disappointed with Uzbekistan's runaway monetary growth, has suspended the republic's $\$ 180$ million loan program. And many executives from small- and mediumsize Western businesses say they are freezing their investments or, as $\mathrm{Mr}$. Shaulis has, simply pulling out. Once the required bribes are paid and an investment is sealed, they complain, officials begin delaying, lengthening and altering procedures so much that turning a profit is often impossible. .

The cherubic Mr. Shaulis, the fruit exporter, arrived in 1994, long before all this happened. Flush with a stake of cash earned in grain ventures in Romania and Lithuania, he was drawn by talk of Uzbekistan's renowned fresh and dried fruit.

He lost $\$ 50,000$ almost immediately, as he tried to export grapes and cherries to Europe. It was a lesson in the first reality of business here that this region, landlocked and remote from Western markets, requires complex and costly transportation. In Mr. Shaulis's case, it took so long to organize a refrigerated truck that he lost his entire shipment.

In 1995, Mr. Shaulis, shifting from fresh fruit, won coveted Government permission to convert Uzbek currency into dollars - the first necessity of an import business. He began importing rice and tires into the hungry local market.

Then, in the fall, Mr. Shaulis jumped at another opportunity - a raisin processing factory bought by Soviet officials in 1989 and now idle.

Mr. Shaulis rented part of the plant, but when he arrived, he sensed a problem - a Soviet sort of prob-

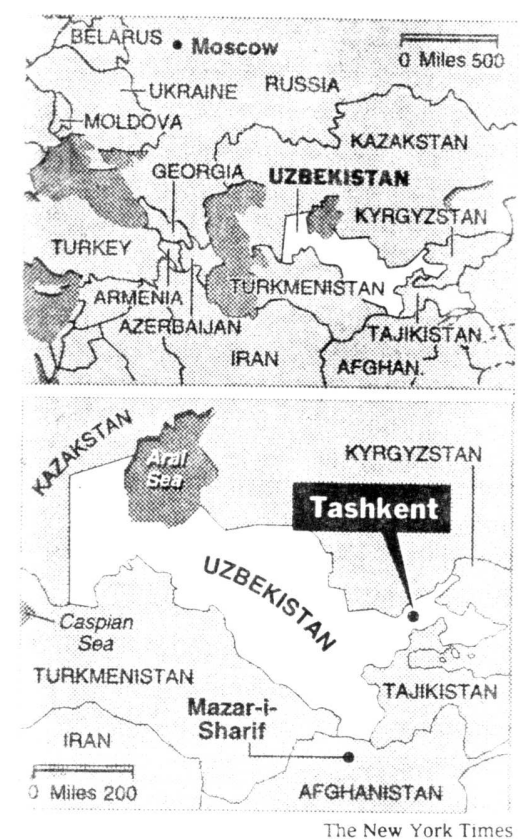

In Uzbekistan, a nation of 23 million, American dollars can easily be bought on the black market near the Kazakstan border.

lem. The work had to be delayed, the factory director said.

Why? Though he had been assured that the line was working, he was now told that the plant transformer was broken and that an engineer had it at home. On top of that, the home was locked, and the engineer was visiting relatives in Russia. It was not known when he would return. "They weren't being upfront with me," Mr. Shaulis says. "Did they come after me later to get my business? No, they don't do that here. I feel there must have been something wrong with the line.'

Finally came Mr. Karimov's halt to currency conversion. Mr. Shaulis, vith large debts to his tire and rice suppliers, now had no access to the tank deposits to repay it with.

Today, Mr. Shaulis is working off hs debt. Recently, he inspected an operating raisin-processing plant in the northern Afghan city of Mazar-iSharif and soon, he says, he will begin making shipments to Europe.

As for Uzbekistan, Mr. Shaulis refers bitterly to The Financial Times ad. "It's 100 percent opposite," he said. "They never honor their contracts."

THE NEW YORK TIMES 


\section{Kabul University seeks French aid}

KABUR: Fiat)ul University is looking for Frencin help in its hattle in shave culturad povery in Afghanistan, and fears by add workers that the latih

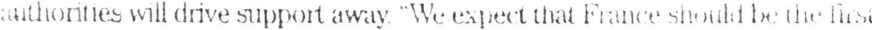

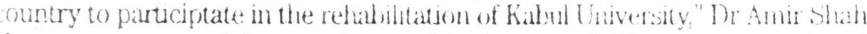

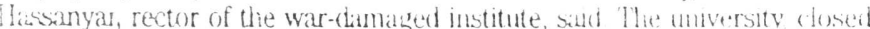

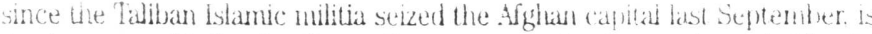

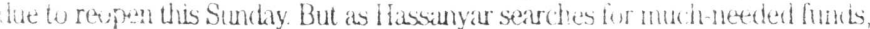
whd the Trench Change d'Affares in Afghanistan hats expresed willingless (i) assist, add wotkers in Kabul wan toreign assistane maly not be fonthom-

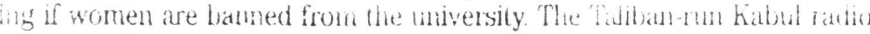
sidd recently ondy mate sindents should attend the university. Iniversity ath cials sud they have not recelved stath a directive but if a bat on ferrales is enti

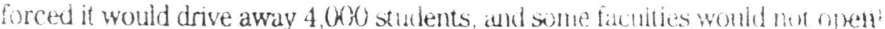
if the 60 wornen professors were itso barred. An?'

NATION (Pakistan)

\section{Troubles in Afghanistan's Capital}

- Mary MacMakin, a nurse and phvsiotherapist who has just come back from Kabul, Afghanistan, describes a divided city. One half, rocketed and burned, is being de-mined by United Nations experts. The other half is alive and intact, but under the control of a strict Islamic movement. Women caught without their faces covered are beaten with a rubber hose on their backs and legs, and sometimes their husbands get beaten. "not sadistically, but to punish," MacMakin said.

Hundreds of thousands of people have moved to a northern suburb of Kabul. The International Committee of the Red Cross and CARE distribute food, but U.N. relief agencies and Oxfam have suspended operations until a ban on women's activities is lifted, she added.

MacMakin said she helps find work for widows-a growing population that lives on begging, selling almonds or working as housemaids.$$
\text { THE W'ASHINGTON Post APRIL 25, } 1997
$$

"I ne news trom Kabui reads like a Monty Python script these days. Perhaps Maulawi Rafiullah's department should be renamed the Ministry of Silly Works," said Mr. Mohabbat, refer 'ring to an old British comedy show that featured a skit about a similar fictional ministry.

"The Taleban have closed public bathhouses, indispensable in

Ridicule offensive

The Afghan Embassy, which remains loyal to the ousted Rabbani government, is using ridicule to undermine the ruling Taleban faction in Kabul with edicts against men trimming their beards, women working or going to school, or people hanging their laundry out to dry.

"This embassy is working for President [Burhanuddin] Rabbani. We will never work a minute for the Taleban regime," said Mohammad Mohabbat, the charge d'affaires.

Declaring orders of the strictly Islamist Taleban to be "nonsense rules," Mr. Mohabbat referred last week to a recent crackdown on Afghan men who trim their beards. Sixty-five government employees have been fired for that offense, Reuters news agency reported, quoting Maulawi Rafiullah, director of the Taleban's Department for Promoting Value and Preventing Vice. poorer parts of town with no plumbing, and banned outdoor clotheslines to keep the sight of women's clothes drying from arousing young men," Mr. Mohabbat said.

The regime also has outlawed New Year's Eve celebrations, music, dancing, photographs and paper bags. The Taleban recently ordered Afghan residents to paint the windows on the upper floors of their homes so they cannot look into their neighbors' yards. Offenders have been beaten with whips.

The Taleban have been described as students, but Mr. Mohabbat dismissed them as nothing but rabble.

"Most are illiterate villagers who have never darkened a schoolhouse door. The 'clergy' who purport to lead them aren't much better," he said.

washington Times
THE ASSOClATED PRESS

KABUL, Afghanistan - Everyone must paint windows black so the women inside can't be seen. No white socks for females. No kite-flying, soccer or videos for anyone.

Once bombarded by deadly rockets, the 750,000 residents of the Afghan capital now are bombarded by Islamic edicts. And in the six months since the Taliban religious army marched into Kabul, many people have come to dread the nightly Radio Shariat broadcasts, fearing another decree.

"We have to listen in case there is something else we have to do," said Gul Jan, a Kabul resident.

The Taliban swept into the capital Sept. 27 , throwing out the sitting president and hanging a previous one. It has imposed its strict version of Islamic rule over the twothirds of Afghanistan it controls.

Women - the target of most of the Taliban's edicts - have been prohibited from working and going to school.

The Taliban say women have to be hidden lest they tempt men. One decree told people to paint their windows black so the worlen inside cannot be seen by nosey passers-bv.

When they do venture onto the streets, women must wear the all-enveloping burqa, which allows only a mesh opening over the eyes. White socks are also out, possibly because they might attract male attention.

Paper bags have been forbidden lest discarded pages of the Muslim holy book, the Koran, find their way into a recycling bin and become transformed - into a paper bag.

Flying kites is outlawed because it might interfere with prayers. Soccer is against Islam, according to the Taliban, as is music, photography and videos.

Many Islamic activists, even hard-liners, would scoff at such rules, particularly the edicts against women. In Iran, where an Islamic government came to power nearly 20 years ago, women have the right to vote, to work and to hold seats in Parliament.

Mainstream scholars have denounced the Taliban's decrees as backward and having little to do with religion. Islamic law which is based on the Koran and the traditions on what the Prophet Mohammed said or did - is interpreted by scholars whose opinions often diverge drastically.
But the Taliban rulers are serious about their new rules. They have set up a religious police force that roams the streets of Kabul in pickup trucks equipped with loudspeakers.

The bearded Taliban who ride in the back carry a stick in one hand and a Kalashnikov assault rifle in the other, ready to beat women they find breaking the rules.

In a single day last week, religious police beat six women for various transgressions - the worst being a woman who allowed her arm to be seen. For that offense, she was dragged from her vehicle and beaten publicly.

"This is essential so that other women will observe hijab (the full covering)," said Haji Kalahuddin, head of the Taliban religious police.

On another day, the religious police beat 24 shopkeepers and taxi drivers for dealing with women who were not wearing burqas.

Two French male aid workers were jailed for 26 days for mingling with Afghan women. They were released last week, but five Afghans charged with them are still in jail and will receive up to 29 lashes as punishment. 


\section{Taliban plans to restore TV broadcast in Kabul}

AABUL: Taliban militia is to restore clevision broadcasting to Kabul, but niy to show programmes which conform to Islamic principles, an oficial said Saturday.

"We will have television in the near future with feature films and programmes that are not violative of !slamic principles," said Mirza Mohamımad Yousafzai.

The announcement by Yousafzai, who heads an inspection and supervision board of the religious police - the department of promoting good and abstaining from evil - indicated a softening of the militia's rigid policy.

The Islamic militia, which conirols two thirds of Afghanistan. anned television broadcasts after capturing Kabul on September 27.

"The Taliban Islamic State is not against television, but it is against programmes contravening Islamic Shariat," law, he said.

"Ielevision exists throughout the world. We are not against modern inventions such as television," Yousafzai said.

The official said television in Afghanistan would show programmes depicting industrial development and other activities. "Dancing is the only thing not to be filmed," he added. The Islamic militia had banned music and barred women from working outside the home and ordered them to cover themselves from head to toe. Males were told to grow beards and to offer daily five prayers in mosques.

Yousafzai said a special announcement was issued Saturday to remind women of the restrictions once again.

IIis department. will cnsure that people do not engage in prohibited activities such as gaunbling, kite-flying, cock-fighting and dog-fighting even during coming Moslem Eid festival, Yousafzai said.

Afghans have pursued these traditional activities for fun and entertainment, especially on occasions such as Eid, to be celebrated here Sunday at the end of the Moslem fasting month.

Yousafzai said mobile patrols would keep a watch to prevent violations of the rules.

He said that the the upcoming Did woult be first to be observed in $\therefore$ fghanistan in accordance with the Istumic teachings:

\section{Penury-marred Eid for Kabulis}

KABUL - Thousands of people as usual packed Kabul's Feroshgah shopping centre on the eve of the Muslim festival of Eid ul Fitr, but this year poverty. and Taliban-imposed restrictions meant few were buying the traditional fare.

As veiled women and bearded men were Friday staring longingly at stalls laden with sweets and dried fruits the vendors complained that business had slumped almost 50 per cent.

Cookies, fruito and sweets are traditionally offered to guests during the Eid, the Muslim festivai celebrating the end of the month-long Ramadan fast.

But since the fundamentalist Taliban capturec the Afghan capital on September 27 prices have sky-rocketed, and most families preferred to spend what litule money they have on cheap clothes for their children.

A man handcuffed and with his face blackened was paraded through the crowd by Taliban soldiers who accused him of stealing a roll of cloth.

"Anybody caught stealing will be punished like me," the man was forced to shout by the Taliban.

The Taliban besices chopping the hands off thieves sometimes humiliate them by blackening their faces.

However, the display aroused little interest among the indifferent Kabul residents.

The Eid this year was "dis. tasteful because of poverty and restrictions," " one resident said. while stall owners complained of the sharp drop in business. $\quad "$

"Our sales have decreased drestically because 60 percent of the population ciannot even afford to feed themselves regularly leave alone buy presents for Eid," said Sher Agha, a grocery store owner.

A serior Supreme Court oflicial who dad not want to be iden. tified said he had come to buy essentials líke rice, sugar, oil and tea but he had no money. He was asking for the food on credit if somebody could trust him to repay later.

He said he had not been paid for months and his salary, when it was paid, was insufficient. His hopes of celebrating the Eid were dashed when the authorities again delayed paying his wacjes." Of course, Eid is to celebrate the end of the fasting month of Ramadan, but for me and for iny family fasting seems to be dragging on," the official lamented.

Mohammed Zia summed up the feelings of many Kabulis when he said the Eid held nothing for him this year.

"I have made no preparations, I made no new clothes for my childreii. I will not visit my relatives because if I see them my children will feel deprived," Zia said.

"Apart from its religious value, this Eid has no meaning for women. We feel caged," Arefa (Eds: one name) said.

"We cannot walk freely outside or put on colourful dresses because of the new restrictions."

The Eid may be a festival but there was little sign of a festive aur in Kabul.

The playing and selling: of Indian and Afghan music cassettes, once part of , the marketplace, colour of the Eid, have been replaced by cassettes of : religious hymns and musicless Pushtu language songs praising the Taliban. Although the fun has gone from the celebrations, residents said they do take some modicum of satisfaction knowing that lwo thirds of their cily is now out of rocket range.

The Taliban, continuing to fight forces of the ousted govern. ment under the command of Ahmed Shah Masood, are push. ing northwards from Kabul. Frontier Post 2/15 - (AFP)

Peshawar's Frontier Post has a Web page. Try http://www.pakcybe...post/nat13-25.html 


\section{Taliban Loses Ground in Eastern Afghanistan}

In heavy fighting in Afghanistan, the Taliban lost substantial ground in the eastern province of Kunar while they made some small advances just north of the capital, Kabul.

Meanwhile Afghan President Burhannudin Rabbani's military chief, Ahmed Shah Massoud, played a key role in mediating an end to a week-long hostage crisis involving combatants in Tajikistan's civil war. In other diplomatic news, Turkmenistan's President Saparmurat Niyazov traveled to Iran for two days of talks with Iranian leaders about Afghanistan and Central Asian affairs.

Forces loyal to Rabbani drove the Taliban out of eight districts in the eastern province of Kunar in February and have started to threaten Nangrahar province, whose capital Jalalabad is one of the country's most important cities after Kabul.

The Eastern Shura forces, which captured the Kunar territories, is a coalition of formerly neutral groups led by the ousted governor of Nangrahar province. The Shura forces said they captured "dozens of foreigners" fighting with the Taliban. While they did not specify the country from which the foreigners came, in the past numerous $\mathrm{Pa}$ kistani intelligence agents and mercenaries have been captured fighting with the Taliban.

Both Kunar and Nangrahar provinces border Pakistan and were the first provinces captured by the Taliban last September as they made their drive on Kabul. Their liberation would prove to be a major setback to the Taliban.

The election of a new Pakistani government also provides a new fac- tor which is sure to have an important effect on Afghanistan. It is still not clear whether or not the government of Pakistani Prime Minister Nawaz Sharif will maintain the same level of support to the Taliban as the previous government of Benazir Bhutto.

Pakistan's economic and strategic interests in Afghanistan are based on Afghanistan's position as the gateway to Central Asia. The Pakistani government has already signed a multibillion dollar deal with an American company to build gas and oil pipelines linking together Turkmenistan and Pakistan via Taliban-occupied areas of Afghanistan. The Afghan government opposed the fact that the deal was signed behind their backs and has accused Pakistan of supporting the Taliban with the aim of establishing a puppet regime in Kabul.

The central role played by Pakistan in Afghani affairs will ensure that observers closely watch Sharif in the upcoming weeks to ascertain what kind of policy he will pursue in the region.

The visit of Turkmenistan's President, Saparmurat Niyazov, to Iran may also have important implications for what happens in Afghanistan. Iran has strongly opposed the Taliban and accused them of serving American and British aims in the region. Iran has tried to drum up a regional coalition to demand an end to outside interference in Afghani affairs and bring about a peaceful solution to that country's civil war. Turkmenistan has been the only Central Asian state which has not expressed their strong disapproval of the Taliban.

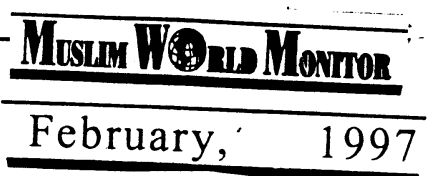

DIPLOMATIC DISPATCHES

\section{Stand by Your Women}

- Mehnaz Afkhami, executive director of the Washington-based Sisterhood Is Global Institute, said her organization was one of 60 human rights groups working to call attention to the plight of women in Afghanistan following the takeover of the country's capital last fall by the Taliban Islamic militia.

"For me, the Afghanistan situation was amazing," Afkhami said. "It was the first time women used e-mail on such a massive scale to network and to influence the foreign policy community. We are in touch with groups in Pakistan who are in contact with women in Afghanistan by telephone and other means."

When the Taliban captured Kabul, the State Department initially said it had no objections, cautiously awaiting developments should they prove to be the beginning of the resolution of Afghanistan's long-running conflict. But after reports of the Taliban's strictures on women's rights and education emerged soon afterward, the State Department voiced caution about the group.

The barrage of letters and messages, which influenced the government's reactions, was perhaps "the only salutary thing about this whole episode in Afghanistan," said Afkhami.

Reports that have filtered out of Afghanistan, where the Taliban barred women from going to their jobs and girls from going to school, are reminiscent of the early zeal of Iran's revolution, when militants reportedly cut off painted lips with razor blades and stuck thumbtacks into women's foreheads to affix their veils. One important consequence of not allowing women to work is the impact it has had on people's incomes and institutions that relied heavily on professional women, Afkhami said. Young boys must go to work while their once-employed mothers are forced to stay at home, and even boys' schools staffed by female teachers have had to close.

Afkhami said women are even denied treatment at Afghan hospitals if none of the female doctors exempted from the working ban is there. The Taliban have shut down public bathhouses, and many homes do not have electricity or running warm water.

An Iranian visitor to Washington said that in Iran women and young people also are faring worse than they ever have. Raids into private homes have been stepped up under the pretext of a crackdown on satellite dishes, and Iranian authorities have begun a purge of university professors. "In Iran, just to be yourself is to be political," said the visitor, who plans to go back.

\section{THE WASHINGTON POST}

JANCARY 10, 1997 


\section{Heavy Fighting on Two Afghan Fronts}

In late March, Afghanistan witnessed some of its heaviest fighting in months both north of Kabul and in the northwestern provinces of Badghis and Faryab. Meanwhile an ammunition blast in eastern Afghanistan killed up to 100 people in what is being described as perhaps the most serious accidental munitions explosion ever.

Despite the heavy fighting, there was almost no change in the front lines. The Taleban advance north of Kabul, which began with a midJanuary offensive, has been hindered by bitter winter weather and by unexpectedly stiff resistance from the Shi' ite Hezb al-Wahdat forces led by Abdul Karim Khalily. Earlier reports that villagers in areas controlled by Khalily had become so fed up with the despotism of their local commanders that they would welcome the Taleban, proved to be unfounded.

Khalily's forces are the weakest link in a three-way northern-based alliance opposed to the Taleban which also includes Abdul Rasheed Dostum's Uzbek militia and the forces allied to the ousted Afghan President Burhanuddin Rabbani and his military chief Ahmed Shah Massoud. A high level of distrust among the alliance partners has prevented them from integrating their forces, and thus in most of the fighting north of Kabul, the Hezb alWahdat is facing the Taleban alone. If the Taleban are able to break through Khalily's defenses in the Hindu Kush mountains, the route toward Dostum's stronghold of Mazar-i-Sharif would be open.

On March 17, the Taleban closed the Salang Highway, the country's only road linking Kabul to the north of Afghanistan. The road had largely stayed open during previous fighting thus allowing merchants to cross the front lines. An extended road closure would have detrimental effects on the economy of Talebancontrolled areas, but could have an even more serious effect on areas controlled by the northern-based groups.

Dostum has started heavily taxing locals under his control to fund the war effort as aid from Russia and Uzbekistan has slowed. In addition, inflation has soared and the value of the local currency plummeted as a result of Dostum's excessive printing of money to buy the loyalty of local commanders.

The economic collapse in Dostum's territory has seriously eroded his popularity, even among ethnic Uzbeks who had earlier seen Dostum as their protector against larger ethnic groups in the country. For the first time, many Uzbeks in Mazar-i-Sharif have begun openly talking of the possible benefits of a Taleban government which would presumably bring about a return of political and economic stability.

Taking advantage of this, the Taleban have repeated their offer of amnesty to opposition fighters in the hope that Dostum's support base will collapse. They have also stepped up an offensive in the northwestern provinces of Badghis and Faryab where the Taleban directly face Dostum. Despite extremely heavy fighting in those provinces since the beginning of March, the front lines have remained almost unchanged.

Meanwhile on March 19, the Taleban's security department headquarters in the eastern city of Jalalabad exploded killing an estimated 100 people, injuring at least 200 others, and sending debris and undetonated ordinance raining onto a residential area.

The security department housed as much as 400,000 pounds of explosives and the cause of the blast was believed to be accidental. There have been at least five previous incidents of exploding ammunition dumps in Taleban-controlled areas. A U.N. official said such explosions are common in Taleban camps because of carelessness in storing and handling ordinance

"There is no separation of ballistic weapons from explosive weapons, or of explosives from detona-

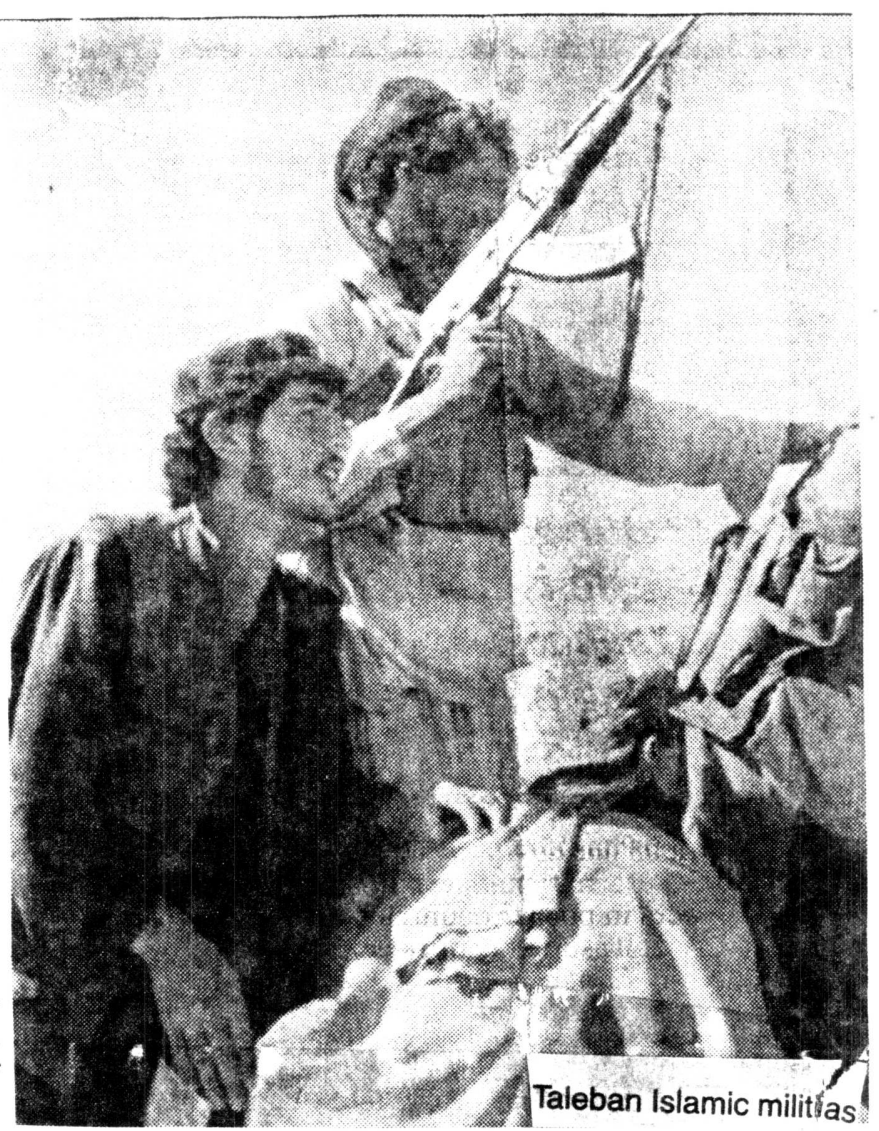

tors," the U.N. official said. "Unboxed, battle-ready ammunition is simply stored in heaps."

He said electrical interference could set off some types of weapons. Others might be detonated by percussion. There were no safeguards to prevent an uncontrollable series of explosions once the conflagration was under way, he added.

Another U.N. official described the blast as one of the biggest accidental explosions that has ever occurred and noted that it was made even more tragic by the Taleban practice of storing munitions in residential areas.

"This ranks as one of the biggest accidental munitions explosions ever," Ian Bullpint of the United Nations Office for the Coordination of Humanitarian Assistance to Afghanistan said. "Most explosions of this kind have occurred in military installations located some way from residential areas. The tragedy here is that so many civilians have been affected."

\section{MLsLM H\$}

March 28, 1997




\section{Taleban Forcibly \\ Evacuate Thousands From Shomali Valley}

Taleban soldiers forced tens of thousands of Afghan farmers to abandon their fields and relocate to the capital at a time when severe food shortages have caused the price of wheat to soar.

A fresh wave of refugees began arriving in Kabul after the Taleban swept through the countryside north of the capital forcing farmers in the region to abandon their fields.

Refugees said the Taleban beat people who refused to leave. Apparently the militia is afraid that villagers in the Shomali Valley are loyal to President Burhannudin Rabbani, who was ousted from the capital last September. The farmers in the region are ethnic Tajiks, like Rabbani, while the vast majority of the Taleban are ethnic Pushto.

Troops loyal to Rabbani had ambushed Taleban military camps a number of times in the days leading to the expulsions.

"The Taleban are afraid the people here support their enemies. That's why they force us to move at such a bad time." one refugee told international reporters.

In January, the Taleban began forcibly evacuating the residents of towns and villages flanking the-main highway leading north into the region controlled by forces loyal to Rabbani. In late March, the Taleban expanded the scope of the evacuations and, for the first time, started evacuating farmers as well as residents of more remote villages. By April 2, more than 140,000 people had been forced to flee Shomali, putting a major strain on Kabul.

The pressure has been intensified by a severe wheat shortage throughout Afghanistan, caused in large part by the lack of supplies from Pakistan. which is itself suffering from wheat shortages that led to riots in early April.

Pakistan. Which supplies Afghanistan with most of its wheat. banned exports and closed the border to Afghanistan on March 27 to prevent wheat smuggling. In the first week of April, food riots paralyzed parts of the North West Frontier Province and the Baluchistan province in Pakistan as demonstrators protested against the non-availability of bread for more than a week. Pakistan imports a substantial portion of its own wheat and blamed the late arrival of imported wheat for the shortages.

The wheat shortages have led to soaring prices in Afghanistan, where bread is a staple item in the diet.

"Bread is now out of the reach of the most destitute families. With the influx of over 140.000 internally displaced people, a shortage in supply has been exacerbated by an increase in demand," said Terry Pitzner of the United Nations refugee agency. "I urge the Afghan authorities to take immediate action to resolve this shortage of wheat flour."

The Shomali Valley, from which the newest wave of refugees have been expelled, is an important source of food for Kabul and April is usually the spring planting season. Another spokesperson for the UN refugee agency said that the current displacements from the area would have a long-term negative impact on the whole country.

"At this time of the year, the population should be planting their crops and pruning their fruit trees, not themselves struggling for food," Pam O'Toole said.

In addition to the 140,000 people forcibly removed from the Shomali Valley, another 40,000 have been displaced by recent fighting in the northwestern province of Badghis, where fighting has been especially heavy in late March and early April.

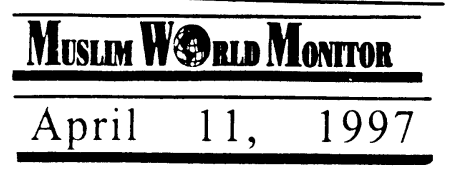

OUSTED AFGHAN PRESIDENT SETS UP NEN CAPITAL AT TALOQAN (From AFP - 4/26)

Taloqan, the capital of Takhar Prov., is now the de facto capital of Rabbani's exiled gov't. It houses some 3,000 Eamilies who fled the Taliban occupation of Kabul, 3 NGOS \& consulates of Iran $\dot{\alpha}$ Tajikistan. Schools are open for both boys \& girls although classes are segregated. In Kabul, Taliban forced women to wear a full-body veil; in Taloqan the same aress code applies but it is tradition, not an imposition. "It's a conservative town, but not fundamentalistic," said a foreign aid worker. "It's a place of fun," says a man who squints at a small tv screen showing a Hindi movie. In a teashop, customers lounge on carpets as they are entertained by popular songs cranked out at top volume from a Japanese cassette player. "If romance is a sin in the eyes of God Almighty, then I am guilty from head to toe," says one of the men. Alcohol \& drugs are banned in both Talogan \& Kabul, but both have a black market in hashish as the cannabis plant is widely cultivated in Afghanistan. Kabul under Rabbani was rife with corruption \& banditry on the highways was not uncommon. But in Taloqan the Rabbani faction has made a concerted effort to improve discipline. Citizens are not allowed to carry guns. "Security is good in Taloqan but not as perfect as Kabul," said one exiled intellectual noting the Taliban's clean record.

(story by Terence White)

\section{Ossama to finance Afghan infrastructure projects}

\section{AFP}

CAIRO: A former Saudi citizen who bankrolls Muslim militants will fund infrastructure projects in Taliban-controlled sectors of southerm Afghanistan. the Arab newspaper AiHayat said Thursday.

Billionaure Ossama bin Laden agreed "during a meeting with the head of the Taliban. mullah Mohamed Omar in Kandahar to take on inirastructure projects in the south of the country," the London-based paper said. Al-Hayat said the projects he ggreed to fund include "development of the road linking Kandahrar to Jalalabad and digging a canai to divert the water of a river to reclaim desert areas near Kandahar."

A spokesman for the Taliban miiitia which seized Kabul last year. admitted Wednesday for the first time that bin Ladien was living there under the group's protection.

- We will not put pressure on him to leave Afghanistan." Ilullah Amir Shah Muttaqi, acting Taliban Minister of Cuiture and Information. toid jour. nalists. 


\section{From. UNARMED WARRIORS}

\section{III-A GOOD WAR}

$\mathrm{T}$ E International Committee of the Red Cross is proud of its program in Afghanistan, and it has reason to be: it ieeds a large number of people, has rebuilt the shattered limbs of mine victims, visits prisoners on all sides of the conflict, and has taught the mujahideen, versed in the pitiless logic of jihad, the laws of war. But how do vou judge a program a success in a country where a million people have lied since 1979?

In late September of last vear, the I.C.R.C. invited me to visit its field operation there. A week before I was due to arrive, I got a call from Geneva telling me that Taliban militias had broken through we government lines southeast of Kabul. that the United Nations and some aid reencies were evacuating nonessential versonnel from the citv, and that the I.C.R.C., as usual, would in large part remain. Did I still want to go?

By the time I arrived in Peshawar, Kabul-had fallen. I hitched a ride on the sec(nd relief flight into the city. Mountains that had been burned brown ringed the airport, which had been built by the Soviets and was now scarcely functioning: its windows were blown out, its baggage hall was darkened, and the convevor belts were still and were covered in dust. Squatting at the edge of the runwav was a cluster of Taliban fighters - turbaned, baggy-trousered, leaning on Kalashnikovs. Behind them was a Mitsubishi Pajero with rocket-propelled grenade launchers.

Talib means "religious student," and the movement began in the Islamic seminaries in Pakistan in the early nineteen-nineties. By 1994, the Taliban militias, armed and trained by the Pakistanis, had begun their march to claim Afghanistan while enforcing the strictest version of Islamic law ever encountered in the Muslim world: prohibiting women from employment; forcing them to wear the burka, with its hateful lattice grille over the face; stoning adulterers; and amputating the hands of thieves. Now the Taliban controlled the capital and three-quarters of the country.

In the landscape of endemic war, $\mathrm{Ka}$ bul is in a class of desolation all its own. It is the Dresden of post-Cold War conflict: mile upon mile of rubble and dust, abandoned and windswept, populated here and there by ragged families eking wut their survival inside abandoned truck containers that have been sawed in halt. Ranging up the hillsides were thousands of rootless and windowless houses, deserted by their former inhabitants. The warring militias had spared nothing: the blue-domed mosques, the minarets, the hospitals, the schools. The Kabul museum, which once housed a collection of carly Buddhist relics, lav open to the skv, its ancient columns lying about on the roadside, its collection looted. The Soviet Embassy and the Soviet cultural center had been ripped apart, and Taliban artillery detachments were scuttling about in the ruins.

In 1992, when the Soviet-backed regime of Muhammad Najibullah crumbled after an army mutiny, he and his brother had sought refuge in a U.N. zuesthouse in Kabul, and Najibullah staved there for four vears. Three nights before I arrived. the Taliban had dragged him out of the guesthouse, castrated him and beaten him to death, and hanged his pulpy body from the stanchion of a traffic warden's observation tower. As I drove into the city, only the noose, flecked with blood, remained swinging from the tower.

The I.C.R.C. headquarters, in the center of Kabul, was hidden behind piles of sandbags. Its lintels were reinforced with rough-hewn timber supports. A dozen white Land Cruisers were parked in the yard, each with a Comite Internationale Geneve decal on its doors and the sign of a Kalashnikov with two red slashes through it: no weapons allowed in I.C.R.C. cars, no weapons in the compound. Unarmed local employees frisked everyone who came through the gates.

\section{THE FAILURE OF SAFE HAVENS}

In the davs since the Taliban takeover, I learned, the I.C.R.C. had been opening up lines of communication to the rebel commanders who were running the city. "Running the city" is a euphemism. Actually, Kabul was without a government. The Tauiban leaders had commandeered every available vehicle and rushed north to chase government forces farther into the mountains. The detachments left behind to administer the city were not doing a lot of administering. Many of the prisons had been emptied, and the Red Cross compound was filling up with former prisoners bearing yellow I.C.R.C. registration cards and seeking relief. The hallways, especially those adiacent to the satellite phone, were crowded with iournalists, avid to cover the Taliban take()ver, though Kabul, from their point of rew, was distressingly tree of televisable igns of recent carnage. Struggling to cope with them was an I.C.R.C. press delegate, a former journalist with South African radio who was now enlisted in the "cause," as he called it, half ironically.

The Afghanistan delegation head was Michel Ducraux. His office had reproductions of Vermeers and Matisses, shatterproot plastic windows, and a view entirely blocked by sandbags piled eight teet high. Ducraux is a lean, elegant man in his early fities. He appeared coolly reflective and seemed to keep cynicism and commitment in a subtle inner equilibrium. His view of the war enjoved its paradoxes. The entire delegation, he recalled, had recently spent the dav in shelters below the compound as Muslim militias rocketed the city: a curious position for the delegates to find themselves inendangered, huddled for hours in a dark, cramped shelter while providing medical assistance to factions industriously committed to murder, trying to teach the laws of war to militias bent on destroving each other, and preaching restraint to Islamic warriors who among them have reduced their own city to rubble. It was "byperdésagréable," Ducraux said.

The Afghans are border people, on the spiny buffer between civilizations-Iran, India, Central Asia- and have fought evervone from Alexander to the British Army to keep a stubborn independence alive. They have a reputation as being among the most redoubtable guerrillas of all time. Their tradition of fightingbased on small, mobile units that avoid direct attack or pitched battle, seeking instead to use the mountain passes to ambush the enemy and surround it-was what brought them victory against the Russians. It was a tradition that respected the ecology of a poor society and the climate of a mountainous one: war began once the crop was planted or the animals were put up in the pastures, and it stopped when the harrest came and the snows descended. War was endemic, but it was self-limiting.

Once the warlords had ceased to be united against an external enemy, however, they began turning against each other. The radicalization of Islam made things worse: instead of bringing the miltias tocether. religious principle now set 
them at gunpoint. And the weapons left behind by the Russians, and those shipned in from the Americans-from tanks to Stinger missiles-were so powerful that they overwhelmed the self-limiting ecoiogy of warrior traditions. Afghan warriors of the past did not target mosques and minarets, hospitals and schools. Kabul is the gravevard of the Afghan warriors honor.

So what was the the I.C.R.C. Hoing here now? Ducraux was characteristically philosophical. "What is more human than war?" he mused. The organization was not here to stop war, or even to humanize it, he said, and he went on, "We're here to reduce the damage. To feed the widows, to visit the prisoners, to fit new limbs on the bodies of those torn apart by mines." Var was absurd but inevitable: What else was there, the International Committee of the Red Cross seemed to be saving, but the modest morality of small deeds?

I was not easy to meet the Taliban fighters. Most were in the Pansheer Valley, to the northeast of Kabul, and those left behind to guard the city were hostile to foreigners. But there was a detachment in residence at the Intercontinental Hotel, an improbable wedge of sixties bruwlicm miraculoucly still perched on ton of one of Kabul's hills, with a panoramic rew of the devastation. Tanks and artillery were deplened in the pine groves around the hotel car park. With an IC'R.C. interpreter the had prudently dotfed hic Wectern iacket and donned ? small white can this stuhble had been arowing for several tarel-I approached 3 detachment of Talihan sitting on the grace hy the drained hotel pool and looking out over the dustr haze of Kabul. They were sitting cross-legged, their hearded faces framed hy their turbans, and were languilly dismembering roses from the hotel gardens or turning over worry heads in their fingers. They had new watches and new shoes.

I acked what they were fighting for. and they turned to the one who was apparently the most colucated of them-a feece volng semimarian with a Wectern havirut and a long heard. "For Islam," he said. "To stop the fighting among the benthers. And to have an Islamic state."

But then, I acked, why are the bonthcresill killing one another?

Whe are the hrothere fighting? The H'e ther Nuhammat. mas his name he hesced, instructed us that when corruption is on the earth one must fight to ving peace."
The next morning, the Taliban identified an example of corruption-in the very cellars of the Intercontinental. Fourteen hundred cans of heer and eirhteen hundred hottles of "alcoholic drinks" were dragged out and piled up in the car park. After pravers and a short speech by the head of the Taliban religrious police (a force whose name means "the Department of ( ommand of Gond and Iniumetion of the (nnlawful"), the bottles were ceremonially smashed and the cans crushed, while an invited audience of parched Western iournalists looked on in undisguised dismav.

When I returned from the Intereontinental to the I.C.R.C. compound, I found that furniture was heing moved into the courtyard. Turbaned Afghans were struggling past, carrying chairs and tables. Two women delegates -an office administrator and a nurse- had put on head scarves and Afghan trousers. The Aferhan womenwho run the mescage ststem, maintain files on prisoner-of-war visits, and trace prisoners and missing persons-were heing moved out of sight into a separate hlock, behind a wall of sandbags. In other words, the Red Cross was reorganizing its offices to keep the women hidden and the Taliban happy.

Thomas Gurtner, the deputy head of the I.C.R.C. in Kabul, had just returned from a meeting with other relief agencies-Oxfam, Médecins Sans Frontières, UNICEF, and the United Nations High Commission on Refugees. All ran programs that employed Afghan women. All were protesting against the Taliban decrees that suspended women from their jobs, forcing them to return to their homes and to the dominion of their husbands and fathers. These agencies had been calling upon the I.C.R.C. to join their appeal. Gurtner had refused.

"Is it a humanitarian issue with you?" I asked him.

"Of course not," he replied briskly.

I was beginning to understand that the laws of war are one thing and human rights quite another. The I.C.R.C. enforces the laws of war; it has nothing to do with human rights. It does not campaign against injustice. Its legitimacy depends on its working with warriors and warlords: if they insist that women be kept out of sight, it has no choice but to go along.

$\mathrm{H}$ ov: do you teach the warrior's code of honor to men trained in Islamic Iithad? Inw do you teach the laws of war to people who may never have heard of the Geneva Conventions?

The I.C.R.C. delegate in charge of "dissemination" in Kabul was lean-Pascal Moret. At forty-two, Jampa-his radio call sign-is older than most Red Cross field workers. Ite has no university degtee. sometimes drives a taxi in Geneva hetween his Red Cross missions, and is a practicing Tihetan Buddhist.

As Iampa observed, everything that the Red Cross does is dissemination: if you drive yout Land Cruiser too fast in the strects of Kabul, wou give the whole delegation a reputation for arrogance: if voul talk back to a Taliban at a checkpoint, the next I and Cruiser that goes through mav get fired upon. Dissemination, in other words, means preserving the moral currency ot the Red Cross symbol. If the Afghan program is a "success," that is largely hecause the stmbol still retains legitimacy among all the factions. The I.C.R.C. cant stop the flow of arms from Pakistan and Russia; it cant force a ceasefire or a trice.

\section{THE JIHAD TRADITION}

It can only try to get the factions to observe some basic rules: don't shoot the wounded; don't fire on ambulances; don't target hospitals; don't attack civilians; don't torture prisoners.

A generation ago, the I.C.R.C. made few concessions to local culture. Before I set out for Kabul, one veteran, Pierre Gassmann - who is now the head of the I.C.R.C. delegation in Colombia-told me that dissemination had changed radically since he joined the organization, in the late sixties. "First, we threw our book at them," he said. "Then we threw theirs. Now we don't know what book to throw at them. We're trying something a little more subtle."

In Somalia, the Red Cross runs theatre groups that perform both for the various clans and for groups of gunmen; the delegation has hired singers and poets to record songs about-believe it or notthe laws of war, and the songs and dramas are plaved on the BBC World Service. In Chechnya, first-aid teams distribute a shoulder bandage printed with cartoons showing warriors lifting the wounded from the battlefield, escorting orphans to safety, and rounding up prisoners and taking them into safe custody. But the biggest challenge is how to teach the European rules of war to radical Islam.

In medieval Europe, there was a distinction between bellum bostil 
(warfare characterized by restraint) and bellum romanum (warfare, in the words of the historian Michael Howard, "in which no holds were barred and all those designated as enemy, whether bearing arms or not, would be indiscriminately slaughtered”). Medieval Christendom carried this distinction into the Crusades against Islam: unmitigated ferocitv reserved for unbelievers. Islam responded in kind; jihad was its very own bellum romanum. The moral particularism of these traditions, which distinguish between worthy and unworthy victims, stands in contrast to the

moral universalism of the Geneva Conventions, which call on soldiers to respect all victims.

There is something attractive herea determination to prove that the Red Cross's principles are not merely products of Swiss Calvinism but human universals, which can be found in all cultures. Equally, there is something poignant in the Red Cross's curious faith that human violence can be contained by injunctions from holy books. The Kabul office has printed similar injunctions in its calendars. These calendars, with their humanist messages, have been hanging in buildings surrounded by devastation.

Afghanistan, however, poses an additional problem. War is alwavs at its most unrestrained when religion vests it with holy purpose, and the Taliban is perhaps the most militantly religious militia on earth. At checkpoints around the city, its fighters were searching cars for magazines and cassettes. I saw videotapes and audiotapes festooning a tree near one such checkpoint, and assumed they were pornographic, or rock and roll, or some kind of anti-Taliban propaganda. But I learned that the ohicetive of the fiehters is in met much wider. Thev are searching for mothing that depicts the human face or me of ( ind's creatures. In no other Islamie asciets have the new resolutionary anthuritios gone so far. The imams of

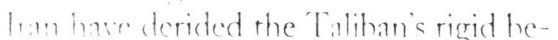
tont in the pernicions effect of vianal ren

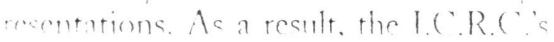

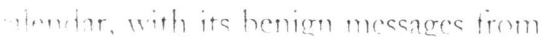

Istamic texts, will be kept ont of sight. So will the comic hook that the I.C.R.C. has dictributed tocalls, in compuncton with as BBRE metro drama on the life and hard times of Ali (iul, a fictitions Afrhan heros. th the talihan leaders hase their wav, all this patient and rather suhte work ot tmatating the Furopean lawes of war inte the remacular of local warroter colture will he pulped. The eres are the windows ot the sent Ind aceording to the Talibands are strict interpretation of the Koran, all Enetions of the eve-all photongraphs. mantinese, prints, videos, and films-are

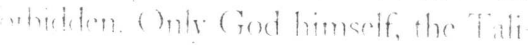
mon leadere say, should cee into the wh Huse of the anul.

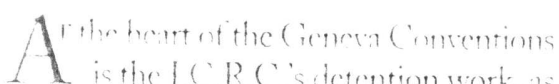

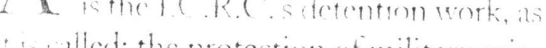
- med: the protection of military pris metsent war. The delegate in thatgen wis whe the hatul prisoners is Pascal Mancinle, wentier ane of the new hreed that seems

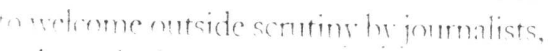
pertare the hetter to cosint them. He in ited me to join him on a detention vicit

He had divided his team into three empes two of them went to a prison reentip diseneered to be holding militia men from the government cide who had been taken be the Talihan dumber the capture of Kabul: the third went out into the its to investiente stories of summary ar use suppocedly carried ont hy the Tali un centrits foreces. I was assigned to one it the prison details.

The preon was a decrepit wellowe struc twe with a straw roof and heasy stone walls Taliman guards, backed up hy a tew Pakistani secret-service police, were lounging at the entrance to the long, dark ceil Wreke. The how cell doors were flimse conamictions made of wood, and the lexks were perfinctors. IVe ducked low and entered a cell. approximately cir fect by ten feet, that helit entheen prisoners sciutting on dirt mattereses. A few plastic hases of hehengringe hung from nails on the walls.

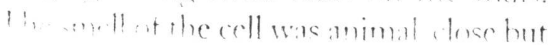
doan. Through broken panes in a window you could hear car horns and hawkers cries coming from Chicken Strect.

The prisoners, who crowded around us, were disturbingly young: few, I soon learned, were older than eighteen, and several were not more than fourteen. Some harcly had their first growth of beard. As an I.C.R.C. delegate, sitting crose-lecged on the floor, began registering them, filling out a card of personal detaik for each prisoner, their stories came un in hits and pieces. Ther were montly cthnic Taijks. None of them admitted to hemer remilar soldiers. Thev ail clamed to have heen working as peddlers, waters, of garage mechanics, and to have heen sucked inte the militias because, in a collansing economs, the militia on the government cide offered them securits, mones, and ford. But the hadn't proved to be very derermined fiehters. Having heen posted to the southeastern outskirts of the city tor re pel the Talitan advance, they had surren dered-en ther sad-without firing a shot

As the delegate took dowi one prisoners details, I folded the vellow recristat tion card of the preceding prisoner, slid it into a plastic folder, and handed it to him. Many received their cards with a little bow or with the Afghan gecture of place ing a hand briefly over the heart. Then each slipped his card into the inside pocket of his hown wastenat. There was something sommental ahout this rimal. In jails, lectupe, ages, and camps around the world, prisoners like these have heen getting cards like these, their grarantee of such protection and moral concern as the Cenewa (omentions can offer them. It is pront that ther have not heen forgotten, that some foreigner will make it his business to demand information if ther go missing or show up at his next visit with bruises on their bodies.

But the vellow cards do not seem to the nearly enough. () nce everyone was registered and had his card, the prisoners seemed to press forward. One spoke urenently to the delegate for a long time. When the were taken ty the Talihan, thev were promised amnesty. They wanted the Red Crosedelegate to take up their cause.

The delegate gathered his papers. Ite was perempton: Amnestr was none of his affair. The I.C.R.C. wasn th the huciness of intervening in the "process of justice." The (ieneva ('onventions are not athout justice hut atrut gend treatment. The I.C.R.C. was there to make sure that the men were decently treated and fed and that when ther were released they would get some assistance to get back to their villages. Dark lonks were exchanged, and there was a lot a clicking of tongues as we howed and made our way out through the cell door.

$\mathrm{T}$ IROT ringerT my time in Kabul, people told me I had to meet Alberto. Like all local legends, he did not seem to have a second name-just Alherto. He wasn texactly atypical I.C.R.C. delegate, but he did seem to symbolize for many reporters what was admirable about the organization. Herte turned out to be 
Ilberto Cairo, a tall, thin, and intense talian in his mid-fortics with round wireimmed glasses, graving hair, and an air excited distraction. He had heen in Whul for seven vears-ionger than any ther delegate and loner than aimoct any ther cxnatrate in the city. He was there hen rockets landed on Kar Teh Seh hosral, and the combitors filled with the rounded and the dwing; and when the cruge for the blind was damaged by tosion: and when the murahideen ternorred the Marastoon shelter for the men ally ill: and when cholera troke out: and nen a Red Cross murse was killed snuth est of the citr; and when Red Cross am wances were targeted. He had come as physiotherapist and now man the C.R.C.s biggest uresthetic-limb weram anywhere: the orthonedic center - Wazir Akhar Khan hospital. It was a ariving workshon, statfed largely by if man war-wounded themselves. He took ve on a tour, kissing an amnutee who was rimming new limbe on a lathe; nuthing the hair of another, who was shaping plaster around the stumps of recent amputees; and mock-punching the arm of a third, who was firing new casts in ovens. The heels on the artificial limins, I learned, are cut from old Soviet tires. "The quality is excellent," Nherto said.

Many of Alherto's patients were voung Aghans who, never having been to school. entered the militias hecause the wariords were the only people who paid a wage. Now they stumped un and down the gar-

on paths outside, heaving their strange

new limbs across the eravel. Besides the

rrine, there were other. even grimmer casualties of war. In one room, a small bundie of gray-blue rage lay on a hospital cot. Wherto pulled aside its enver and revealed a dusty-faced child of ahout seven shivering in her siecp. "Polin," he said. Immumization programs had faltered, and, with the war. polin had returned to Afghanictan.

Wherto wanted me to meet his chief atministrator. Noheh Ali, a twenty-sixear-old paraplecric in a wheclchair, who ac wearing sky-hlue painmas. Tivo years

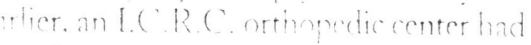
wond itedf mught in the erosefire be acen the erowermment gumsan Television Hill and an Istamic militia holed up in a ancen of streets ncathy The expatriate at whithew, hut Mohet whanteered to mand in the center, with a radier and a few mets an do what he sombte protect the and limb-mbing mathiners in case momomend chould the ctomed. The

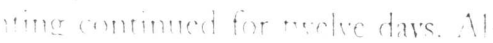

erto, with the delegation in the middle

it town, contid communicate with Moleh

why hadio, and at times the gumfire was

lomit that he could harely make out

the Wheh was saving. Then, one night,

meroment foreses fought their wav into

mponnd and seized Moheh and his

mars thinking that thes helonged to the milin ther had heen fighting, "I was say-

me pravere." Moheh douty recalled.

theren, iesperate, persuaded a gow-

monent minster to onder his troops to

Which alone. The next night, the militin took the orthopedice enter. Help his whectehair in the hunker

Whet heard them commer therough the mmonumd gate. "I hegan to pray again and and the Holy Koran," he sald. This time, government artillery drove the militia out of the compound

Two weeks later, Atherto finally got both factions to agree to let an I.C.R.C. convor evacuate Moheh and his guards. The fond had all hut run out, and the bat teries in Moheb's radio were almost dead. Mohet was ready. Ile and the guards had managed, amid continuous rocket fire, to prepare most of the machinery for evacuation. Almost single-handed, Moheb had saved the center.

For me, this was the story of $A$ fghanistan, where two sides, so maddened by weapons and ideology, would not scruple to kill each nther over nossession of a Red Cross orthopedic center. For Alherto, the story explains why he has remained in Kabul. When Moheb had finished his tale, Alberto looked at me with an exnressive Italian shrug and said, "How can I leave?" What Moheb thinks his story means took a minute or two to discover. He turned back to his laptop computer and his purchasing orders and then said something so softly I had to ask him to repeat it: "The Red Cross made me hrave."

THE NEW YORKER, MARCH 24, 1997

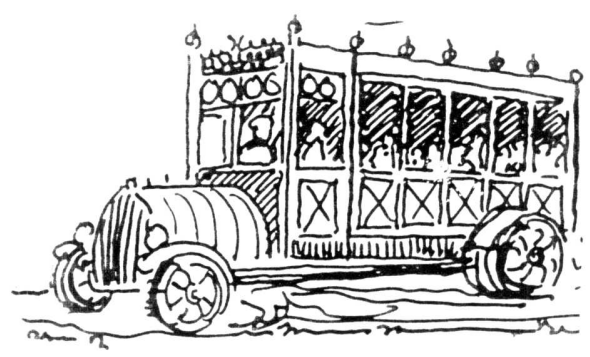

\section{MLsLim W9 Rid Montor}

Since the election of a new cov ernment in Pakistan, the Talcban have found themselves increasingly isolated. Before taking Kabul. the movement enjoyed the strong support of Pakistan as well as the Lnited States, which has also backed off from openly supporting the movement after it passed a series of decrees, the most notable of which hanned women from working or going to school. Despite the fact that they control over $75 \%$ of $\mathrm{Al}$ ghanistan, including Kabul, nocountry or international body recognizes their government as legitmate. The United Nations continues to recognize the government of President Burhannudin Rabbani as the official representative of Afghanistan.

Also, the December 23 ceasetire accord signed between the Russianbacked government of Tajikistan and its Islamist opponents threatens to further isolate the Taleban. The accord was signed after negotiations in northern Afghanistan which were mediated by Rabbani and his military chief Ahmad Shah Massoud. both of whom are ethnic Tajiks.

The ceasefire has held for nearly three months and on March 8 a new agreement was signed which sets out a four-step plan to integrate the armed Islamist opposition into the regular Tajik armed forces. Such an integration may enable both sides put an end to the growth of rogue bands which have taken over local territories and set up lucrative drugrunning enterprises. A new round of talks on a political protocol is to begin on April 9 in Tehran. Iran. Both Tajik opposition and government forces have expressed their optimism that a complete and comprehensive peace settlement can soon be reached.

The Taleban fear that a united Tajikistan will provide support to Rabbani's forces. in early March, the Taleban accused the Tajik government of having already allowed its territory to be used to help resupply the forces of Ahmad Shah Massoud and threatened "dramatic consequences" if such support continues.

March 14, 1997




\section{Fohans Caltinate Stamic State but Ignore Illicit Harvest}

y Kenneth J. Cooper

ashington Post Foreign Service

CANDAHAR, Afghanistan-Afer the Taliban militia took control if Afghanistan's capital last Sepember, its leaders vowed to estabish the most Islamic state in the vorid. Two months later, in the jlanting season in southern Afmanistan's opium poppy fields, the undamentalist militia denounced the llowering crop used to produce ieroin as un-Islamic.

But at the start of harvest time lere in the Taliban's southern tronghoid. mature fields of white, ink and red poppies are in bloom. They spiash color even inside the var-damaged city of Kandahar, the nuitia's headquarters, where one mall plot flourisnes across a dirt caad from the mud-walled central aii.

In the course of their nearly three-year-old fight to rule Afghanistan, the Taliban's leaders have cracked down-sometimes violently - n the people living in the twothirds of the country that has come under their control. The Muslim clerics and their followers have punished harshly women in dress deemed immodest, men with cleanshaven chins, adulterers, thieves and sports players.

3ut they have shown no such resolve with producers of raw materiai for intoxicants clearly forbidden in the Koran, Islam's holy book.

"There are no signs they have been doing anything," said Angus Geddes, a U.N. official working to persuade Afghans to grow other crops.

According to the State Department and the United Nations, Afghanistan harvests at least 30 percent of the world's opium poppies. By the State Department's reckoning, that makes Afghanistan the worid's second-largest producer of opium poppies. The U.N. Drug Control Program, using different survey methods, estimates that Afghanistan's output now rivais Burma's as the largest.

More than 90 percent of Afghanistan's poppy-growing areas are under Taliban control. country s biggest poppyproducing province, Heimand, borders Kandahar Province to the east. Yet despite the Taliban's professed religious convictions, it has not acted with customary zeal to stop poppy cuitivation. Its reluctance stems from the damage Afghanistan's economy has suffered during nearly two decades of war, the revenue derived from a 10 percent tax coilected on opium and a fear of losing popular support from hundreds of thousands of smail growers of poppies.

Everyone is growing poppy. If we try to stop this immediately, the people will be against us." said Abdui Rashid. drug control director for Kandahar Province.

come Taliban leaders have suggested to U.N. officiais that they would be more inclined to enforce international anti-drug agreements and ban poppy cultivation if the United Nations and Western nations recognized their fundamentalist regime, which no government has done. The hints amount to a kind of narco-diplomacy-seeking international legitimacy while condoning trafficking in illegal drugs.

"T've heard that argument: Once we get recognition, then we will deliver all the good things," said Norbert Holl, a U.N. mediator assigned to negotiate an end to the ongoing civil war between the Taliban and an alliance of northern militias, including the former government of president Burhanuddin Rabbani that the Taliban drove from Kabul last year.

Rashid said the civil war was partly responsible for the continuing poppy cultivation. "When we take control of the entire country, we will stop it. In these days, we're too busy with the fighting," he said.

Rather than destroy easily identifiable poppy fields and risk popular wrath, Rashid said, the Taliban has adopted the more difficult strategy of intercepting drug shipments along Afghanistan's 1,500mile border with Pakistan and 580mile border with Iran. The border between Afghanistan and Pakistan is particularly porous, with many

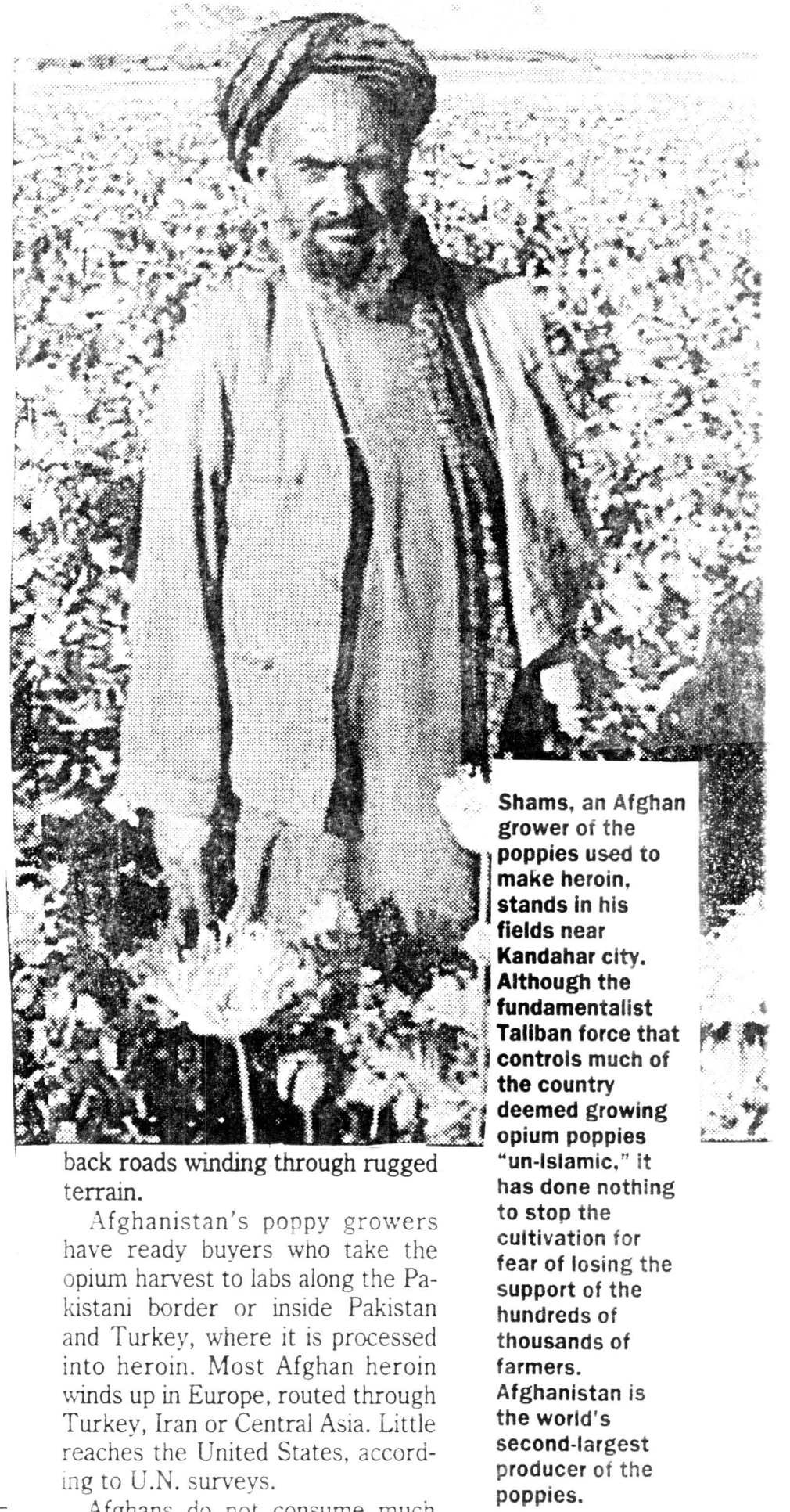


opium or heroin; though hospital personnel in Kandahar said they occasionally discover surgical patients are addicts because they need massive doses of anesthesia. The Taliban has enforced a ban on hashish, a milder drug used by soldiers on both sides of the civil war.

For Afghan farmers, planting opium poppy on at least part of their land represents a sensible choice in one of the world's poorest countries, where small farming and undisguised smuggling appear to be the major economic activities. Opium poppy pays more and requires less water than other crops. It also reaps cash advances from buyers to pay for fertilizer and seeds.

"That is the reason we are growing this-to make more money," explained Issa Khan as he shoveled mud to redirect the flow of irrigation water to his blooming poppy fields. "Nobody has asked us to stop this."

Farmers have grown poppy alongside wheat, fruit trees and spices as insurance against the failure of other crops that need more water, which is scarce in many areas. Because he earns twice as much from poppy as he does from wheat, Khan said he planted five acres of poppy and four acres of wheat during the winter growing season that is coming to an end. Wheat is the basic ingredient of a flat, unleavened bread that is an Afghan staple.

Before the Soviet invasion in 1979 , the farmland seven miles west of Kandahar city that Khan and other poppy growers work was covered with grape vineyards. Local farmers said they blame the Russians for the vineyards' destruction during the decade-long war against the former Soviet army.

Ahmed Gul, another poppy grower from the area, picked up a rusty mortar shell from a poppy field, walked over to foreign journalists nearby and declared: "We are cultivating this because the Russians used this weapon. Now, we are cultivating and exporting this as an atom bomb."

Helmand Province, which produces about 60 percent of the poppy crop, was the country's breadbasket until an extensive irrigation system built with U.S. aid fell into disrepair-like most of Afghanistan's infrastructure-during two decades of warfare. "There was all this wheat and all this cotton, and now it's all this poppy," William Bergquist, a U.N. official based in Kandahar, said.

Geddes said the United Nations has tried to persuade poppy growers they can make as much money from fruit orchards, onions and other vegetables. Under another U.N. program, local leaders will be asked to ban poppy cultivation in their areas in exchange for a development project of their choice.

Both the State Department and the United Nations have reported that the Taliban collects a 10 percent tax on opium poppy.

Rashid denied the militia taxes poppy growers, but said local Muslim clerics might receive the tithe. One Afghanistan specialist doubted the poppy tax is a major revenue source for the Taliban, which has received the bulk of its war resources from other Islamic funda-

\section{"Everyone is growing poppy. If we try to stop this immediately, the people will be against us."}

$$
\text { provincial drug control director }
$$

mentalists in Saudi Arabia, the United Arab Emirates and Bahrain.

In three verses, the Koran warns Muslims against involvement with alcohol or drugs. The strongest language condemns intoxicants as "Satan's handiwork" and admonishes Muslims to "eschew such abomination that ye may prosper."

The Taliban's lax enforcement of those Koranic injunctions makes its regime less Islamic than in other Muslim countries that show zero tolerance for illegal drugs. In Afghanistan, Rashid said, the maximum penalty for drug trafficking is 20 years in prison. In Saudi Arabia, whose version of Islam is similar to the Taliban's, it is death.

The WAsHington POST

MAY 11, 1997

\section{Hekmatyar tries to restore his lost credibility}

PESHAWAR - Engineer Gulbadin Hekmatyar has once again initiated effoits to restore his lost credibility in order to take advantage of current developments in Islamabad. He got published his interview in Pushto and Darri languages in daily Shahdat and rlaily Wahdat in which one of his spokesman unveiled an alleged conspiracy engineered by Alımad Shah Masud to kill him.

Hekmatyar in his detailed interview with Hizbe Islami's daily Shahdat said", Reconciliation with Ahmad Shah Masud was my blunder". He added that after reconciliation Masud had failed to fulfil his commitments to him. He termed Ahmad Shah Masud as a power-hungry person and held him responsible for killing of innocent Afghans, destabilishing all instituions of the country.

Referring to Ahmad Shah Masud's allegations that Hizbe Islami is responsible for fall of Kabul to 'Taliban, Hekmatyar said, everyone knew that who was responsible for defence of the Afghan capital. He alleged that inspite of fighting, against Taliban Ahmad Shah Masud was busy in hatching conspiracies against him. He was of the view that before facing Taliban Ahmad Shah Masud was desirous of crushing the Hizbe Islami forces.

Hizbe Islam's (HIA) Qareebur Rehan Saeed in another interview published by Pushto daily Wahdat on Monday claimed that a murder plot engineered by Alimad Shah Masud against Hekmatyar was foiled when HIA mujahideen apprehended two persons. The accused identified as Ahmad Ali and Zamary had confessed their crime. Mr Saeed claimed that Ahmad Shah Masud and Gen. Rashid Dostum considered Hekmatyar and Ustad Rasool Sayaf as a serious threat. He said for this purpose they were engineering conspiracies against both the leaders known for hardline attitude in the region.

Hekmatyar, however, expressed his reservations over policies of Taliban but his party's spokesman exposed a soft corner for them.

Commenting on recent political developments in Islamabad, Hekmatyar was jubilant over return of Mian $\mathrm{Na}$ waz Sharif into power. He said that it was need of hour that Mian Nawaz

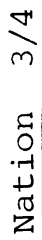

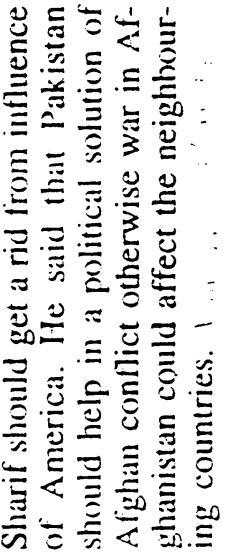




\section{By MAK Lodhi}

Lahore -he trade of lethal drugs fo: arms d vehicies kept thrimn: tnrournout 1996 in the Golden Crescent mainly because of a sustained poppy cultivation in the civil war. com Afgranistan, leaving Pakistan as an afficted country as one of the worids biggest consumer markets For illicit narcotics, drugs and a conduit for trafficking to the outside world.

According to estimates prepared in a recent situation report by the United Niations Drug Control Programme (UNDCP), poppy was harvested from $55.000-58.000$ hectares in Afghanistan in 1996 which is slightiy higher than 54.000 hectares harvested in 1995. The cultivation of the crop in Pakistan. however. declined from 4.709 hectares 1995 to $.038 \mathrm{Ha}$ harvested last year mainiy because of continuous government and donor aided efforts in supply reduction.

A survey by The News Bureau of investigation (NBI) with interviews of senior officials of Frontier Corps, Baluchistan and ANF field officers show that drug traffickers have found two new routes after Heimand in Afghanistan emerged as top poppy producing area. eclipsing Nangharhar where poppy production has declined.

Accordingiy: drug barons. operaiing from Middle East states, have found new routes and destinations for drug traffiching. The clandestine mobile laboratories for processing opium in. morphine base and graded he $\therefore$ are now shifting to Afghan border with Central Asian Republics from Pakistans Khyber Agency where they are reported to nave been destroyed in December, 1996.

The drug traffickers now follow wo new routes explored mostly in 1995-96. The first choice is Central Asian Republics where the traffichers find fewer restrictions.

About traffiching through Centrai Asia. according to the UNDCP. the new drug production and processing zreas winich are reportediy emerging $n$ the Central Asian Republics when zombined with the displacement of rafficking northward from Ighanistan, to Russia and to EuroJean market represent matters of seious concern.

The second route is more teiious. The merchandise is transorted by vehicles along Afghan borer to Baluchistan. A small village in aluchistan. Girdi Jungle (Chaghai). where Afghan refugees camped during Aghan war, is the hub of the twoway illicit trade for drugs, arms and illegal vehicies.

It is here that many transactions take places. bargains struck and payments made. According to ANFs well-placed sources, the transactions in dollars. the onjy currency in vogue for the pavment of heroin. can be higher than the unofficial foreign currency trade markets of Lahore and Karacni where business is mostiy telepnonic.

From Girdi jungie, illicit drugs including large quantities of hashish are carried on camelback. lorry and motorcycie through inaccessible mountain terrain to the Mekran coast. The traffickers contracted to haul the contraband through the rugged regions, are equipped with anti-aircraft guns. rockets and wireless sets. No sooner do they reach Mekran coast than they find speed boats in readiness which transport the merchandise to sinips waiting in deep seas. The speedboats usually hoodwink the slow-moving boats of coastguards who can neither chase nor cover the entire length of the coast.

After two major seizures by ANF, an organization officered by motivated Army personnel, big caravans have given way to small ones.

According to UNDCP, Europe and to a lesser degree the United States of America. are destinations for higher grade heroin opiates exported from this region.

The other route diversion is to carry the drug through land via Iran which, assisted by international agencies like UNDCP, has spread out far stricter anti-drug net. After increased vigilance by Iran the route is no more a pleasant choice for traffickers although the cost in Iraniar law enforcement lives has been high.

However, the drug trafficked-via iran to Turkey and onwards is morphine base which is converted intc high-grade heroin in superior labo. ratories situated in Turkey (Soutr eastern Turkey and in the suburbs o Ankara) and other countries.

The brown grade heroin sold in Pakistan is produced in laboratorie: in Khyver Agency. Pakistans larg, seizures in 1995 (figure 2) resul from one large raid in March tha year on heroin producing labs is Khyber Agency, says the UNDCP re port

The NBIs own studies snow tha the initial interest shown by the PPF government till 1995 had the revivit of US military and economic aid as its main motivating force behind it. Once the objective was achieved, the governments attention was diverted to more mundane issues. The figures for seizures during the first nine months of 1996 aiso show that the interest dissipated.

Another reason for lukewarm response by Pakistani law enforcement agencies to check drug trafficking to foreign destinations is their personal disinterest and apathy towards affliction of foreigners. Drugs transported outside bring money to the country. It is not Pakistanis who invented heroin and those who did now pay for it, remarked an official. In his view, the Western countries should assist Pakistani agencies for vigilance equipment such as patroliing vehicles and air surveillance.

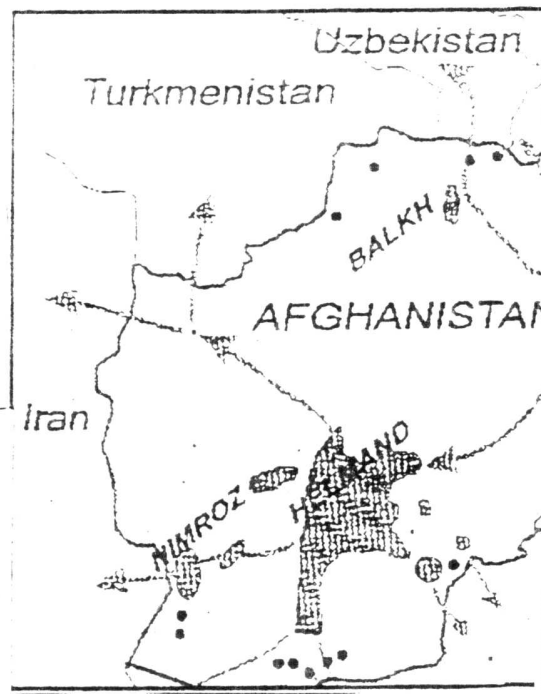

The facts speak otherwise, howeve. Pakistan itself has been the worst victim if the figure of $1.5 \mathrm{mil}$ lion heroin addicts is true. Pakistan has been able to set:up oniy 179 Treatment and Rehabilitation Centres (NWFP 25; Puivab 87, Baluchis$\tan 12$, Sind 55 ) in both private and public sector. Comparativeiy: the United States. with a population only twice as large as Pakistans, boasts well over 10,000 T\&R centres. For a poor country like Pakistan. this amounts to a big social disaster.

One reason for the debilitating figures is the poor response shown by law enforcement agencies. Even those which seriousiy want to engage themselves in the task, like the reconstituted Anti-Narcotics Forces, complain that Baluchistan Levies working under political agents, and police officials, lend little cooperation and even leak information for conducting raids as their manpower is always required.

According to UNDCP situation anaivsis, estimates of total opium production in the Golden Crescent is 1995 came to about 2:175 metric tons. Out of it, 2,066 $\mathrm{mt}$ was produced in Afghanistan while Pakistar contributed $109 \mathrm{mt}$ only. The tota. seizures made by Iran and Pakistar during 1995 came to $485 \mathrm{mt}$ opium equivalents. This figure in cludes $236 \mathrm{mt}$ of oplum. $12.8 \mathrm{~m}$. heroin (equivalent of $128 \mathrm{mt}$ opium) and $11 \mathrm{mt}$ of morphint base(equivalent to $110 \mathrm{mt}$ opium).

The UNDCP figures are comparatively low and seem to be factually based compared with figures of a US government report released last week.

An alarming fact, however, is that during the nine months of 1996 oniy $92 \mathrm{mt}$ of opium. $4.3 \mathrm{mt}$ of heroin and $4.6 \mathrm{mt}$ of morphine base was seized by the two countries against a poppy

iankistan coma
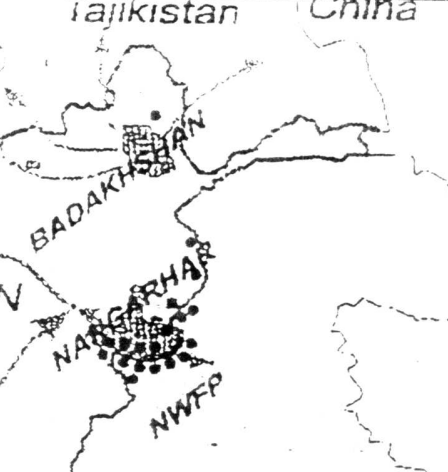
(

\section{Pakistan}

harvest which didnot decline in the same year. Unless vast quantities have been seized on the northern Afghan border (winch has not been reported), there has been massive stockpiling; more drugs have been available for consumption in the nome market and for transportation abroad.

The interdiction rate of 22 per cent acquired-in 1995 is therefort feared to have gone down.

The UNDCP situation analysis ir. dicates another atarming fact. Cases of heroin injection have begun to emerge in not only Karachi but in other large metropolitan areas in Pakistan. The practice, previousiy unknown in the region, has been observed in recent studies and raises concern about the increased risk of transmitting blood-borne diseases, such as hepatitis and HIV/AIDS through the process of needle sharing, says the report.

The new government, it appears. will have to show its teeth. Harsher legislation and stricter vigilance apart, it will have to make a big effort to deliver 1.5 million heroin addicts in the country and turn them 

to its workforce througn a niror- enabilitation programme. This ands apart from the far greater needed to improve prevention nwareness programme to stop Dermentation in the first viace. eports of Patistans inteligence gencies ats o bear out that it is laun- ered drug money basicaily which is curned and utived in the snape o! egal arms and antl-state sectanan errorism. As has been demon- rated eisewhere in the worid. drug rafficing thrues in a country is aced with a grave law and order sit- racion.
In the top ot a needed assess- ent of the impact of the crug econ- on Pakistan. a fresh look at the oblem of Afghanistans ciril war is so expected uy Vawaz Sharifs gov- nment. Without its proper solu- on. the drug barons, calling shots rom outside the country are likely continue to eat into the ritals of he state
Ews (zakistan) $3 / 6$
By KENNETH J. COOPER WASHINGTON POST
KANDAHAR, Afghanistan - Ahmed Gul, a poppy grower in south- ern Afghanistan, picked up a rusty mortar shell from a poppy field. walked over to foreign journalists nearby and declared: "We are culti- vating this because the Russians used this weapon. Now, we are cultivating and exporting this as an atom bomb."
Helmand Province, which pro- duces about 60 percent of the poppy crop, was the country's breadbasket until an extensive irrigation system built with U.S. aid fell into disrepair - like most of Afghanistan's infra- structure - during two decades of warfare.
There was all this wheat and all this cotton, and now it's all this poppy," said William Bergquist, a United Nations official based in Kan- Jahar.

\section{Taliban's militia tithing may be rooted in opium}

Geddes said the United Nations has tried to persuade poppy growers they can make as much money from fruit orchards, onions and other vegetables. Under another U.N. program, local leaders will be asked to ban poppy cultivation in their areas in exchange for a development project of their choice.

Both the State Department and the U.N. have reported that the Taliban collects a 10 percent tax on opium. poppy.

Abdul Rashid, drug-control director for Kandahar Province, denied the militia taxes poppy growers but said local Muslim clerics might receive the tithe. One Afghanistan specialist doubted the poppy tax is a major revenue source for the Taliban, which has received the bulk of its war resources from other Islamic fundamentalists in Saudı Arabia, the United Arab Emirates and Bahrain.

\section{2)

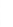 .

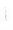

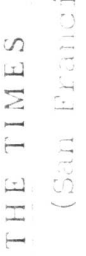

\section{Taleban just says no - and yes - to drugs}

\section{By Ahmed Rashid} LONDON DAILY TELEGRAPH

KANDAHAR, Afghanistan Opium production is soaring in Afghanistan as farmers benefit from the relative security that the fundamentalist Islamic Taleban movement has brought. two-thirds of the country, has imposed a strict ban on hashish growing. But it has declined to ban poppy production, from which opium and heroin are made.

Taleban leaders say hashish is consumed by Afghans and is therefore anti-Islamic. But as opium is exported to the West and there is no cash-crop alternative for farmers, there is no urgent need to ban poppy growing.

"We let people cultivate poppy because farmers get good prices," said Abdul Rashid, head of the Taleban's Drugs Control force, at who wears a flowing black turban and a long beard, has a 10-man force that was set up a few months ago.

"We cannot push the people to grow wheat," he added. "There would be an uprising against the Taleban if we forced them to stop poppy cultivation."

Mohammed Hassan, the governor of Kandahar who is the Taleban movement's second-ranking leader, said: "Drugs are evil, and
The Taleban, which controls his office in Kandahar. Mr. Rashid,

\section{Bans hashish but allows poppy crops}

we would like to substitute poppies with another cash crop. But it's not possible at the moment."

The Taleban's ban on hashish production, largely because it is consumed by millions of Afghans, already seems to be taking effect. Hundreds of sacks of hashish are stored in two warehouses at the police headquarters after it was confiscated from growers and dealers.

The Taleban also has a novel approach to hashish addiction.

"When we catch hashish smugglers or addicts, we beat them to find out the truth," said Mr. Rashid. "Then we put them in cold water for hours, three times a day. It's a good cure."

In the presence of Mr. Rashid, several prisoners readily agreed that the Taleban's shock therapy was effective.

"When I am beaten or in the cold water I forget all about hashish," said Bakth Mohammed, a former shopkeeper who is serving three months in jail.

Last year Afghanistan produced an estimated 2,300 tons of opium, rivaling Burma as the world's largghan dealers, as well as those from Pakistan, Iran and Turkmenistan, buy the raw opium and refine it into heroin for export.

Officials of the U.N. Drugs Conest producer of the raw drug. Af- trol Program said that in 1996. Kandahar Province produced 120 tons of onium, harvested from 1,317 acres of poppy fields. The previous year, 72 tons was produced from 1,02.5 acres

Just two miles from the city center, poppy fields stretch as far as the horizon. This year, farmers have brought in fertilizer and new tractors from Pakistan to increase their crop yields. ()ld irrigation channels, dectroyed during the war against the Sovict occupation in the 1980), are being rapidly restored.

"The Taleban has hought us security so we can grow poppy in peace," said Wali Jan, a farmer, as he weeded his field of still-green poppy plants. "How can I support my 14 family members if I don't do it?"

On his small plot wf hand, Mr. Jan produces about 100 poumis of raw opium from two crops every year and earns the equmbicnt of about $\$ 1.275$. Refined hernin fetches 50 times that price in $\mathrm{l}$ ondon or New York.

Nud homes are heing rapidly rehuilt on villages around Kandahar from the proceeds. The trade is a huge incentive after the devastation if 18 vears of war

"I have stopped growing hashish recause the Taleban has forbidkn it," said Abdul Karim, another farmer. "When the Thleban leaders ask us to stop growing poppy: we will obey their command."

The Taleban is angry that the vorld has still not recognized ita government even though it controls most of Afghanistan and the capital, Kabul.

The UN must recognize our government because we control 75 percent of the country and we re pect human rights. "Mr. Hassan and.

Taleban soldier, Abdui Ma teen, said: "If the West will support the Islamic demands of the Taleban and recognize our govern ment, then we can stop this poppy cultivation

The lack of recognition means that international aid from Western drug-control agencies is virtualy nonexistent.

This office should be supported with equipment from forrim countries to control drugs. said Mi Rashid, the head of the inug-control force. "But I have only 10 men and a sconter to chase bashish smugglers

The Talchan's refusal to shate power and its discrimination against women have been major factors in the lack of recognition forn Western and Muslim countries. Now, in addition, the growth in opum production is causing mcem in Western capitals.

- Distributed by Scripns flowari 


\section{Afghan giris mostly kept rom school}

ZABUL, Afghanistan - on a nondescript reet in southern Kabul stands a nondescript ila with a smail courtyard

ut the Aschiana Center is speciai because months after the Taleban militia captured Afghan capital, it's the only institution in in that continues to educate giris.

emale education, employment and free moility largely have been extinguished novement that espouses a rigorous version of hariah law. The Aschiana Center survives only ecause it bills itself primarily as a refuge for treet children. So the mullahs, who recognize his role in a city that has been a war zone for eariy five years, turn a blind eye to its seconary function as a school.

Iany coeducational schools were forced to when the Taleban seized power in Septemand ordered out female teachers. Then wincame, and, in accordance with tradition, the maining schools closed until the spring. Next month boys will start back to school, but eir sisters will stay home unless parents dare send them to one of the clandestine schools hat have been set up in private homes - parcularly by the Hazara minority, who regard ducated women as more eligible for marriage.

The Aschiana Center has space for just 250 children - boys and girls are segregated for essons - and these are just a handful of the 8,000 youngsters who were estimated by the viss nongovernmental organization (NGO) erre des Hommes (TDH) and the U.N. High ommissioner for Refugees to be working on abul's streets last year.

The Taleban restriction on women - they are lowed to work only in the heaith sector or as egars - means that more and more families dependent upon children as the main eadwinners

The pupils at Aschiana are no exception. hey continue to support their families by vashing cars, polishing shoes, selling food or ollecting. firewood and scrap. But between hores they come to the center to get breakfast, wash and lessons in health education, math nd Dari, the main language of Kabul.

Before the Taleban marched into town, the enter accepted girls up to the age of 18 , the age of majority for both sexes under Afghan statute. harian law decrees a girl's childhood to be over t 14 - it's 16 for boys - while the Taleban says ne is a woman at 7 and should not mix with fter that age.

"It took about two months to get permission rom the Taleban authorities to let even the mall girls back to the center," said TDH deleate Nick Hughes. "However, many of the girls re so undernourished that a 10-year-old can ass for 7 and still be allowed in."

The Taleban's distinction between the sexes, long with the otherwise blanket ban on female iucation, has divided the international donor mmunity. The United Nations Children's nd (UNICEF) suspended all assistance to education in Taleban-controlled areas in Noember 1995 on the rrounds that the policv ontravened the Convention of the Rights of the hild.

But the Swedish Committee tor Afuhanistan las argued, with support of many Afghan VGOs, that bovs snould not be penalized beause of the Taleban's views.

The Taleban has said that it will review its osition on education for giris once its military yoals have been achieved. But the reopening of firis schools will not be enough to silence the international outcry if the curriculum is patterned on the religious schools that spawned the aleban movement

Donors won't have any objection if there are classes about religion so long as there is some practical education," said Paui Barker of the charity CARE, which supports 38 "home schools" in Taleban-controlled provinces south of Kabul. "I think the Taleban will come to reaiize that there are some valuable skills which come out of a secular or broader based education.

It the ministerial level, more technocratic Taleban are sensitive to criticism but fear alienating their rank-and-file supporters, most of whom are recruited from more conservative. asntun areas from southern Afghanistan.

That is the reason they have taken such hard line in Kabul," said Mr. Barker. "If they had come into Kabul and let everything continue the way it had been before, what would their foot soldiers, who are going off to die in the trenches, think?"

Even before the Taleban held sway over education, enrollment of girls was a mere 3.6 percent of the school-age female population. But

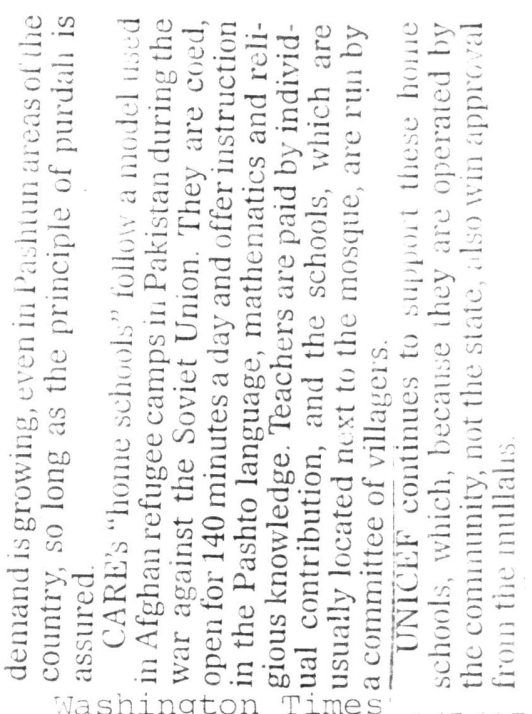

In

same issue, UNICEI

"implausible" thei

ment that there was not

enough money to orovide

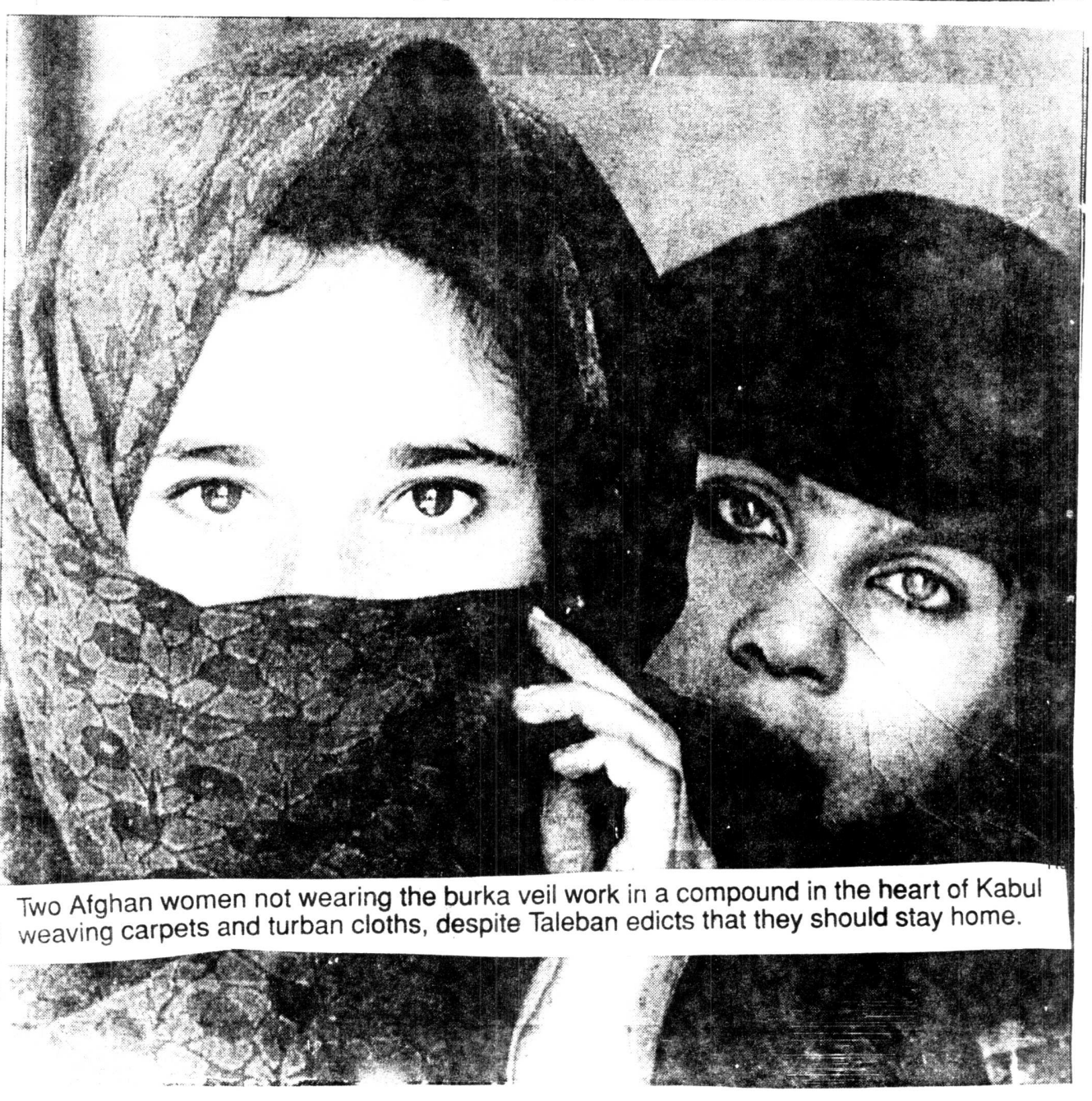




\section{Schooling of Afghan girls goes ahead}

\author{
By Marc Kaufman \\ NQUIRER STAFF WRITER \\ KHOST, Afghanistan - one by \\ ne, the carnest young bovs and \\ giris of the village school made \\ their way to the front chaikboard. \\ received their question, and began \\ 10. write. \\ $" 8 \times 6+12=60$," one round-faced \\ boy transcribed slowly and care- \\ fully. A lanky girl with black lines \\ of kohl around her eyes recited a \\ noem, then wrote it out in the Dari \\ iialect. Another girl, shawl over \\ her head, attempted some grammar. \\ There was nothing extraordinary \\ or untoward about the schoolhouse \\ scene - except that it is occurring \\ venly in Afghanistan. on an ex- \\ osed hillside in a section of the \\ country that the Taliban Islamic \\ Movement has controlled for almost \\ wo years.
}

The fundamentalist Faliban. was been widely reported and lamented, does not allow giris to go to school. And if it ever did allow girls to be educated, it certainly would not be alongside boys.

But here in Khost, more than 30 coed schools are now up and running, teaching thousands of Afghan children. Many of the teachers are female - despite strict Taliban rules against women working.

The schools, believed to be unique in Afghanistan, were organized over the last two years by CARE International, with the help of a former Afghani administrator from Kabul University.

If the people want the schoois will pay for them, and will follow some very general rules, locai Taliban officials told CARE representatives, then they can have them. Today the schools are largely financed by local villagers.

They offer only basic education, the equivalent of a second- or third-grade curriculum to children sometimes as old as 14. Each school has just one teacher in one classroom, but some are ready and eager to grow.

"We are very pleased with this program and expect to expand it significantly," Stuart Worsley, CARE's assistant country director for Afghanistan, said during a recent tour of the schools.

Given the intensity of the Taliban's embrace of purdah, or separating men and boys from women and girls, this seems impossible. UNICEF and other international agencies have closed most of their education programs in Afghanistan because girls were not being allowed to attend.

But in Afghanistan, a wild and mountainous place where resistance to unpopular rules and laws is second nature to many, the impossible often has a way of becoming possible. Afghans, atter ail, accomplished the imnossible by resisting the Soviet Union for 10 years and finally forcing its 115,000 soldiers 10 withdraw in 1989

Faced with widespread resentment against rules keeping girls out of chool, top Taliban officials have besun to moderate their policies. Last month, Taliban radio reported that the nation's leader, Mullah Mohammad Omar, had said the Koran did not prohibit the educating of girls.

But Afghans are not waiting for official approval from Taliban leadrs in Kabul, especially in areas of relative autonomy outside Talibancontrolled cities.

"The Taliban, they are illiterate people, sometimes ignorant people, said former mujaheddin commander Mohammad Ibrahim, whose children attend the coed hillside school outside Khost. A dignified man with a long beard and quick smile, he said many of his neigh. bors agree, although they may not be willing to express it.

"The Talibs do not know Islam or the knowledge of this age," he said through an interpreter. "So when it comes to schools, we will do what we think is the right thing.'

And for this father of two daughters and three sons, that means educating all his children for as long as possible.

Afghans put enormous weight on education, and educated peopie wear their accomplishments with great pride. The honorific "Engineer" is used like physicians in the United States use "Doctor," and everyone here claims whatever title he can. Mohammad Ibrahim, for instance, was trained in first aid during the war against the Soviets, and now calls himseif "Doctor."

On the other side of Khost, on a dusty plain broken up by mud-wall compounds, boys and girls are learning in another CARE school housed in a surprising location: A newly constructed mosque and guest room.

The structure went up several years ago thanks to a well-known local mujaheddin commander, Jalaluddin Haqqani, who has close ties to some Persian Gulf sheiks. Haqqani has now joined the Taliban, and is fighting alongside it in the north of Afghanistan.

Coed schooling is probably not what Haqqani or his gulf sponsors pected for the new mosque guest om, but that is what the people o: ie village, Peeran Worza, say they want

"Because ol war, our children and grandchildren never received the education they need," said gnarled former mujaheddin fighter named imerdin, who had one laughter and four grandchildren in the school. "For boys and girls to be together is no problem. They are 10 gether in the village all the tme.

If Taliban officials ever came to the school and told them to expel the girls, Amerdin and another wllage father explained, "we'd just tol. them to go away."

Around Khost, perhaps the most startling and assumption-shattering school of all is offering classes in a iarge army-style tent, between the mud wall surrounding a family compound and nearby fields.

Boys and girls are learning side by side. but here their teacher is a woman - and one who used to reach schoois in the capital of Kabu! when it was run by the communist government of the late president. Najibullah, who was executed by the Taliban in September.

The teacher, Cobra Zarif, left Kabul with her sociology teacher husband after it became unwise to be associated with the former communist government. But in her village outside of Khost, she is not only teaching boys and giris, but also teaching the sons and daughters of the mujaheddin fighters who bat tled long and hard to defeat the communists.

She said her village approached local Taliban officials with a request to open a CARE-related school, with Zarif as the teacher. more than a year ago, and that the Taliban offered no objections. "So far," Zarif said. "we can see no problems." .

Zarif's husband, Mohammad, said a key to the school's success is its location two miles outside of Khost. a provincial capital that was destroyed during the war but is now being quickly rebuilt. A huge threestory mosque, said to be the largest in Afghanistan, is under construction there, sponsored by Persian Gulf sheiks

"If the Taliban did come, we will just show them what we are doing," added Cobra Zarif, who wore a scart over her head but not the head-totoe covering of a burqa, which the Taliban favors. "Nothing here is against Islam; it is the opposite. The Koran says for children - boys and girls - to seek for knowledge.'

The teacher said she had great plans for the school and its boys and girls. "We would be very happy if this turned into a university.". she said.

THE PHILADELPHIA INQUIRER 


\section{Women in Afghanistan}

IMAGINE NOT BEING atle to leave your home or go to work without fear of being publicly beaten. Or imagine that by dressing 'inappropriately', you risk physical assault. Imagine, even, that you might be detained solely by reason of your gender. And imagine that you confront these fears every day solely because you are a woman. This is the reality for many women in Afghanistan today who are at the mercy of various armed political groups battling for control of the country.

III 1995 . Al's report on women in Afghanistan revealed that women have suffered through a civil war which has ravaged their lives and homes in complete disregard of humanitarian law. As decades of violence continue, women have been victims of violence, conflict, and religious strife although they play the least active role in the hostilities. Women have been treated as spoils of war and subjected to rape and other forms of torture. The international community has ignored the situation of women in Afghanistan for too long.

\section{THE TALEBAN FORCES}

The most recent development in this tragic conflict is the emergence of the Taleban as a military and political force. The situation :or women in Kabul under the former Mujahideen leaders was never ideal. The government, which was headed by President Rabbani, was far from advocating the rights of women. For example, it prohibited the delegation to the Fourth World Conference on Women in Beijing from attending at the last minute because it was decided that the conference would promote "immoral and unIslamic behavior". In addition, members of Afghan women's organizations, such as the Revolutionary Association of the Women of Afghanistan (RAWA), which are not affiliated to any political group, have persistently faced harassment and death threats from Muiahideen groups. Mina Keshwar Kamal, a founding member of RAWA was murdered in Pakistan in 1987. monedy by members or an Afghan
When they do venture onto the streets, women must wear the allenveloping burqa, which allows only a mesh opening over the eyes. White socks are also out, possibly because they might attract male attention.

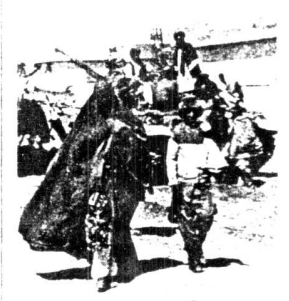

Armed internal confict. Afghanistan 1995. c. Steve Dupon:

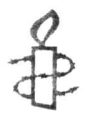

en's human rights are not violated only by one political group. Although each armed faction has perpetuated the illtreatment of women, the Taleban appear to be more successful at enforcing restrictions on the livelihood of women than Mujahideen governments were in the past.

The Taleban currently control about two-thirds of Afghanistan's territory as well as the mechanisms of government in the capital. Kabul. The Taleban have stated two broad aims which are first to disarm all warring Mujahideen factions which they believe are corrupt and secondly, to impose on Afghanistan their strict interpretation of Islamic law. Taleban forces appeared at first to be able to impose discipine and order upon their emergence. However, this perceived order and stability has a significant cost in terms of the man rights of women. of women have been physically restricted to their homes. They are not allowed to go to work or leave their homes unaccompanied by a close male relative. Girls are not allowed to go to school. The imposition of strict Islamic law by the Taleban has in principle denied women some of their most fundamental rights - including the rights of association, freedom of expression, and employment.

\section{CRUEL PUNISHMENTS}

Taleban edicts ban women from going to work. This has had an overwhelming impact on the health care system in Kabul. As female nurses form the backbone of the health system, their inability to work has seriously impaired the capabilities of health services. Nurses who had gone to help their patients in early October 1996 were repeatedly beaten by Taleban guards. In one hospital, the Taleban reportedly told all 80 female patients to go home as their modesty could not be preserved in an overcrowded ward. Amnesty International was informed by a visitor to Kabul of the plight of two Afghan nurses who were assaulted by the Taleban and beaten. The nurses were toid by Taleban officials that they should continue to work at a certain hospital while others had been sent home. On 30 October, the Taleban official in charge of the security area - reportedly a I7-year old youth - came to the hospital. Upon seeing that the two nurses were not wearing burqas but were only covered with scarves and long coats, the Taleb became very angry and dragged the two women to a tree nearby and began beating them with a tree branch. When one tried to run away, the Taleb forced her onto the ground and held her in between his feet while beating her with a stick.

Countless women have been beaten in the streets for not wearing a burqa - a garment which covers the body from head to toe with only a small, lace-covered opening to look through. Women who show even an inch of a bare ankle are at risk. On 4 October ig96. The Guardian newspaper published a story about three women who were brutally beaten because a few inches of bare leg were showing above the women's ankles. An eye-witness reported to Amnesty International that a Taleban guard severely beat a woman who had gone out of the house without wearing a burqa, even though she cried out that she could not afford 
in Herat, Kabul, and other maior provm. cial centers of Afghanistan, the impact of Taleban restrictions has been acutely teit. In these cities, there are a significant number of educated, proressional women. Kabul University, which has losed since the Taleban takeover, reportdy had 8.000 women students. In the ity, professional women made up a sizble part of the workforce. Rules in these ities were also fairly 'relaxed' relative to ther areas of Afghanistan. The sudden imposition of Taleban rule undermined the professional and academic lives of these women. In Kabul under the Talean, there is also concern about the mpact of their edicts on the estimated 25,000 to 30,000 widows, many of whom are the sole providers for their amilies. These women have been hit articulariv hard by the ban on women working. In addition, those widows who do not have any close male relatives to accompany them in public may be in the position of not being able to go outside without fearing punishment by the Taleban. Working women in Herat and Kabul protested in vain against the rigid code the Taleban imposed. When the Taleban entered Herat in September I995, they closed certain government departments, women's public baths, and girls' schools. Hospitals were closed for two or three days. They were then re-opened because they realized that female mem. bers of the families of Taleban needed medical treatment.

\section{NTERNATIONAL AGENCIES}

Policies which restrict the rights of women have drawn criticism from UN relief programs and international aid agencies in Afghanistan. In I995, UNICEF suspended its educational programs in Taleban controlled areas because the Taleban's opposition to education for girls violates the UN Convention on the Rights of the Child. In March Ig66, a number of non-governmental organizations also suspended their humanitarian programs in western Afghanistan. Save the Children-UK stated that the new restrictions on women's employment, which was already limited in any case, removed all opportunities ior humanitarian organizations to consult and communicate directly with fohan women. The Britich aid orean: zation, Uxtam, suspended its program when the Taleban stopped their female staff from working. The restrictions of the Taleban on women's work has everely curtailed organizations working outside the health sector. Agencies have noted a cramatic increase in mine-relat edinjuries, for example, suffered by women and children following the prohibition of women's participation in mine awareness programs and the closure of schools by the Taleban.

\section{INTERNATIONALAND REGIONAI RESPONSIBILITIES}

Women in Afghanistan have continued to work and study outside their homes.

They have demonstrated in the streets to protest the denial of their rights. But they are aiso attacked, beaten, detained. raped, and tortured because of these activities. Afghan women, as well as the rest of the civilian population, are in desperate need of an environment in which their human rights are respected. All warring factions in Afghanistan are responsible for the cycle of abuses and lack of respect for humanitarian law. The international community is responsible for finding and implementing solutions to enc the suffering of Afghan women. The powerful countries supporting the Taleban include the United States, Saudi Arabia and Pakistan. Amnesty Internationai believes that governments who supporthese warring factions, particularly those who have supplied arms to the conflict. have a responsibility for their conduct in the field of human rights. They are answerable for the policies and practices of these groups which violate fundamental human rights. AIUSA and other $V G$ Os have forcefully raised these human rights concerns with top officials of the Clinton administration and continue to arn against legitimizing the wom en's h.mman rights setbacks represented in the Taleban policies.

\section{US CORPORATE SUPPORT}

Unoca. which has consistently done business with the military junta (SLORC) in Myammar, dismayed the human rights community by publicly endorsing the Taleban. On Oct. 3,1996, Reuters repores that "the U.S. energy company Unoca. Corporation which is seeking to
Guld a gas and an oil pipelme an :oss Afghanistan from Turkmenssa: to Pakstan. sald that the Taleban wotones were positive development. Chrs ice President of Unocai Intem.tonat Energy Ventures Ltd.. said. "we ward it the current situation in Atghanstanl as very positive... I understand Pakitun has already recognized the Taleban sournment. It the USA follows, it whll thad the way to international lending agencies coming in." Please use the enciond model letter text to protest Lnoca s state ments. To obtain a copy of Al's report on Women in Afghanistan and/or a copy of the Io96 AI report entuied. Afghanistan: Grave Abuses in the Vame of Religion". contact AIUSA Pubrications Department, 3228 th Avenue.

$10001 .+$

INTERact WINTER I997

AMNESTY INTERNATIONAL USA 322 Eighth Avenue NEW YORK, NY IOOOI

\section{Afghan women endure} brunt of Taliban rules

The bearded Taliban riding in back carry a stick in one hand and a Kalashnikov rifle in the other, ready to beat any woman breaking their rules.

On a single recent day, religious police beat six women for various transgressions - the worst being a woman who allowed her arm to be seen. For that offense, she was dragged from her vehicle and beat publicly.

"This is essential so that other women will observe hijab [the full covering]," said Haji Kalahuddin, head of the Taliban religious police.

On another day, the religious police beat 24 shopkeepers and taxi drivers for dealing with - women who were not wearing burqas.

Two French male aid workers were jailed for 26 days for min. gling with Afghan women. They were released, but five Afghans charged with them are still in jail and will receive up to 29 lashes as punishment.

Mullah Muhammad Turabi, a cleric who flies into a rage if a woman is in the same room, has been appointed by the Talibarr's supreme commander to establish the code of behavior for Afghans - including men. 


\section{Women call for mmediate end to Afgnanistan inghing}

Trom Shamim Shahid

PESHAWAR - in connection with the Universal Women Day, the war affected educated civilised and democratuc minded women from Afghanitan arranged gatherings in Pesnawar with a view to divert attention of the vorid countries towards their grievances.

The Peshawar based Af ghan Women Council arranged a gathering at Arvana Afghan School Hayatabad. Pesnawar on Saturcay. While the Revolutionary issociation Women of Afghanistar. RAWA) arranged a gathering $\therefore$ Cherat area in the afternoon. The Gayatabad gathering besides a large umber of Afghan women. associatec vith health and education fields was rtended by scores of those womer ino had left their homes after estarsning of Taliban's ruie in Kabul and now living under the open sky at NasaBagh and Akora Khattak Refugees camp.

The Afghan Women Council's meeting in connection with Women's Universal Day was presided over by Fatana Ishad Gillani and beside her it was addressed by Mohtarama Shafiqua Seraj, Dr. Zohra Jan, Dr. Alama Jar. Nadia Naij, Spogmay Hemat and others.

Before delivering speeches, the AWC Teaders and stalwarts also proyided an opportunity to the war atfected women to describe in dept their grievances. The Afghan womer. mostly the widows informed that the vere facing snelter. cloth and food roblems. They pleaded before the xorid countries. particulariy the United Vations to provide them treatment taciities.

On behaif of the Afghan Women Council. Fataná ishaa Gillani and Yohtarama Shafíaua Seraj distributed gif packets among the women residng in the rerugee camp. Mohtarama Shafiqua Serai is the younger sister of ate Ghazi Aman Lllah Khan.

Addressing the gathering. Presicent of the Afghan Women Council Fatana Ishad Gillani said that it was astonshng that heroic Afghans who bat cefeated former Soviet Union like force now passing through severe economic and social problems. Durng occupiion of the red-army, the women lost heir husbands, sons, brothers. Simi-

However, Taliban after capturng Kabul buried orutaities of the Red Army communists and Mujahideen. She said that now the Afghan women who lost their bread-earners are not ailowed to come out of their homes.

Fatana Ishaq Gillani said that Isiam allows the women to get education and earn iivelihood through an honourable iob. However. the Afghan war lords had ignored said giorious guidelines of the sacred religion of Islam and deprived the Afghan women of their iust Islamic rignts.

Sine urged the Afghan rulers to revise their policies and let the war affected

omen gat education and serve their motheriand in various capacities. nen Muiahideen entered Kabul.
The President of Afghan Wiomen uncil was more critical towards the nuct attons. United States merci mu nther develoned counres whe suc that atter gettme ther blectives they ignored the Afghans. the and that all these forces nad sxtenued tremendous heip to Afrnans wile thev were fighting against the ked Amy and communists. But atter vilapse of the former Soviet Lnion. he US A and its allies ignored Afghans who now begging a two-time dry bread in all over the world. She urged the United Nations, United States of America and other deveioped countries to come forward and heip the Afguans at tis crucial stage.

Fatana Ishaa Giliani also expressed concern over ongoing bloodshed. and confrontation among the Afghans and repeated her ciemand for an early negotiated solution to the conflict. She said that war is no solution to the issue herefore. sne called upon leaders from all over Afghanistan to stop fighting.

The RAWA function at Cherat was also focused on grievances of the war affected Afghan women. But the RAWA leaders held the radical and hard line Afghan leaders responsible for destruction of their motheriand. The RAWA leaders said that hard liners are bent on to destroy Afghanistan from every waik of life to come forward and initiate a joint struggie against these hard liners.

The participants in RA WA function also chanted slogans against Tailiban. Similariy, they accused Gulbadin. Sayyaf, Rabbani. Dostum and others the killers. But the RAWA activists didn't condernn Ahmad Shah Masud.

The Nation $3 / 9$

\section{BACKGROUND INFORMATION}

RAWA, a left-of-centre group which does not advocate violence, has been active for over a decade. It campaigns for women's rights and provides education and health facilities for women and children. It has set up a number of educationai and health programs in Afghanistan but has had to scale down these operations because of the threats it receives. Most of its operations are based in Afghan refugee areas in Pakistan. These include several well-organized schools in Peshawar and Quetta and a health centre in Quetta.

RAWA has been at the forefront of Afghan groups campaigning for women's rights in Afghanistan. It has continuously opposed the policies of the Afghan Mujahideen groups towards women and, since the advent of the Taleban in southern

fghanistan in 1994, RAWA members have been demonstrating against the Taleban's ban on women going to work and girls going to school. RAWA's demonstrations are attended by Afghan women only, but many Afghan men who support RAWA's cause usually stay in the background and provide security when necessary.

Concern for the safety of members of the Revolutionary Association of Women of Afghanistan (RAWA) in Pakistan has been heightened following the detention and torture of a RAWA sympathizer by incividuals reportedly linked to Pakistan's security forces. 


\section{Program bridges cuiltural fissures}

\section{Afghan women connect to new life}

\section{By Kimberly Winston}

REMONT - When they arwred from Atghanistan. they sere cut off by a gap in lan2uage. religion. customs and food. And. they were old - too old. many of them felt. to learn unci adapt.

Thev didn't understand television. thev didn't understand their own grown children. they were afraid to go out in traffic because they couldn't read the road signs," said Najia Hamid. who brought her elderly mother with her to Union City from Kabul in 1990. "These poor women staved at home."

But now. many of these elderly women are bridging the culural miles through the Afghan Elderiv Women's Program that Hamid coordinates.

The program's goal is to provide elderly Afghan women with the practical skills to adapt to their new hometowns. Some have taken Paratransit courses to navigate buses, trains and taxis: others have attended Fremont Adult School to take English as a Second Language classes: others have attended workshops on becoming U.S. citizens.

Perhaps most importantly, all have made friends with people in similar circumstances.

The program was started in November 1995 by 12 members of the local chapter of the Afghan Women's Association International. That group was founded in 1992 when some local Afghan women decided they "wanted to do something undort ou people outside



Gulalai Nasiri (left) greets Alia Hamid at a meeting of the Afghan Elderly Women's Program at the Fremont Senior Center.

the United States." Hamid said. After sending 85.000 pounds of food and clothes io Afghan refugees in Pakistan. the Afghan Women's Association decided to urn its attention to the problems of their people in the Bay Area.

Thev met with police about the problems of gang involvement and drug abuse among Afghan teens. And they met with teens to trv and estabish a way to link them to a culture and a country many left long ago and had little hope of seeing again.

Then they turned to the elderiv women among them.

In Afghanistan. there is respect for elders. the children know they must spend time with them. they are honored." Hamid said. "But here. society is completely changed for them. Their children are busv, out working, and their grandchildren are completely Americanized."

Many of the women are refugees who lost husbands, sons and brothers in the war with the Soviet Union that swept through their country from 1979 to 1989. Arriving in this country. they found themselves entirely dependent on their children or erandchildren who were learning English in the schools.
Many fell into depression. Hamid said.

Perhaps as many as 90 percent of these women are illiterate in Farsi. their own lanquage. Hamid estimates. How much harder, then, to try to learn English?

The first meeting of the Afghan Elderly Womens program attracted 25 members. Now, the monthly meetings have mushroomed to include 85 women from the Tri-Cities. Hayward. San Jose. Concord and even Modesto.

Hamid attributes much of the program's success to English classes provided to the women by the Fremont Adult School and to her recent affiliation with the Women's Health Leadership program. That group connected her with experts on the health problems of women in low in. come and underserved communities. Through that program. she has brought Farsi-speaking doctors to speak to the women about health, diet and exercise.

At the February meeting at the Fremont Senior Center. the women listened to speakers from the Social Security Department and the health and legal r) rofessions describe how the new welfare reform laws could

\section{effect them.}

The majority of the speakers spoke Farsi, and a translator was on hand to translate questions and answers for the nonAfghan speakers.

The women say the program has been a vital link to a new life

When I first got here. I can'to out. I don't speak the lan quage. so I am dependent on my son." said Shamsul-Banat Kabir. 69, who came to Fre: mont with her family in 1984. Now. I know how to take a bus to a clinic if I or my husband are sick.

\section{San Francisco Valley Herald 2/18}




\section{Afghans Cry Out For Education}

In the world map of $\mathrm{m}_{5 . . \mathrm{er}}$ education, the small Balkh University here may not figure prominently. But if there was a way of measuring enthusiasm for learning, the students and teachers of Balkh University could well be heading the list. In the midst of a long, debilitating civil war, motivation is perhaps the only thing going for Balkh University.

Against great odds, the students and the faculty of the University are struggling to keep their institution alive. The Taliban, which has occupied two-thirds of Afghanistan and now covets the remaining northern plains, casts a long shadow over the University.

"The young people here are afraid of the Taliban, that has banned education for girls and pushed the boys into a medieval barbarism", Ms. Ahmed, an English teacher at the university, said. The Taliban has reopened Kabul University, but girl students have been barred from its gates. Another young lecturer, Mr. Nasir, said "We thought the Taliban will end the war and bring peace". "But our illusions have been shattered. The Taliban wants to take us back to the stone age", he said.

Unlike in Kabul University, where the girl students have been banished from its portals, here at Balkh University there are large numbers of girl students and female faculty members.

Balkh University runs two different schedules to accommodate the many students who have flocked here from all over Afghanistan to pursue higher studies at Mazar-e-Sharif, the last sanctuary as yet out of bounds for the Taliban. The Afghan middle class has long admired university degrees. Many of them append "doctor" and "engineer" to their names, to declare their educational achievements.

While the students here are eager for modern education, the administration is hard pressed to cope with the difficult situation. The deputy director of the University, Mr. Ziauddin, listed a number of problems confronting the administration. There are not enough trained teachers and the university is badly short of printed materials.

The Balkh University was set up just a decade ago under the reign of Dr. Najibullah, who was brutally murdered by the Taliban after the fall of Kabul September last. It has 6,000 students now and seven faculties. But many more students are desperate for admission. The shortage of accommodation, trained staff and inadequate laboratories force the university to deny admission to many. Reflecting the generous outlook of the Afghan people, Balkh university has on its rolls about 15 Pakistani students. The Pakistani boys say they are treated well here.

The faculty of the University is desperate for external assistance to meet the challenge of higher education in northern Afghanistan. It is craving for a printing press of its own to produce text books for the students. Balkh University has established some linkages with Humboldt University in Germany and Kuni university in Turkey. The first batch of teachers are all set to go to Turkey for training.

Denial of education to girls and the bar against women to go out and work are among the many excesses that the Taliban has imposed on the people of Afghanistan in the areas under its control. Over the years in Afghanistan, women have formed a big chunk of the teaching community. By banning women from teaching, the Taliban has struck a devastating blow against schools in Afghanistan. 
In contrast, women's groups are working hard in northern Afghanistan to promote education among children under difficult conditions. Close to 50 per cent of enrolled students here are girls. And most of the teachers are women. But the shortage of buildings, books and stationery constrain this effort. With a prolonged civil war enervating the Afghan economy, there are barely any resources for education.

Asked what they will do if the Taliban takes over northern Afghanistan, the mood of the women alternates between sorrow and anger and between defiance and dejection. Ms. Hamira, who teaches law at Balkh University and is a member of the human rights commission here, demanded to know: "Where is the United Nations, when our women are being trampled upon? Why is no one in the world interested in our fate? Please write in your papers that our sisters in southern Afghanistan have lost all their rights".

Ms. Omana who teaches at a school here asserted, "We are ready to defend northern Afghanistan, at any cost, against the Taliban. We now have a life here to preserve". But behind that defiance, there is perhaps an unspoken realisation that if and when the Taliban runs over northern Afghanistan, there may be very little the Afghan women can do.

For two decades, Afghanistan women have paid dearly as their nation got caught in the crossfire of great power rivalry. They have lost their brothers, husbands and sons in a war that does not seem to have an end. Now they have been forced to surrender their basic human rights.

The initial hostile reactions of the Western media against the excesses of the Taliban did raise some hope that international women's groups will rally to defend the rights of their sisters in Afghanistan.

But there is an attempt in the Western media to repackage the Taliban, present it in favourable light before Western audiences and lend it legitimacy. Last month, representatives of the Taliban were serenaded in Washington and New York. It is being suggested that the West can do business with the Taliban, which could be slowly encouraged to moderate its social policies. With powerful geopolitical interests behind the Taliban, the prospects for international activism on issues of gender and education in Afghanistan do seem rather bleak. For now at least, the Afghan women here may have been condemned to mourn all alone.

\section{$\begin{array}{lll}\text { AFGHANISTAN NEWS SERVICE - News } & \begin{array}{l}\text { From C. Raja Mohan } \\ \text { Hindi Online }\end{array} & \text { March 22, } 1997\end{array}$}

\section{Immorality in Afghanistan}

$\mathrm{M}$ ANY aid organisations in Kabul have suspended their programmes after the arrest of two French aid workers by the Taliban, the Afghan capital's new rulers. Some are wondering whether to pull out altogether.

Most of the problems facing the aid workers concern the Taliban's attitude to women. The two Frenchmen and five of their local staff were arrested at a lunch party on February 21st given by the female expatriate staff for their Afghan women workers. The fate of the local staff is not known, but the Frenchmen are under investigation for what the Taliban consider immorality: being in the same compound as unveiled women. The veils they insist upon have a small patch of gauze covering the eyes; Saudi-style veils, which show the eyes, are unacceptable.

The Taliban are demanding that aid organisations buy mini-buses with curtains to transport their female staff. Local drivers are afraid of carrying women workers-whether expatriate or local-in case they are stopped by armed patrols and accused of immoral acts. Almost half of Kabul's mother-andchild health clinics run by aid workers have suspended their operations.

At first the Taliban, who occupied Ka- bul in September, turned a blind eye to the fact that many Afghan women were working for aid agencies. Since the arrests, the agencies have sought written guarantees that their work will not be impeded. The Taliban will not give them.

Even if they would, the guarantees would not necessarily be honoured by street patrols. There is a big difference between what is decreed by those supposedly in authority and what happens in reality. The Taliban have said that women are allowed to work in medical services, subject to certain restrictions. Yet cars carrying women to and from work have been stopped, the drivers harassed and the women ordered home.
A pull-out by aid agencies would be a serious blow to Kabul's citizens. International organisations provide more than $90 \%$ of medical supplies in Kabul, and almost half the city's population receives some kind of food aid. 


\section{Bread is precious in the City of Widows}

\section{By Esther Robinson}

K abul, Afghanistan - It's winter in Kabul, a pretty city situated in the mountains at 6,000 feet above sea level. Evergreens grow along the roadside, the sky is a deep blue and the sun shines on the snow-covered summits. The alpine climate makes for pleasant summers - hot but not humid - while winters are harsh and cold.

In this musing, it is almost possible to forget the reality: that this is Kabul after almost 20 years of continuous war, where 1 million residents endure rampant inflation and few job prospects. Many families live in abject poverty in somebody else's house because their own house and all their possessions were lost in a bombing raid or a rocket attack.

Theirs is a tough life and, with the recent takeover of the city by the Taliban, the lives of Kabul's citizens have been changed again. The Taliban, a group of fundamentalist rebels, banned women from the workplace. Some of Kabul's women are educated to university level - like many of us, they strive for meaningful careers. To have all of this taken away almost overnight - has left them angry and confused. But the women who are suffering most are the war widows of Kabul.

Kabul is called the City of Widows because it is home to 30,000 women who have lost their husbands in the war. Many of them are displaced from nearby rural areas and, coming from more traditional families, are poorly educated. When their husbands were alive, the women were responsible for managing their households and bringing up the children while the men worked to provide for the family.

Now, the women are forced to earn an income in a city where women have been banned from the workplace. Because they are unskilled, many beg.

Others knock on doors and ask whether they can do household chores in exchange for just enough to buy a bit of food.

The prices are still too high for many people to afford enough to eat, and during the winter they must choose between heating or food. Usually they choose food and eat their meals in freezing houses. Cooking fuel consists of old paper, dry leaves and old plastic that the children have scavenged that day.

As I walk around the city, women and sometimes old men approach me with their cloth bread bags open. They ask for bread and tell me that their children haven't eaten for two days. They move from street to street knocking on doors and asking for leftover food or day-old bread.

Two cute little girls, about 3 and 5, approach me outside a friend's house. Their outstretched hands need no explanation. As they stand shivering in six inches of fresh snow, wearing broken plastic sandals and a thin summer jacket, the oldest tells me that her father is dead and her mother is sick.

In my work, I come face to face with the way ordi-

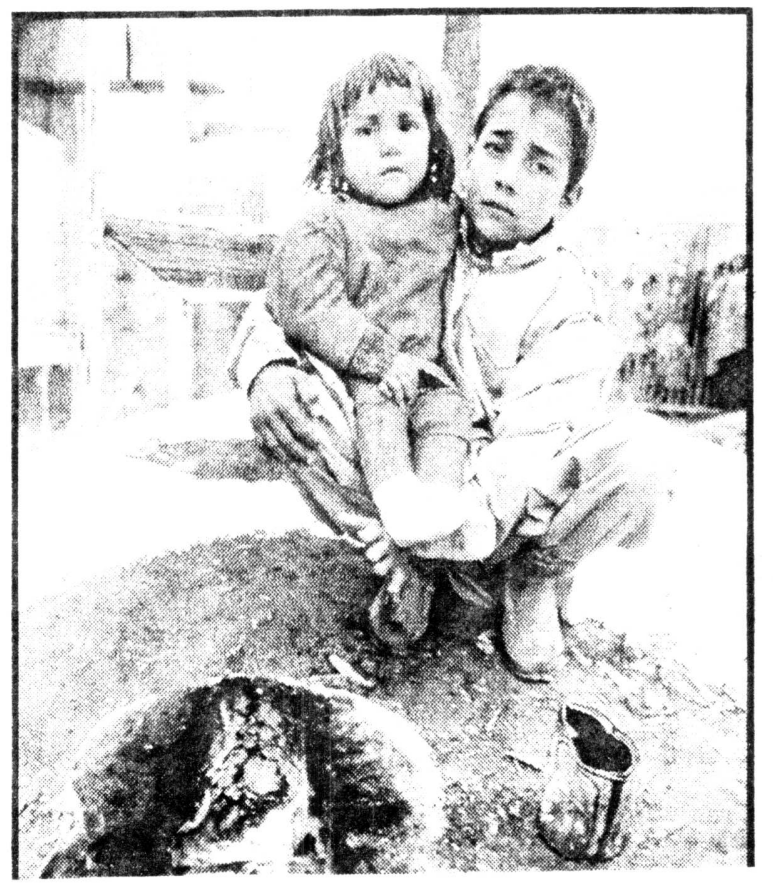

nary people have to live, knowing that they have little opportunity to improve their lot. I stand in the door: way of their homes and feel the freezing cold from the mud floor seep onto my feet and work its way up my legs. At the end of the day, I return to a sparsely furnished but warm house and a full, if simple, meals

Many people are being helped. CARE provides 10,000 widows - a third of all the widows in Kabul with winter staples of bread, lentils, red beans and vegetable oil. I manage a project where widows sew " or knit clothes and blankets, which are sold to otheragencies to be distributed as relief items. The profit earned is used to buy more materials. Instead of wag̀ es, the widows are paid in food for all the items they: produce. The project had been shut down by the Tali: ban; delicate negotiations with Kabul's hard-line new rulers only recently enabled it to restart.

All of us at CARE worked over the recent holidays. The Afghan people accept Jesus as one of their prophets, but they don't celebrate his birth in the way we do at home. Thus, CARE made its regular food distribution on Christmas Day. The closest thing to Christmas in Afghanistan is February's Eid, whent, under normal circumstances, families visit and try to outdo one another in their offering of the best cookies and cakes. In normal times, everybody would buy new clothes and the children would receive sweets, shoes or money from relatives.

But on this Eid, as for the past 20 years, the Afghan people will have little to celebrate.

The holiday will merely serve to invoke the memories of happier times for those who can remember that far back, and will be a time for the children to listen to tales of better days.

It is a new year in Afghanistan. Let us all hope it is a better one for its people. 


\title{
Taliban authorities promise protection
}

\author{
Vinety percent of former displays scattered
}

ONDON. Heroic elforts are be ha made to save what remains the Kabul Museum, once the inest in central Asia. Most of important pieces have been oted during the past our ars. But with conditions worsning, an unpublicised rescue eration was mounted in Sepember to move what survives rom the vulnerable museum uilding on the outskirts of Cabui to the comparative sate-

of the city centre. The art ewspaper can reveal that the arefully prepared evacuation ad aimost been completed hen the taliban seized power the capital on 27 September. The remnants of the collecon are now in specially proected rooms in the Kabul Hoi. Its lobbys has been convert d to a secure store for the thous carved wooden grave et gies from Nuristan. The large lining room was bricked in. nd steel doors removed from he museum have been used to reate smaller stores. Nine bedroom serve as offices.

The fate of the Kabul Muse$\mathrm{am}$ is a chilling reflection of Afghanistan's tragedy. The country'c cultural history is among the richest and most incient on earth, because of its trategic position on the crossroads of Asia and the West. Yet $n$ the space of just a few vears. o much of its heritage has been ost.

f the seventy masterpieces ustrated in the 1974 Kabul luseum guidebook, fifty-six ave been looted and the fate of ome of the remaining fourteen uncertain.

Most of the collection has lready passed onto the black market, dispersed to thousands f unscrupulous dealers and ollectors abroad. When the loor eventually reaches the connoisseurs, through a series of hands. prices are high. A specialist we spoke to in Islamabad revealed that she had just been shown urfirst-century Begram plaster medallions from the muse$\mathrm{m}$, with an asking price of $\$ 150.000$

The Kabul Museum, which is six miles south of the city in Daralaman, has been on the front line between competing Mujahideen factions. Control of Darulaman has constantly thanged hands since 1992. The nuseum has suffered a series i rocket attacks and has been oted dozens of times. despite Durageous efforts by statf to rotect the building and its preious contents.

of the seventy masterpleces ilustrated in the 1974 Kabul Museum guidebook. Ilfty-six ave been looted and the fate of some of the remaining tourteen is uncertain.

Most of the collection has arready yassed onto the biack market. dispersed to thousands if unscrupulous dealers and collectors abroad. When the loot ventually reaches the connorseurs. through a series of hands. rices are high. A specialist we poke to in islamaoad revealed hat she had just been shown our first-century Begram piaser medaliions from the museim. With an asking price 150.000 .

The Kabul Museum. wnich six miles south of the city in Daralaman. has been on the front line between competing Muiahideen factions. Control of Darulaman has constantly nanged hands since 1992. The museum has suffered a series of rocket attacks and has been looted dozens of times. despite courageous efforts by staff to rotect the building and its precrous contents.

Of the 750 obiects which had been on display in the museum intii its closure to the public in 992. probably ninety percent auve be a looted. Around half he many thousands of lesser pieces in store have disappeared. These estimates were given to the Art Newspaper by Carla Grissman, an American who until September was he Kabul representative of the Society for the Preservation of Afghanistan's Cultural Heritage

Earlier this year museum staff decided that it had become essential to move what remained of the collection to the centre of Kabul. Possible sites were examined and the Kabul Hotel was chosen, a large tnreestorey building constructed by the Soviets in the 1950s. Closed as a hotel several years ago, it lay largely abandoned, stripped of its furnishings, partly damaged by a nearby ordnance explosion, and with all the windows blown out.

The entire right wing of the hotel was rented to the Ministry i Culture and in June, ork tarted on converting it into a ries of museum storerooms. All the windows were bricked p, except for small spaces to Alow a little light to enter there mormaily no electricity in Sabui).

Meanwhile at Darulaman the ong process began of registerhg and packing the remaining bjects. Since the museum torerooms had last been put in rder in July 1995, they had ilfered yet again. The floors ere ankle deep in broken potery artefacts. Sorting through hat remained of the collecton was a painful process

\section{Dispersed}

1 The precious ivory throneack from Begram was lound emolished. atter boters had moved the thirteen intricatearved panels. Splinters of he throne were strewn on the loor. Countless fragments of mashed Greek plaster medallions were swept up from the Begram storeroom. Not a single intact object survived from the Begram collection, which had been excavated in the $1930 \mathrm{~s}$ at the second-century summer nalace of the Kushan king.

I The third-century $\mathrm{BC}$ marble herm figure from Ai Khanum was found headless, but the broken head was later disvered in another room

1 Many stone inscriptions from he second-century Surkh Kotal mple complex were sate. but Il the ornately carve Corinthian capitals had been looted. $\sqsupset$ The important schist figure of a worshipping child from Paitava had gone (second to fiftin century). All that remained as apathetic solitary fragment. the bov's left hand holding : bowl.

\lrcorner The Islamic bronzes and lusterware from Ghazni. dating form the tenth to the thir teenth centuries, had been maindestroved by fire.

\lrcorner Virtually the entire collec tion of 35,000 coins had been looted including the largest known Greek coins, part of the Kunduiz hoard). In the sand near the entrance to the museum a single second-century Sasanian coin was spotted.

$\checkmark$ The fifteen carved wooden figures and grave effigies from the nuristan vere undamaged. Some of the woden
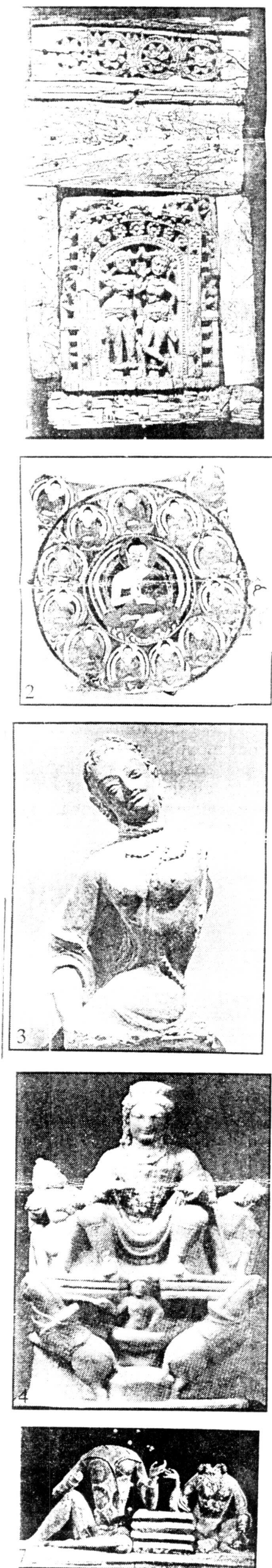

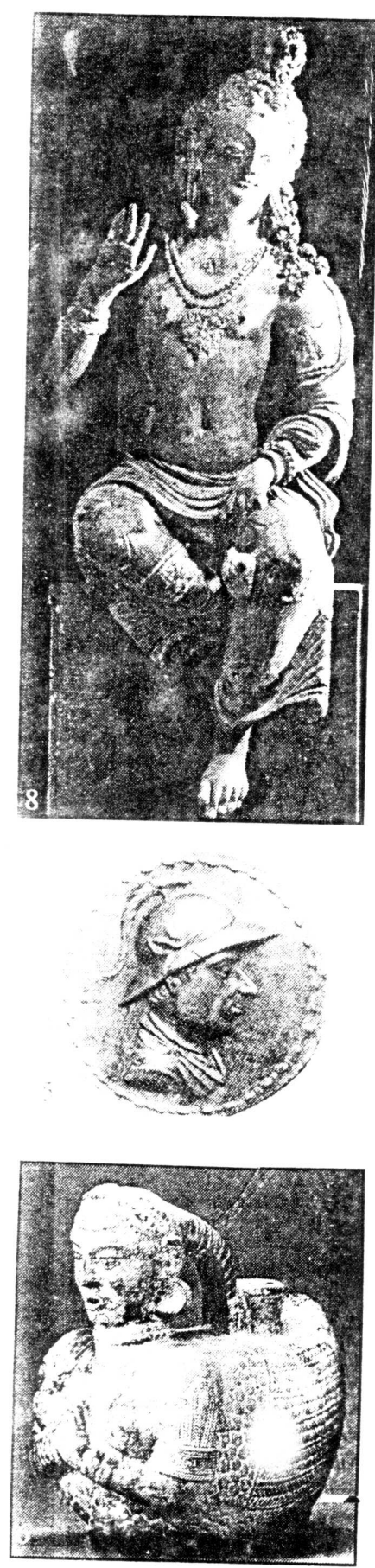

Nuristani pieces from the ethnographic collection also surived. although many of the culptured columns, chairs and door panels had been chopped up and used as firewood by guards posted to look after the museum.
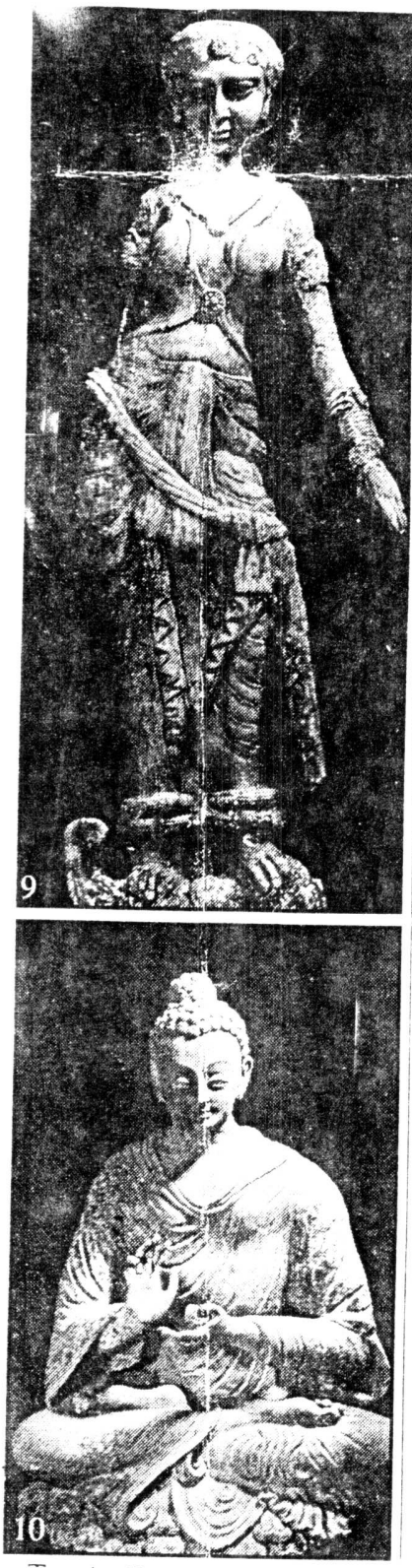

Tragically, the vast majority of what remained was fragments. Registration and packing took place in one of the basement storerooms under kerosene ilght (a generator provided by the UN had been stolen a few weeks earlier by guards

It was a slow process, taking from 22 April uncil 31 August. Altogether, a total of $3.311 \mathrm{ob}$ jects were registered ( 771 of which were photographed

The museum staff worked rolcally unde

Presham and his deputy

ibullah Popal. Wh

Popai recerved sil.

rom Kathut in the decreput bus

als dangerous. Ther

quent shelline and

dong the roidand perineponece

week the museum bus

arned at the last minute net

\section{make the trin. On}

carly July

in an attack

It was not much sater onee

statf reached Darulaman. On 18

August the museum to

rect hit from! a Taliban rocked. which tore a three-foot hole in the roof and hit the reconstructed twelfth-century mosque of Lashkari Bacer. The shattered wooden beams of the museum

ceiling fell onto the floor of the mosque, but fortunately with no serious damage to the fragile plaster wall panels. The ultrafundamentalist

ired that rocket will probably never know that it ended up desecrating an historic mosque.

Moving the collection started on 1 September, on an exposed tlatbed truck provided by the Darulaman zarrison with six armed men from the special police serving as guards. The final run from Darulaman to Kabul was on 8 Suptember. The following day the evacuation had to be called off because of in creased sheiling and rocketing It was hoped they could resume the operation, but fighting in tensified. leading to the Taliban takeover on 27 Sentember.

$$
\text { Altogether, a totat }
$$

oxes and 258 larger tems had been evacuated. representins nearly eighty-five percent of what had survived in the museum. Remaining behind at Daru laman are a small number of very large works (which would be more difficult to moves and less important smaller items.

In addition to what was evacuated from Darulaman in September, four other parts of the museum collection were removed for safety at an earlier time.

\section{Watch out: these goods are hot}

Ivory plaque, from Begram, first or second century AD 2. Mandala painted on clay, from ne of the Kakrak cave chapels, about $600 \mathrm{AD} 3$. Painted clay bust of the goddess Devata. om Fondukistan, seventh century 4. White marble carving of the sungod Surya, after 241

iI) 5 . Head of a double decadrachma coin of Amyntas, from Kunduz 6. Human-headed bird e in green glazed pottery, from Begram, first or second century A 9 7. Painted clay statue "the Princely couple", from Fondukistan, seventh century 8. Clav figure of Bodhisattva. im Fondukistan, seventh century 9. Ivory yakshis or river goddestes, from Begram, first cecond century AD 10. (lay Buddha with traces of polychrony, from Fondukistan. enth century. tored in Afghan

government buildings: aved?

The Tella Tepe treasure of

22,000 pieces of Bactriangold

dating from the tirst centur

3C. excavated with the

oviet archaeologis

In 1989 it was packed into

aults of the presidential pit

ace. Although the parace

famaged in the fighting

or official of the Ministr

Culture gave private assuran

in mid-September that the ella Tepe gold is

\lrcorner Gold and silver coins from the tepe Maranjan hoard, dat

ing from the fourth century and

tiscovered in a Buddhist mon-

astery. In 1993 this treasure wa

leposited in the

Central Bank. The governor

the bank gave an assurance in

ariv September that the treas

we is still there.

\lrcorner Ubiects sent to th

Culture in 199? some

bjects including Fondukistan painted clay sculptures of the venth century.

or safckecping io he mo

uilding in central Kabul

smaller works placed into twen

trunks and ethnogranic ma-

erial, were also moved. In ear-

1995 Ms Grissman

hown the sealed trunks. She

Iso saw ethnographic material umped in an adioining office.

ith dusty piles of clothing arved wooden pillars and lin

els from Nuristan, some brassare and an few antique cuns.

- Islamic miniatures (fifteenth to eighteenti entury and illuminated 0 rans

moved to the National Arch

the centre of Kabul in

They are presumed sate.

When the capital changed hands on 27 September all sixteen guards at the Kabul Hotel tled, to be replaced by Taliban fighters. The new Taliban Minster of Culture Mullah Akbar Khan Mutaqi has since given issurances to the society for the

Preservation of Afghanistan Cultural Heritage that the remaining collection there will protected, but others are not contident.

Meanwhile the fighting coninues outside Kabul. Air at lacks have been launched on he capital. Last month. Robert Knox, Keeper of Oriental Antiquities at the British Museum. echoed the thoughts of so man of his colleagues: "The Kabul Museum is of global imporance. I weep for Afghanistan and the museum". M. Bailey 


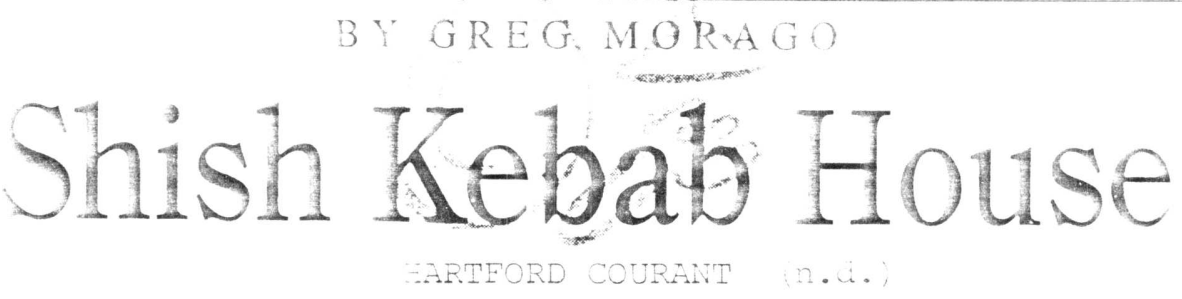

A shish kebab has always struck me as arty man's first significant gastronomic lear. Think if bored cavemen, weary of chomping on berries ind branches, experiencing their first curious taste f some wild boar caught in prehistoric fire. After urning his furry hand, our ancestor decides that tucks can be used to hold quivering meat to unamed flames. Voilá! The shish kebab is born.

Even today, there is something fabulousiy anient and almost cartoonish about the idea of grilled neat clinging to long shewers. If your idea of shish cebab recalls camptire weenie roasts, you 11 be iilrevared for dining at Shish Kebab House of Afghanistan. There is nothing comical or theatrical about the presentation here. In fact, the meals are elegant (and not a gleaming sword in sight; though the shish kebab entrees are cooked on metal skewers. the meat is removed before being served).

Dining at this family-run restaurant is wonderfully soothing. The decor - in shades of muted yellows and sun-baked sand broken by anciful woven tapestries and ugs - has an inviting, caiming effect. And the food plays on our most basic instincts to be warmed and well fed. The owners (Mousa Amiri runs the restaurant with his wife Najola and brother Kareem) certainly ensure the latter with meals that are as pretty as they are delicious. Flavors

bab-style is sliced into long, fat-slicked coins. Kebabbed shrimp remain juicy and sprightly, glistening vroudly in their garlic and lemon rub. Ditto for the tender chicken breast. Of the shish kebab dinners. lamb chops are the most desirable: two baby chops whose marvelous, roasted flesh gives way to tangy. pinky-red interior.

Dinners were served with fluffy brown rice of spinach-stoked white rice and a choice of vegetables. On both visits, our vegetable options were potatoes (reminiscent of the Indian dry-roast potatoes) in a vivid tomato sauce, roasted slices of eggplant drizzled in a garlicky yogurt sauce, and an unforgettable puree of pumpkin laced with garlic, cumin and cinnamon. Long after our visits. we're still talking about the velvety pumpkin mash.

Appetizers proved to be an PHONE: (860) 296-0301
HOURS: Dinner only, Mon.-Thur., 5-10 p.m., Fri. and Sat., 5-11 p.m. Closed Sun. PRicEs: Appetizers, \$2.95-\$5.95; entrées, \$9.95-\$14.95; desserts, $\$ 2.99-\$ 3.29$.

HIGHUGHT: Char-broiled kebabs of beef, chicken, sausage and shrimp are best bets. Don't pass up the lamb chops, the noodle appetizers and the soups.

SCENE: Clean, cheerful colors in a comfortable dining room. Good-natured service.

OTHER: All major credit cards; reservations accepted: full liquor; steps into restaurant (no ramp) but bathrooms are wheeichair accessible; cnildren's menu; takeout available.

Ratings primanily reflect food, with consideration given to service and ambiance.

$$
\begin{array}{ll}
\xi=\text { poor: } \quad \star \text { fair, } \quad \star \star \text { = good; } \\
\star \star \star \text { = very good; }
\end{array}
$$

here touch on Indian and Middle Eastern, employing ingredients like raisins, garlic, ginger, pistachio, almonds, lemon and yogurt; and herbs and spices such as mint, coriander, cinnamon, cumin, clove and nutmeg. But you won't find heavy gravies and tongue-scorching elements to this cuisine; spice combinations may not be simple but they are judicious, enhancing where they must, allowing true llavors to shine through where they should.

That is most evident in the basic shish kebab dinners that constitute the majority of entree options. The basic beef kebab deserves its place at the top of the menu. The char-broiled cubes of tenderloin are liberally speckled with black pepper and drenched in lemon juice. The tongue first picks up a peppery pucker but chewing immediately releasthe rich beefy juices. Beef sausage cooked keunexpected treat. Thin, delicate noodles figured in several cunning starters. A dish called mantoo featured purses of steamed noodle holding minced meat and scallion and topped with stewed yeilow peas and yogurt sauce.

A similar preparation called ashak held many of the same flavors but in a more looseiy interpreted, lasagnatype presentation containing chopped spinach. Both were fascinating and wickedly good. Thin sheets of noodles filled with finely chopped potatoes and meat (called bowlani) were crisped on the griddle, and resembled a crunchy flatbread. Samosas recall the Indian version but here the bundles are bound in a lighter pasta dough instead of a pastry dough.

Char-broiled ground beef kebabs make an excellent starter - moist and nearly fluffy tubes of tasty meat that has been liberally seasoned with sait, pepper and parsley. We loved the elephantear-sized slices of deep-fried potatoes dipped in a salty batter. Giant potato chips with a twist. Two soups will blow away the winter chills: a subtle pink pea soup and a fabulous brew holding squiggly noodles, spinach. ground meat and beans.

The owners are planning to expand the menu with more fish and vegetarian offerings soon. The news only makes a visit to this temple of Afghan cursine even more necessary.

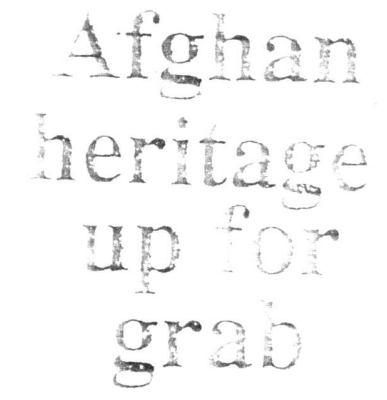

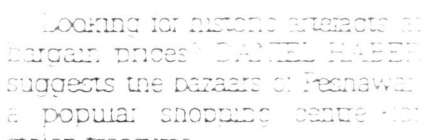

toines treasures

TIS IIS: 19 :

scuprure wers

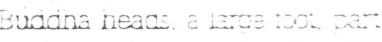

stone studi

seated Bucdizas

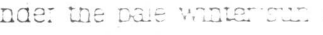

tae courtrar

iesnawa.

Inainc.

Takistan

tameez warns sien

zrres allowez

atre stuca we

ectrerv entroed :-n: :

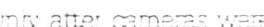

away cut Iraing and dicme

naul out the diece de resprands

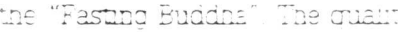

Oi Its vormansulp amos. nvals

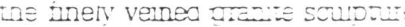

If the ianore Museum mancere

to pe the pinnacie ci Geminara a-

The pnce taz " Car $20.000 \mathrm{ca}$

las A Darcan Io: 2:0-1eacue a

jeale:s $" *$

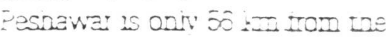

Atanan Doraer turouar the InvDe dass.. Sinee the couadse o: tre communis. regrme - and bna $2 \div$

tore dne Taledar miná wor. ove: Kaoul - vanous zuiandaee: fous nave peen sistematua." loonnd the kabu. Museur. paceless treasures : : wan ena

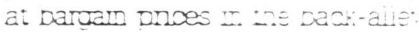
Dazaars of Posnawa: Lane: Nox.

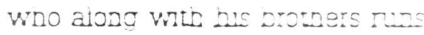
one o: the many Arnaz nana.

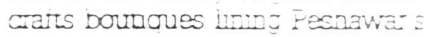
main Saca Bazaar. savs Haung :smuggled art botn trom Swat and trow the Kabu hiuseum is ate

Ar ceaiers are rouzher. cauct.

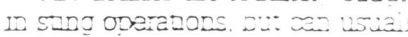
Duy thes wav out

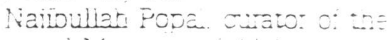
liagonal Musoum c: Linnaniszaestmatos Ina: apou. Th ser cea: ro Museums wlieras: naz has:

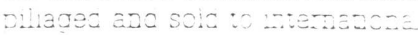

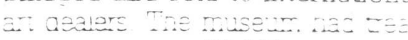
sures soanneg 50.005 vezs. … mos: vauade o: Wnach was ze: nads the priceless. $=\cdots:$ : 20\% in bactian goid. it as deveved to na:

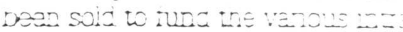

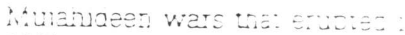
192- an a:e still reas.

rontier Post $3 / 10$ 


\section{Afghans Under 16 Commandments}

The Islamic rulers of Afghanistan, a.k.a., Talibans, have lately announced 16

By Ghafoor Zafari commandments to regulate civic life in the country by outlawing activities of leisure, habits of lust, laxity of morals, and lapses of modesty among errant Afghan men and women. The 16-commandment code of civic behavior has been enforced by the National Director of Culture and Public Services, Mullah Inayatullah Baleegh. I am sharing the details of this code with your readers to contrast the West that is struggling for "the last civic right to die" with the East where millions of Afghans are still struggling for their "first civic right to live." Here are the Sixteen commandments:

First, women clad in Iranian-style Chador to veil themselves shall be considered too immodest to be driven in private or public vehicles. If drivers were found to be driving such immodestly veiled women, they would be arrested.

Second, sale and play of audiotapes (of music) shall be banned. Businesses dealing in such

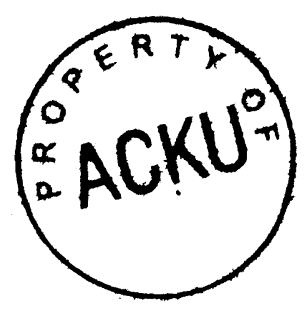
sales shall be closed down, public vehicles outfitted with such tapes impounded, and their drivers arrested.

Third, beard-trimming and beard-shaving shall be punished with confinement until the violators have grown their trimmed or shaved beard to the standard size.

Fourth, fifteen minutes before each prayer call, that is made five times a day, all adult men shall cease their daily business and rush to mosques. Violators shall be arrested forthwith.

Fifth, bird-keeping shall be considered frivolous, and keeping of birds such as pigeons and quails shall be punished with the confiscation and slaughter of the keep.

Sixth, buying and selling of liquor shall be banned. Violators shall be arrested and punished. Business stores selling alcoholic beverages shall be shut down and destroyed.

Seventh, kite tlying, and betting on kites shall be outlawed. Violators shall have their kites confiscated and destroyed.

Eighth, arts such as photography, drawing, and painting shall be considered idolatry, and as such outlawed. Public display of photographs, pictures, and paintings shall be banned. Violators shail be arrested anci punished.

Ninth, gambling shall be outlawed and gamblers sentenced to one month in jail.

Tenth, wearers of pony tails in Anglo-American style shall have their heads shaved on their own expense.

Eleventh, financial transactions such as money changing, and interest on loans shall be banned.

Twelfth, adult women caught in the act of washing household laundry in public places, such as rivers, brooks and streams, shall be considered immodest, and have their husbands arrested for lack of vigilance.

Thirteenth, dancing, singing, and instrumental music shall be outlawed at weddings. In the case of violation, the hosts shall be arrested and punished.

Fourteenth, drumming (of beats) shall be considered un-Islamic, and as such preached as unlawful.

Fifteenth, young adult women shall be disallowed to visit tailor shops, watch fashion catalogs, or have their measures taken by the tailors. In the event of violation of any of such prohibitions, tailors shall be arrested.

Sixteenth, witches shall be imprisoned until they repent, and books of witchcraft shall be burnt down. 